Ricardo Roclaw Basbaum

\title{
Você gostaria de participar de uma experiência artística? (+ NBP)
}

Tese apresentada ao Programa de Pós-Graduação em Artes Visuais, Área de Concentração Poéticas Visuais, Linha de Pesquisa Processos de Criação em Artes Visuais, da Escola de Comunicações e Artes da Universidade de São Paulo, como exigência parcial para obtenção do Título de Doutor em Artes, sob a orientação do Prof. Dr. Martin Grossmann.

Programa de Pós-Graduação em Artes Visuais Escola de Comunicações e Artes Universidade de São Paulo

São Paulo 2008

\section{VOLUME 2}


Ricardo Roclaw Basbaum

\section{Você gostaria de participar de uma experiência artística? $(+$ NBP)}

Tese apresentada ao Programa de Pós-Graduação em Artes Visuais, Área de Concentração Poéticas Visuais, Linha de Pesquisa Processos de Criação em Artes Visuais, da Escola de Comunicações e Artes da Universidade de São Paulo, como exigência parcial para obtenção do

Título de Doutor em Artes, sob a orientação do Prof. Dr. Martin Grossmann.

Programa de Pós-Graduação em Artes Visuais Escola de Comunicações e Artes Universidade de São Paulo

São Paulo

2008

\section{VOLUME 2}




\section{Sumário}

\section{Volume I}

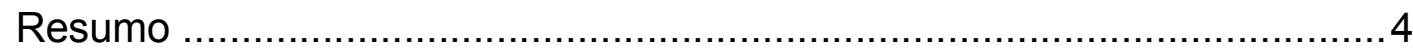

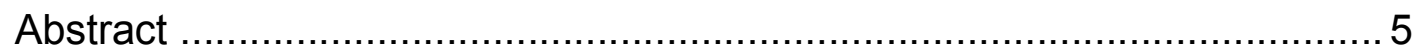

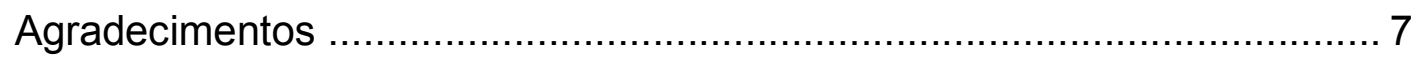

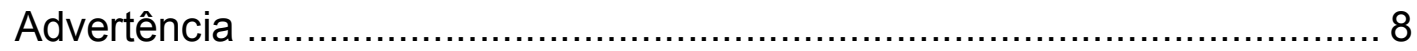

A: Künstlertheorie, Sistemas de revezamento plástico-discursivos ............15

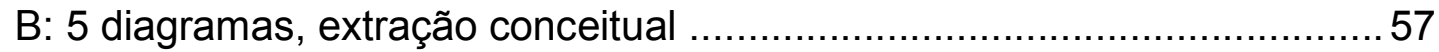

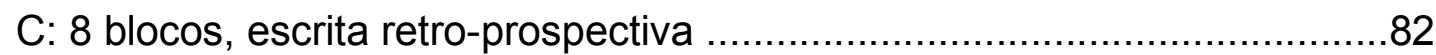

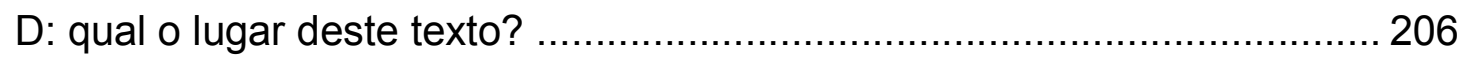

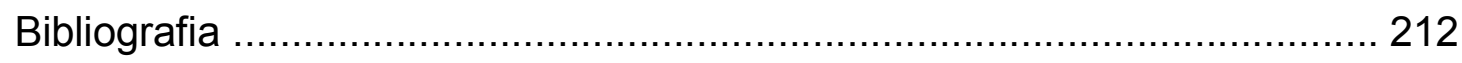

\section{Volume II}

\section{Anexos}

Você gostaria de participar de uma experiência artística? ....................... 5

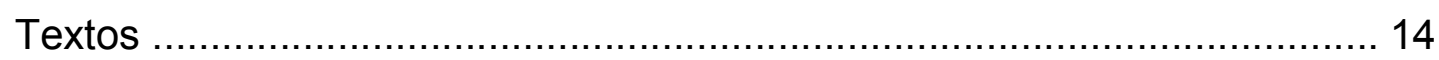

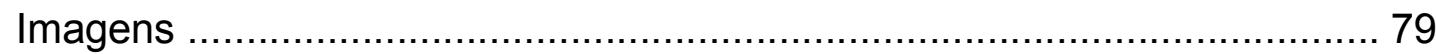


Você gostaria de participar de uma experiência artística? 


\section{Você gostaria de participar de uma experiência artística?}

Breve e sucinta descrição do projeto de trabalho Você gostaria de participar de uma experiência artística?, em suas linhas gerais, indicando as etapas através das quais o projeto se desdobra e desenvolve, desde seu início, em 1994, até a atualidade incluindo a instalação apresentada na documenta 12 (Kassel, 2007), que veio a ser a primeira apresentação pública do projeto em todas as suas etapas.

\section{objeto, circulação}

Você gostaria de participar de uma experiência artística? é um projeto acerca do envolvimento do outro como participante em um conjunto de protocolos indicativos dos efeitos, condições e possibilidades da arte contemporânea.

Você gostaria de participar de uma experiência artística? se inicia com o oferecimento de um objeto de aço pintado $(125 \times 80 \times 18 \mathrm{~cm})$ para ser levado para casa pelo participante (indivíduo, grupo, coletivo ou instituição), que terá um certo período de tempo (em torno de um mês) para realizar com ele uma experiência artística. Fig. 58

As decisões acerca do tipo de experiência a ser realizada, locais onde será desenvolvida e como o objeto será utilizado, dependem diretamente dos participantes. Todos os que participam de Você gostaria de participar de uma experiência artística? - seja sujeito individual ou coletivo -, desenvolvem experiências de livre proposição e escolha, movimentando-se em terreno próprio. Não é colocado nenhum limite ou fornecida qualquer instrução acerca do que deve ou pode ser feito - logo, a partir do momento em que recebe o objeto, este passa a ser de inteira responsabilidade do participante.

A única exigência que Você gostaria de participar de uma experiência artística? impõe aos participantes é que a experiência realizada seja documentada e os registros sejam enviados ao website do projeto - de modo que se tornem públicos. A documentação das experiências realizadas também é de inteira responsabilidade do 
participante, que deve decidir acerca do meio a ser utilizado e da maneira de realizar os registros. Assim, os participantes enviam os resultados de suas experiências sob a forma de textos, imagens, vídeos ou objetos, para serem disponibilizados em http://www.nbp.pro.br - cada participante tem acesso a ferramentas para edição própria da documentação enviada.

Ainda que o objeto físico seja o elemento real e concreto que deflagra os processos e inicia as experiências, seu papel de fato é trazer para o primeiro plano certos conjuntos invisíveis de linhas e diagramas, relativos a diversos tipos de relações e dados sensoriais, tornando visíveis redes e estruturas de mediação. Além de uma série de tópicos e problemas trazidos pelo próprio projeto - e portanto mobilizados diretamente pelo participante durante as experiências - Você gostaria de participar de uma experiência artística? toca em questões em torno da arte e da vida, abordando o relacionamento entre o sujeito e o outro, conduzindo diretamente a processos de transformação. Os participantes têm em mãos um instrumento para realização de suas próprias intervenções e proposição de problemas.

O objeto utilizado em Você gostaria de participar de uma experiência artística? tem sua forma estabelecida de acordo com o projeto NBP - Novas Bases para a Personalidade, um projeto em desenvolvimento contínuo compreendendo desenhos, diagramas, objetos, instalações, textos e manifestos, iniciado em 1990. O projeto NBP conecta práticas e conceitos da arte contemporânea a estratégias comunicacionais, associando-se com alguns dos recentes desenvolvimentos do campo das políticas da subjetividade. A forma específica NBP foi desenhada para ser memorizada tão facilmente quanto sua sigla: ao experienciar qualquer trabalho NBP o espectador sai com NBP e sua forma específica em seu corpo, tal qual um vírus - são utilizadas estratégias de contaminação a partir da mobilização dos campos sensorial e conceitual. O projeto NBP busca deflagrar processos de transformação, na mesma medida em que assimila e incorpora transformações como resultado de sua própria história e processo. 
Você gostaria de participar de uma experiência artística? é claramente um projeto de trabalho-em-curso, e encontra seu modo de desdobramento no processo mesmo de seu desenvolvimento. Virtualmente, o projeto não apresenta qualquer fim imediato a curto prazo, uma vez que sua continuidade deriva diretamente da intensidade e do prosseguimento das experiências e não depende do tempo de vida do autor/propositor - o objeto é concebido como um múltiplo, e novos objetos podem ser produzidos sempre que se fizer necessário. Os objetos em circulação não devem retornar ao artista e portanto seguem um ritmo próprio de circulação através dos diversos participantes.

De 1994 a 2008, Você gostaria de participar de uma experiência artística? teve construídos e colocados em circulação um total de 23 objetos (o primeiro deles, um protótipo). Até 2006 haviam sido construídas apenas três peças, sendo que sempre houve um único objeto circulando de cada vez, na seguinte seqüência: o objeto protótipo circulou em julho de 1994; um segundo objeto, de 1994-1999; um terceiro (objeto clonado por participante), entre 1999-2006.

Com o convite para desenvolver a participação na documenta 12, o projeto Você gostaria de participar de uma experiência artística? passou a ser desenvolvido em uma escala maior: foram produzidos 20 novos objetos, distribuídos inicialmente em nove países de três continentes. Na Europa, foram enviados seis objetos para Kassel, na Alemanha; um para Liverpool, Inglaterra; um para Viena, Áustria; e um para Ljubljana, Eslovênia. Foi enviada uma peça para Dakar, Senegal, na África. $\mathrm{Na}$ América Latina, foi enviado um objeto para Valparaiso, Chile; um para Buenos Aires, Argentina; um para a Cidade do México, México; e sete peças para Florianópolis, Curitiba, São Paulo, Rio de Janeiro, Rio Branco e Fortaleza, no Brasil. Neste momento (maio de 2008), existem 18 peças em circulação em 8 países.

Até maio de 2008, estão registradas 107 participações, envolvendo diversos indivíduos, grupos, coletivos e instituições, em 37 diferentes cidades de 9 países. 


\section{website}

Desde setembro de 2006 o projeto Você gostaria de participar de uma experiência artística? desenvolve-se com apoio de website próprio, hospedado em http://www.nbp.pro.br, desdobrando-se pelo espaço informático-mediático como parte integrante da esfera pública contemporânea. A utilização da internet se dá enquanto área diretamente integrada à dinâmica do mundo, permeável aos embates sociopolíticos da atualidade. Tal traço é importante para este projeto na medida em que as atividades e ações realizadas em locais específicos, por participantes estreitamente conectados às suas áreas de atuação - sejam espaços de vida privada, comunitária ou institucional -, têm seus registros organizados em relação direta com a arena pública do espaço eletrônico, incorporando continuidades e descontinuidades entre os espaços presencial e virtual.

Além de funcionar como ferramenta de utilização direta para publicação e edição das experiências pelo participantes (organizado em forma de blog de atualização contínua), o site é composto pelo arquivo de documentos do projeto Você gostaria de participar de uma experiência artística? (apresentando textos, diagramas, folhetos de instruções), e por uma breve apresentação do projeto $N B P$, em conjunto com alguns documentos a ele relacionados. A página de abertura do site está desenvolvida através de programação dinâmica, que permite visualização do percurso de deslocamento de cada objeto pelos diversos participantes: os pontos na tela correspondem aos participantes do projeto; ao passar o mouse sobre cada um deles, um desenho em linhas azuis revela quais deste pontos estão reunidos em torno de cada objeto. Fig. 75 Assim à medida que novos participantes são incorporados a Você gostaria de participar de uma experiência artística?, novos pontos são acrescentados à página inicial.

As experiências estão indexadas por data, nome do participante e cidade de realização, indicando sempre o período correspondente ao início (recebimento do objeto) e fim (devolução do objeto à circulação) das ações. Na área correspondente a cada participante podem ser postados textos, imagens, arquivos de vídeo e áudio: 
cada participante recebe uma senha de acesso e assim pode organizar a documentação da maneira que melhor lhe convir.

Há ainda uma área aberta para desenvolvimento de comentários críticos ao projeto - ali, alguns convidados (artistas, críticos e escritores de diversas áreas) utilizam a escrita para tecer um discurso polifônico coletivo que contribuirá para a construção de um corpo crítico acerca de Você gostaria de participar de uma experiência artística?

Desta forma, o espaço ocupado na internet vai progressivamente constituindo o banco de dados do projeto - com documentação de todas as experiências realizadas, descrição do projeto e documentos relacionados - ao mesmo tempo que configura uma constelação polifônica na qual se percebem as vozes de participantes diversos: trata-se de um processo de construção de pensamento coletivo em torno de Você gostaria de participar de uma experiência artística? que assim vai sendo continuamente atualizado.

\section{instalação arquitetônico-escultórica}

Para apresentação de Você gostaria de participar de uma experiência artística? na documenta 12 - de fato a primeira apresentação pública do projeto em todas as suas etapas - foi desenvolvida uma instalação multimídia, na forma de uma estrutura arquitetônico-escultórica. Esta instalação oferece ao público visitante a possibilidade de acessar documentação sobre as experiências realizadas, a partir de navegação pelo website, da exibição de vídeos produzidos pelos próprios participantes a partir de suas experiências e da apresentação de uma seqüência de imagens de experiências na forma de slide-show. O aspecto arquitetônicoescultórico da instalação permite que o visitante ocupe tanto o exterior como o interior da estrutura. Fig. 70-73

A instalação arquitetônico escultórica que integra o projeto Você gostaria de participar de uma experiência artística? é construída em ferro, revestida com telas perfuradas também de ferro, formando uma estrutura compacta e resistente e ao 
mesmo tempo permitindo transparência, sem impedir que o olhar percorra o interior do espaço ou mesmo se desloque das áreas internas para o lado de fora. As áreas externa e interna são organizadas de dois modos diferentes, ambas porém oferecendo espaços para que o visitante se acomode: a parte externa é composta de duas arquibancadas, em que os visitantes podem se sentar; a parte interna é formada por duas salas forradas de carpete, oferecendo ainda colchonetes e almofadas para acomodação do visitante. As duas salas são divididas por uma porta vazada, permitindo a passagem através dos dois espaços. Assim, a estrutura como um todo permite o contínuo deslocamento entre o exterior e o interior. Um conjunto de oito câmeras de circuito-fechado está instalado por toda a estrutura, formando um conjunto de captação de imagens em tempo-real que conduz diretamente à área interna, dialogando com outras instalações da série sistema-cinema. ${ }^{1}$

Cada uma das salas da área interna está equipada com quatro monitores de 19", de modo a transmitir quatro diferentes tipos de imagem: (1) acesso online ao website; (2) compilação de vídeos realizados pelos participantes da experiência Você gostaria de participar de uma experiência artística?; ${ }^{2}$ (3) slide-show em DVD de imagens de experiências realizadas pelos participantes de Você gostaria de participar de uma experiência artística?; (4) imagens em tempo-real enviadas pelas câmeras de circuito-fechado (4 câmeras transmitem para o monitor da primeira sala, e 4 para o monitor da segunda sala). Dois pares de fones de ouvido, conectados aos monitores com o website e com a compilação de vídeos, permitem acesso ao áudio sem que uma transmissão interfira na outra. Dois teclados com mouse trackball, um em cada sala, permitem acesso ao website.

A estrutura externa da instalação é desenvolvida na forma de uma arquibancada, com 4 níveis - são oferecidos espaços para que os visitantes sentem-se para conversar ou olhar o espaço circundante. Além disso, a área em torno da estrutura

\footnotetext{
${ }^{1}$ sistema-cinema é o nome de um procedimento de captação, transmissão e gravação de imagens, em tempo real, que tenho utilizado, a partir de 2001, em conjunto com a construção de instalações, intervenções e objetos. Cf. Ricardo Basbaum, "roteiro para sistema-cinema". Texto escrito para o livro Transcinemas, de Kátia Maciel (Org.), inédito. V. Anexos, neste Volume.

${ }^{2}$ Existem até o momento (maio 2008) três compilações de vídeos realizados pelos participantes, perfazendo um total de 22 vídeos. Uma quarta compilação está em preparação.
} 
arquitetônico-escultórica está organizada com painéis sobre Você gostaria de participar de uma experiência artística?: são apresentadas informações conceituais, lista de participantes e o diagrama do projeto. Fig. 74

Assim, o visitante que percorrer o espaço da instalação terá acesso às suas áreas externa e interna: ao mesmo tempo que a própria estrutura arquitetônico-escultórica propõe um espaço a ser vivenciado pelo visitante, são oferecidos ainda elementos audiovisuais e informativos ali diretamente integrados. $\mathrm{Na}$ área interna, duas salas exibem documentação referente aos participantes do projeto, composta de registros das experiências realizadas; na área externa são apresentados painéis informativos e diagramas, além de se oferecer uma área para que cada visitante possa sentar-se e observar o espaço em torno. A acentuada demarcação dos espaços interno (salas para abrigo) e externo (arquibancadas), também se relaciona - em termos escultóricos - ao próprio objeto utilizado pelos participantes de Você gostaria de participar de uma experiência artística?: pode-se perceber a experiência de apreensão sensível da estrutura arquitetônico-escultórica como homóloga à experiência de utilização do objeto.

Existe ainda um detalhe importante na estrutura arquitetônico-escultórica de Você gostaria de participar de uma experiência artística?: um objeto, exatamente igual ao utilizado pelos participantes, está localizado em uma das áreas internas da estrutura, tendo seu acesso bloqueado por uma porta trancada à chave. Assim, este objeto está apenas disponível ao olhar através das grades metálicas - deve permanecer sempre ali, avesso a qualquer tipo de circulação, alheio ao toque. Desta forma se estabelece um contraste entre os objetos que estão em circulação por diversos países, disponíveis para a produção de experiências, e este, que integra, imóvel e inacessível, uma instalação em espaço expositivo.

A estrutura arquitetônico-escultórica de Você gostaria de participar de uma experiência artística? é peça que pode ser continuamente atualizada, de acordo com o prosseguimento do projeto: novos vídeos e imagens podem ser continuamente acrescentados. De modo que funciona concretamente como estrutura de 
armazenamento e conservação da memória do projeto (vídeos, imagens, website) uma certa modalidade de escultura-museu aberta a um duplo acesso por parte do público: tanto pode ser apreendida como elemento portador das informações sobre o desenvolvimento de Você gostaria...? como ser objeto de experiência estética, sensível. 


\section{Textos}




\section{OLHOS}

(1985)

é a questão, ou não

é a questão da pintura, da marca pessoal do artista

é a questão da comunicação de massa

é a questão da sociedade de consumo

é questão de colocar e juntar os objetos que existem por aí, em estado bruto

é questão de economia de meios

é questão do souvenir, comprado para presente

é a questão de estar em todos os lugares ao mesmo tempo

é a questão

é questão ou não?

é a questão

é questão ou não? 


\section{Caderno de Notas 1990/1991}

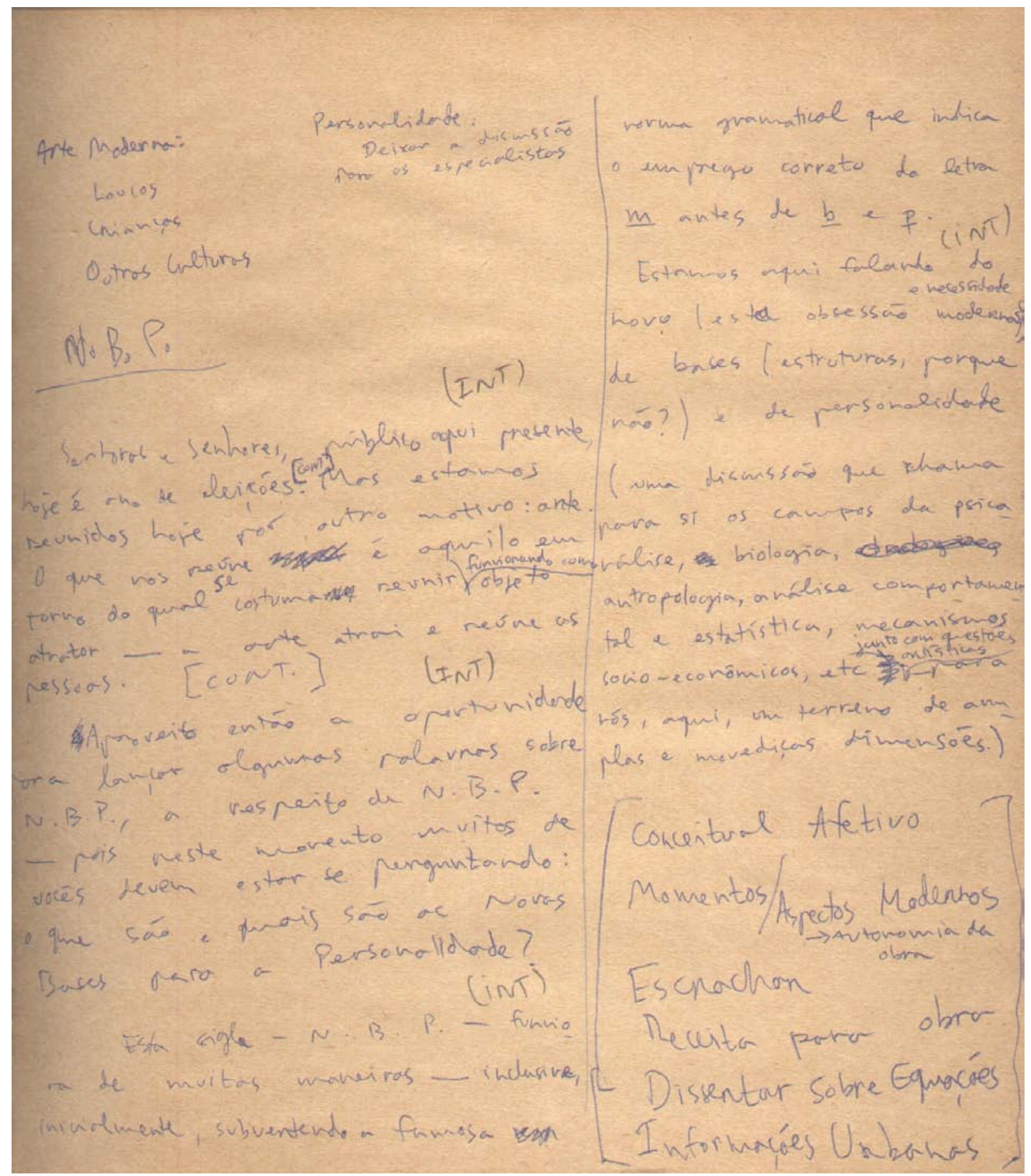


NB. P.

coteiro:

- escurita en forma de discunso, pronta para oralizacáo.

- SIGLA: o que é? o que sigmifica? (2)

Porque essas trés letras? Porque a forma de Maren?

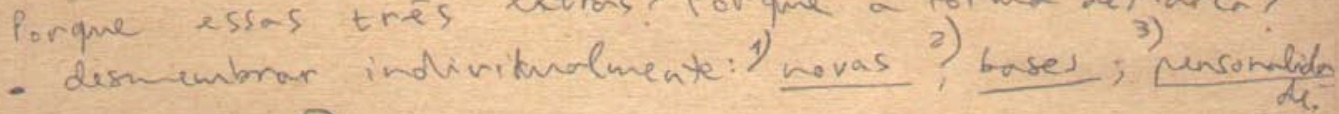

(CoNCL)

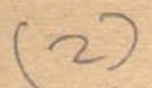

- NBP em objitos; em Rivros, neon, etc = motetiplas aplicacoès (chachá: caso especial; instrucoes como have de latura)

- A Literariedade do traballo $(1,2,3)$

- Afetividade (3)

- Asrectos modennos (1)

- srectos formais e estruturais ( 2 ): TEMPO, ESPACO

- Anélise do panorama = insencás Eńtica (INT)

- Projeto plastico (2)

Aspectos úteis interessantes e relevantes da ante contemporaineas

- dimensár conceituol ader comunicativolafetivo e.p (FNT, 2) (1)

- apreensáo de totalidates fenomendígicas: on site worls, reduncóla forma (minimolismo)

- campo ampliado

- Arálise de formulas. Fisicas, Quimicas, Matemáticas. (2)

$$
\begin{aligned}
& E=m c^{2} \text { (Ginstein) } \\
& s=k \log w \text { (Boltzman) } \\
& \text { Firmulas } \\
& \text { oLHO } \\
& \Delta M_{r}-M_{t} \rightarrow 0
\end{aligned}
$$




\section{O que é NBP?}

(1990)

o que é

NBP ?

é uma sigla, formada por três letras,

uma espécie de motivação geral ou pretexto

de trabalho (quase um programa para ações),

um meio para impregnação do espaço.

Quase um lugar-comum atópico.

\section{NBP}

impregna e contamina.

\section{NBP}

desenvolve-se através de três idéias-vetores principais:

\section{1 imaterialidade do corpo}

A matéria orgânica dissolve-se nos ritmos tecnológicos, na velocidade.

Corpos que podem ocupar muitos lugares no espaço ao mesmo tempo. Temporalidades que impulsionam espaços; espaços que configuram-se no tempo: continuidades e descontinuidades.

Nossos corpos transitando através destas oscilações.

\section{2 materialidade do pensamento}

O pensamento como algo que pode ser lançado, moldado, construído, acumulado, recolhido, contraído, expandido, amassado, jogado, corroído, revelado, ampliado, amplificado, estilhaçado, dissolvido, etc. O pensamento envolve as coisas - entre elas existe a atmosfera, com Oxigênio, Nitrogênio, Gás Carbônico, Enxofre, Chumbo, Alumínio, mas também partículas de pensamento. Estas partículas desprendem-se de nossos corpos-cérebros em fluxos além de nosso controle, aderindo aos objetos ou a outros pensamentos. Possuem campos gravitacionais e magnéticos potentes, que distorcem e alteram imagens todas as imagens das coisas. O pensamento é, portanto, essencialmente carregado de potencialidade plástica.

\section{3 logos instantâneo}

É o conhecimento visual: arrebatador, súbito, envolvente, imediato, instantâneo. Queremos nos instalar, pretenciosamente, dentro deste intervalo mínimo, no interior da instantaneidade - melhor dizer ao lado, mas do lado de dentro. Não como testemunhas, simples testemunhas oculistas, mas como estratégia para a geração de outros processos, múltiplos e variados, a partir deste lapso:

o intervalo de tempo entre meio emissor ( $\mathrm{Me}_{\mathrm{e}}$ - mensagem emitida) e meio receptor $(\mathrm{Mr}$ - mensagem recebida): 


$$
\Delta \mathrm{t} \mathrm{Mr}_{\mathrm{r}}-\mathrm{Me}_{\mathrm{e}} \rightarrow \text { Zero }
$$

\section{NBP}

é um programa para súbitas mudanças.

Quais? Como? Quando? Deixe-se contaminar: elas serão fruto de seu próprio esforço.

NBP

Novas Bases para a Personalidade 


\section{Dentre essas coisas}

Trecho extraído do livro "Novas Bases para a Personalidade", a sair pela Editora Incorpus, em 1991. Reproduzido com autorização do autor.

\section{$(\ldots)$}

Dentre essas coisas lançadas no mundo, aos milhões, que acontecem ser chamadas obras de arte, existem aquelas que apelam ao espectador, exigindo atenção, admitindo incompletude. Que provocam uma ginástica em nossa percepção; ativam mecanismos formadores dos sentidos; causam um fino estremecimento, reverberação, disritmia.

Essas coisas não são todas as coisas, são apenas algumas, com certeza as mais interessantes, pulsantes e ativas. Mas esta abertura de atuação não se acrescenta simplesmente ao objeto, assim como se adiciona sal ao alimento: o germe da inconclusão deve ser inoculado na estrutura da coisa, em precisos momentos de seu desenvolvimento - nos estágios de sua formação - para que se processe o adequado entrelaçamento entre presença, fluidez e acontecimento. Como resultado, a coisa surge já moldada enquanto incompletude, voltada ao movimento, impregnada, em diferentes níveis de sua estrutura, com dispositivos receptores e ativadores. Os primeiros, reafirmam continuamente o imperativo da autonomia (fundando para si lugar e território); os últimos, garantem transversalidade (afirmando abertura, transparência, trânsito para sentidos, significados, percepções).

Todo o problema, então, inicia-se, aparentemente, com um processo de inoculação e contaminação - seguido das etapas, tanto instantâneas quanto seqüenciadas, do processo de desenvovlimento ontogenético, sempre muito importante. É neste momento, precisamente, que as questões de escolha e decisão avolumam-se, obrigando a múltiplos (...) 


\section{roteiros}

(1992 - revisão 2007)

$1^{\mathrm{a}}$ volta

Estou dentro. Sei que estou. Caminho, passo por todas as partes, ando, percorro, subo, desço. Não há horizonte, não há frente ou trás ou direito ou esquerdo, apenas este espaço que percorro. Não há nada para ser visto e nem é possível enxergar. Talvez alguns traços de luz, mas nem isso, pois é muito pouco. Mas estas mínimas frestas permitem identificar um quase-desenho, um contorno, algo que desliza, onde eu deslizo, como espelhos ou verniz. Curvas seguidas de dobras, seguidas de desvios, seguidos de retas quebradas, seguidas de ângulos contorcidos, seguidos de falsos sinais, seguidos de impressões digitais, seguidas de grandes planícies. Quase não há luz, não é preciso, não há necessidade, pois este tipo de não-luz acolhe os passos seqüenciados. Muitas voltas iguais no interior da mesma estrutura, em torno do mesmo orifício, órbitas paralelas simultâneas simétricas não-lineares. $O$ fluxo percorre movimento ondular neste acelerador, movimento vertiginoso naquele desvio, movimento múltiplo naquela variante de repetição. Nunca as trajetórias se superpõem, nunca o rebatimento incessante deixa de indicar a aceleração positiva, mesmo se a permanência em torno do mesmo ponto implica em velocidade zero, mas muita insistência, e contante intensidade, e freqüente vibração, e conseqüências absolutamente imprevisíveis...

$2^{\mathrm{a}}$ volta

Ainda dentro, uma sucessão de retas, seguidas de curvas angulares. Duas retas mais longas, duas menores, quatro ainda mais curtas. O som dos passos, a escuridão, o silêncio, mais uma volta; respiração, outra volta, outro ciclo, insistência. Um tanto estreito este caminho, que no entanto repito. Um passo após o outro: não sou eu quem anda, mas o espaço dentro do qual caminho que se move. Enquanto este espaço se move, vejo pequenas bordas de luz, alguns poucos raios estriados, pequenos eclipses, como se formas se sobrepusessem às fontes de luz. A luz escapa pelas bordas. E este espaço que se move parece nunca repetir-se, como se 
eu andasse sempre em frente e o espaço sempre em ciclos. Como uma grande cápsula que se move flutuando por sobre outras cápsulas, que estão sobre outras cápsulas, rodeadas por outras cápsulas, imersas em líquido oleoso e viscoso, deslizando. Esta estrutura espacial é quem impulsiona, quem liberta a força do movimento, quem detona as outras forças: o espaço como estrutura-motriz, como impulsionador temporal, como figura topológica que exige o fim da força de gravidade para o início de sua existência. Quem?

\section{$3^{a}$ volta}

Desta vez em um tubo, longo, que se abre apenas por dois orifícios, um deles diretamente conectado ao espaço principal, a estrutura cujo interior é composto por esteiras deslizantes, onde ficamos de pé com a ilusão de estarmos parados, mas logo ressoamos em um conjunto em que tudo é movimento. Desequilíbrio. Mas esse orifício prolonga-se pelo tubo ao mesmo tempo em que promove uma possível conexão com seu interior; não sabemos. Com certeza é a configuração da possibilidade de atravessar: uma transversalidade, que é mais do que um corte, mais do que uma seção. O brilho indica a luz sendo atraída, mesmo no escuro. $O$ prolongamento trans-in-out-on-cross (trans-inverso-reverso) encurta as distâncias e indica um fim, que não é fim mas o local de outra conexão, indica novos receptores para a estrutura, estabelecendo seu raio de ação: a rede assim formada pretende irradiar-se por conta própria (é claro) mas também dissolver-se no invisível (é claro), como uma presença constante que pode ser ativada em qualquer tempo e em qualquer momento. 


\section{SUBLIME/SUBLIMINAR}

(1992)

Um novo funcionamento perceptivo, duplicado, em que dispositivos de texto e imagem atuam juntos, simultaneamente, como dois focos emissores/receptores de partículas sensíveis, ressonantes em diversas faixas de freqüência.

Texto e imagem plástica invadem a memória do espectador, instalando-se em seu cérebro, utilizando-se de seu corpo como veículo para deslocamentos no espaço e no tempo, numa estratégia de impregnação e contaminação.

Circuitos SUBLIMINARES ativam possibilidades de transformação, através (1) da SUBLIMAÇÃO dos limites e (2) da intensificação da plasticidade, como vias de acesso à instrumentalização do novo e a processos de complexidade e irreversibilidade do tempo, aproximando turbulência e ampliação de campo dos efeitos de valoração do SUBLIME. 


\section{(?)? Pergunta dentro de pergunta ${ }^{3}$}

(1996)

Boa noite a todos. Gostaria de aproveitar a ocasião para comentar junto com vocês alguns aspectos de meu projeto de trabalho, em progresso desde 1989, chamado NBP, que é a sigla que criei para a fórmula Novas Bases para a Personalidade. Preocupa-me neste momento fugir de um apanhado 'retrospectivo', para não lançar a conversa no passado; preocupa-me também a idéia de uma especulação voltada para o 'futuro'. Mas é certo que não escaparei aqui da oportunidade de fazer um balanço das ações realizadas nos últimos anos: balanço em aberto, junto com vocês - que têm acompanhado de perto muito do que mostrarei aqui -, que serão convidados explicitamente a intervir em tudo o que eu vier a colocar daqui para a frente, nesta conversa. Mas o principal desafio desta noite, creio, será lançar tudo o que tenho feito em uma atualidade, mostrar que as pesquisas aqui demonstradas pulsam junto aos nervos dos dias de hoje, participam desta vibração, produzem junto com as coisas que os outros aqui presentes fazem - reverberações decisivas e decididas.

Cabe ainda a pergunta, afinal, "o que é NBP?" ? (Não sei se puderam perceber, mas acabei de enunciar uma pergunta dentro de uma pergunta. Como responder a tal artefato sintático? Com uma resposta dentro de uma resposta?) Na primeira vez em que foi enunciada, eu certamente estava apenas perguntando algo a mim mesmo, que por um 'acidente qualquer de percurso', veio a público. Está claro que não perguntei antes a vocês "o que é NBP?". Hoje sim, eu devolvo a pergunta, como pergunta dentro de pergunta, querendo ouvir, querendo saber, querendo arrancar alguma coisa - como efetivamente tem acontecido, está acontecendo e acontecerá no projeto que desenvolvi, estou desenvolvendo e desenvolverei em torno de uma "experiência artística", em que recebo de volta respostas quanto ao uso de um objeto NBP (falo disto mais tarde).

1 Imaterialidade do Corpo, 2 Materialidade do Pensamento, 3 Logos Instantâneo; corpo, mente, instante; invisibilidade, visibilidade, velocidade; pele, pensamento, comunicação; gesto, ação, estratégia; vocês, eu, agora. Estes traços configuram a

\footnotetext{
${ }^{3}$ Apresentado originalmente em palestra realizada no Centro Cultural Oduvaldo Vianna Filho (Castelinho do Flamengo), no Rio de Janeiro, em 29/01/96, a convite de Aimberê Cesar.
} 
primeira resposta. As linhas de um rápido plano de trabalho, pairam como vetores de um projeto.

Uma primeira pausa:

trabalhar com projeto, hoje, indica uma certa opção no rol das escolhas possíveis e impossíveis, pelas quais somos colhidos, antes que possamos escolher. Resolvi colocar-me nessa direção, compondo uma obra que vai se alastrando de uma proposição a outra, como um conjunto de serpentes deslizando pela areia, combinando entre si a construção de um labirinto oiticiqueano - não o "Grande Labirinto", mas aqueles do tipo "newyorkaises", mais 'entertainment'. Configura também - talvez não tão diretamente quanto parece, mas é uma conseqüência inevitável a ser assumida - um posicionamento frente ao circuito de arte nos termos de um outro funcionamento, de circulação mais difícil: nas curvas de um projeto de trabalho em progresso superpõem-se muitas vezes as determinações do artista e do crítico, do escritor e do artista, as exigências da fluência de um pensamento. As malhas desta rede são delicadas, e circunstancialmente posicionadas em direção diversa de uma demanda mais imediata, exigente de uma identidade clara e transparente às necessidades de um certo tipo de mecanismo de circuito e mercado. Será? Vejam bem: nada do que disse ancora-se numa posição pré-concebida, mas em resultados e respostas concretas advindas do processo de circulação e recepção do trabalho que tenho feito. E se coloco isto, aqui, é na importância que cada novo exercício possui na construção deste espaço que me interroga, que se anuncia outro, diverso.

(tento comentar muito rapidamente um aparente caso de delay na recepção da obra, que de resto é tipicamente brasileiro: "e agora, como vocês respondem à minha pergunta, se já deveriam tê-la respondido?" Marcel Duchamp, se aqui nascido, jamais escreveria $O$ Ato Criador, onde discute o papel do público na recepção da obra de arte.)

Estratégia, apenas? Não.

Assinatura, então? Nunca.

Hipnotismo? Talvez.

Reducionismo? Pouco.

Exoterismo? Qual nada. 
Subliminaridade? Um pouco.

Propaganda? Algumas doses.

Narcisismo? Não desconfio...

Intervenção pouco modesta, nos registros visual e verbal da arte, ambicionando a produção de marcas... em você.

Repito:

Intervenção ambicionando conectar os registros visual e verbal da arte, querendo ser produtivo, para que você... fale (eu quis dizer, participe).

Repito:

Estratégia de continuidade no universo das conversas artísticas de modo a prosseguir por meio de novas ações.

Repito:

Estratégia envolvendo trabalhos em registros diversos, num exercício de provação da elasticidade do verbo e do seu... ouvido.

Afirmo (eis, agora, finalmente, a resposta dentro da resposta):

NBP é estratégia que é intervenção que é verbivisual que é mergulho afetivo que é fale-você-mesmo (speak-it-yourself) que é imprinting ou estampagem que é atualização que é envolvimento e incorporação que é compressão sígnica que é enigma generoso que é distanciamento íntimo que é obra em progresso que é...

$$
\begin{aligned}
& \text {...foi } \\
& \ldots \text {..é } \\
& \text {...foi } \\
& \ldots \text {..é } \\
& \text {...foi } \\
& \text {...é } \\
& \text {...foi } \\
& \text {...é }
\end{aligned}
$$

foié. Desculpem-me pela derivação onomatopéica, que soa como foyer, que não está longe de nossa galeria nem de nossa galera. 
A memória da memória, esta jóia delirante: até aqui, hoje, fiz mais do que evocar a memória de fatos produzidos vividos ou testemunhados. Trago fatos novos, ainda que sob imagens com a sensação de já vistas. Existem aquelas que não cansamos de ver, e aquelas que nos provocam enjôos. Entre as primeiras, aquelas que convocamos em momentos especiais, que nos socorrem; entre as últimas, as que evitamos cordialmente e aquelas das quais fugimos - as que nos perseguem! Quero ocupar-me por um instante das últimas entre as últimas, as que vêm atrás de nós e as que nos vêem.

As imagens que nos perseguem, muitas vezes só vêm atrás de nós por que fugimos delas e demonstramos reações corporais, suores, outras respirações - ainda que por movimentos de poucos centímetros, registrados por sensores apenas. Trata-se de caso semelhante aos mais modernos artefatos bélicos, os mísseis termosensíveis. Vejam: talvez, se não for notado nosso pequeno volteio do rosto, os olhos que piscaram um pouco mais acentuadamente ou o espasmo do músculo da coxa esquerda, não ocorrerá a incômoda perseguição. Ou seja, sejamos indiferentes e protegeremo-nos contra visões e divisões - assim dito, parece simples, fácil, indolor. Mas receio ter que admitir que não existe assim escape tão fácil. A imagem que caracterizo deste modo tão ativo, de fato nos vê, arranca em nossa direção, chispa em nosso encontro, derrama-se pegajosa às vezes, outras como um vento suave ou brisa-leve insistente. Estratégias de defesa através da indiferença só alcançam realmente efeito se aquela imagem que nos ataca não existir para nós, se sua existência jaz naqueles outros mundos dos quais o nosso não faz parte - outro regime, outro território. Mas ao mínimo indício de co-habitação, de sincronicidade espaço-temporal... estamos expostos, localizados, vulneráveis. Imagens que agem, acham, caçam, correm, fluem; que vêm e vêem, bizarramente emancipadas.

Muitas nos descobrem pela memória, não de fatos passados - isto seria absurdo! Pois o problema aqui é o da memória como recurso de tempo presente, da experiência aqui e agora, do inesperado e impensado. Talvez aí resida nossa falta de defesa: forjar, num átimo, resistência àquilo que nos surpreende, capturá-lo, desmontá-lo, analisar os pontos fracos e preparar o contra-ataque... haverá tempo, ainda? Indiferença, o único escape? Implantes de memória, foi do que falamos. Mas estes, só se processam através de mecanismos sígnicos de compactação, da redução sucessiva, da concentração de energia. 
"quanto mais poetamenos poesia" (não sei se a grafia está correta), é a fórmula simpática de Augusto de Campos que importamos, não tardiamente, mas como sinal moderno-redundante de um processo precisamente condensado. Anunciamos, sem pompa, a presença da compressão (vejam: não é colocar mais onde cabia menos, através do acúmulo absoluto de dados em um espaço limitado. Esta compressão sígnica de que falamos passa pela produção de mínimos-significantes, com função deflagradora de conteúdos que, no caso aqui, são artísticos - nem sempre é possível produzi-los, pois exige-se adequação da proposta ao processo). Anunciamos, igualmente sem pompa, a presença de uma fabricação de memória, levada a cabo no mesmo processo. Resumindo: é somente no corpo de alguém, como suporte (eu, nós, vocês, eles, elas), que o signo comprimido funciona, ativando algo ou sendo desativado (o que é a mesma coisa).

Admito que creio que, a partir daí, algo acontece.

E isso nunca será pouco.

Deste ponto, exatamente, partem meus mapas: do que acontece ou pode acontecer. Como quando duas pessoas se encontram, eu e você, you and me... ou se desencontram. E também quando se dividem, divergem, embaraçam-se; nodulam e modulam-se. Enrolam, envolvem, amarram-se. Convergem ou escapam: linhas de fuga ou de demarcação, atração e repulsão, contigüidade, vizinhança. Vazios, cheios, laterais, transversais, fluxos e refluxos. O tema do invisível está presente, em termos físicos, à maneira do espaço desta sala compreendido enquanto coleção de ondas de rádio, televisão, radiações de todos os tipos, sejam cósmicas ou eletromagnéticas, ultravioletas ou infravermelhas, atômicas ou subatômicas, raios- $X$, beta ou gama. Acrescentem, a todo este movimento, as linhas ondulantes do corpo orgânico e psicológico: vejam, os mapas tornam-se nem tanto representações cartográficas mas muito mais superfícies de registro das coisas que acontecem à nossa volta, indo e voltando de e para nossos corpos - campo afetivo irradiado.

Quanto a indicar algumas pistas, recorremos a outros mapas, à maneira de roteiros. "Alguém já passou por ali?" "Poderia dar-me tal informação?" Impossível, as referências mudam muito rápido, o que parecia, se foi, mas posso perfeitamente terme enganado. "Vamos, olhe de novo." Sim, insista, mas, aparentemente, tudo que havia para ser visto já o foi. Olhe uma, duas, três, quatro, cinco, seis... $\mathrm{n}$ vezes deixe-se conduzir. Gostaria, apenas que a sensação de poucos caminhos fosse 
substituída pelas muitas opções de cadências e ritmos, numa topografia minimamente divertida, nenhum deserto árido (que é, afinal, uma das opções).

Sob o risco calculado de voltar a um ponto já aqui delineado, o problema que se repete é de que modo desenhar/escrever um diagrama como roteiro de acontecimentos em pleno processo de sua efetivação. Não há um depois suficientemente seguro, como abrigo para elaboração tão sutil, nem há qualquer antes que valha a pena sem nossos roteiros. Então...

Francamente, quem nunca pediu socorro ao outro, quando a situação se afigura incômoda? Ah..., mas nem sempre é assim; tudo, afinal, se inverte. Vejam, como poderíamos ser interpretados se, ao invés disso, pedirmos ajuda ao outro para produzir uma situação não necessariamente cômoda? (nova talvez soe melhor). Pois recorrer ao outro pode ser provocá-lo(a), pressioná-lo(a), para arrancar algo que não sabemos ainda o que pode ser, mas no qual apostamos, investimos. E que será aceito como o que nos fará desviar (ou do que desviaremos). Quero comentar onde estou agora, por quais flancos inclino-me, curvas de derrapagem. "Você gostaria de participar de uma experiência artística? Aceitaria utilizar este objeto em sua casa por um mês?"

O contra-senso de ir ao encontro de alguém que não conheço, sem local ou hora marcados, acharia equivalência, talvez, em narrativas de viajantes, exploradores, navegantes, todos os que embrenham-se por passagens e paisagens desconhecidas. Mas todos possuíam em mente um esboço de seus desejos, do que desejavam encontrar: ouro, riquezas, terras, descobertas científicas - o elo perdido! Mas uma experiência artística não pode funcionar com o desejo prévio de qualquer resultado, pois isto seria colocar-me no lugar de quem experimenta... Imponho-me um limite, até onde posso e devo ir, o que me é permitido fazer, etc. Ou melhor, entender o objeto e a proposta de trabalho enquanto portadores desse eu que recua e recusa, desse bater em retirada estratégico em prol da futura invasão... deles! Naquele container não entro, não posso nem devo, de jeito nenhum - será que é porque já estou lá? Nunca! Perigosa armadilha, que evita que eu também seja produzido, transformado e alterado por esse processo. Vejam: pedir para que outras pessoas façam algo com o objeto é a minha proposta de experimentá-lo! (caímos numa cadeia em regressão infinita). Não seria ainda exato. Esforço-me, aqui, para minimizar a presença de um gesto inicial, inaugural, mas é exatamente no ponto ao lado do objeto - fora dele, como uma nuvem por cima, ou um bater de ondas ao lado 
e em baixo - que indicam-me como local para constituir-me, posicionar-me, ocupar espaço. Garante-se assim a consistência da proposta e um possível trânsito, no tempo presente. Esta experiência sobrevive na tensão entre meu desejo de fuga e desaparecimento e a razoabilidade da existência de um possível artista.

Obrigado. 


\section{Forum Internacional de Revistas de Arte Contemporânea} sinopse de apresentação

Tema III: A crítica como literatura, como filosofia, como interpretação, como fábula e como prosa

título: "A crítica de arte como um terreno privilegiado da ficção contemporânea"

Como entender esta afirmação e articulá-la nos termos estratégicos da produção de uma revista de arte? Que tipo de exercício ficcional é interessante hoje como programa de ação? Trata-se de compreender as possibilidades das ferramentas de produção do discurso crítico, articulando-o com as condições do campo da arte (e da cultura) contemporânea: produzir sempre um encontro estranho, tenso, sinuoso, divertido, entre textos e trabalhos de arte de modo a confundir e sobrepor suas fronteiras e limites. Hoje impõe-se um uso da palavra não mais sob o modo reativo (em que os discursos são produzidos após os acontecimentos, servindo apenas para legitimá-los ou criticá-los, sob a forma do comentário) mas principalmente prospectivo, configurando mais do que nunca uma forma de ação, produção de espaço e criação de um território. Neste jogo de espacialidades crítica e trabalhos de arte estabelecem um fértil protocolo de confrontações: enquanto que os trabalhos de arte estabelecem as estratégias concretas de ocupação, lançando-se aqui e ali sob a forma de objetos, imagens, instalações, performances, etc, o discurso crítico tece suas linhas através de todas essas obras, propondo jogos narrativos ou antinarrativos de reordenação e condução do pensamento. Mas não basta ocupar com invenções e experimentações visuais e discursivas este imenso campo de vertigem verbal-visual: a atualidade nos convida a agenciar esta produção com as demandas da vida e da cultura, colocando em jogo a fabricação transitória de identidades, a intervenção em contextos locais, o estabelecimento de virtualidades e coordenadas de ação, o desenvolvimento de circuitos, membranas e regiões de contato. É aí que entra em cena a revista, como suporte estratégico de um projeto que se quer 
necessariamente coletivo em sua demanda. Escrevo a partir de um determinado circuito, o contexto da arte brasileira, com suas idiossincrasias e particularidades, limites e potencialidades. Dentro desta locaização geográfica e cultural chamada Brasil é necessário um esforço imaginativo e ficcional para produzir um jogo de consistência discursiva como parte de um projeto efetivo de intervenção - que se torna visível a partir das obras produzidas pelos artistas contemporâneos - $\mathrm{e}$ entrelaçamento com o panorama da atual globalização e transculturalidade. 


\section{NBP $x$ eu-você}

(2000)

\section{O 'x' do problema}

Este 'x' está no lugar da palavra 'versus'. É de confronto, portanto, a situação configurada: esperemos ansiosos, então, pelo resultado. Posicionem suas cadeiras, escolham os melhores lugares do estádio. Mas uma vez começada a partida as cadeiras de pista, arquibancadas, cadeiras especiais, numeradas e camarotes irão transportar-se automaticamente para dentro do gramado. É aí que se passa o jogo: no lugar de onde se assiste, com quem se assiste, e não o contrário.

Confronto. A única continuidade que se efetiva - aos saltos. Oportunidade única para trazer à superfície conjuntos de relações especiais, importantíssimas, atraentes, envolventes e sedutoras (boatos urgentes: todos seremos capturados) "há os que as colocam em dúvida, relações, mas vocês nos arrancam, puxam, movimentam, exteriorizam, evidenciam, ora pois!" Atenção: nunca os que se confrontam são eliminados: estarão lá, durante e depois, para conferir os resultados, interagindo novamente, com todas as suas diferenças irredutíveis, inevitavelmente, transmutados em outra classe.

Quando a história da arte é escrita em tempo real - como agora - todo cuidado é pouco. Uma parte desta história alimenta o mercado e assim pode sustentar-se frente às agruras do dia-a-dia (os tempos de hoje não estão fáceis...). Outra parte diverte e faz a alegria da mídia, fornecendo pistas para as notícias ou para as entrelinhas dos noticiários e cadernos culturais. E ainda uma terceira parte (enfim) aventura-se em caminhos não privilegiados pela percepção ou pelas tramas habituais da visibilidade, arriscando-se a um traçado que não imprime palavras mas que explora possibilidades (quando possibilidades despertam atenção?). Há uma quarta parte que aparentemente receia o impacto frontal, o confronto que implicará 
no desenvolvimento de outros mecanismos críticos, novos saberes mesmo, interessantes; esta parece semi-adormecida, em sonâmbula atuação.

A situação exige um cálculo, sim, pois a tendência geral das últimas décadas é mesmo a da aceleração sempre mais avançada dos processos. Teremos portanto alguma chance ainda de usarmos os terminais e constituirmos algum tipo de banco de dados que nos disponibilize pelo planeta. Não como uma estratégia de fuga, mas de disseminação, espalhamento, contaminação - se ainda quisermos insistir na metáfora biológica, agora coisa concreta e úmida. Assim, por favor, nada da ilusão de que "entrar para a história" (expressão de anacrônico som) resolverá, quase anedoticamente, uma parte de nossos problemas (refiro-me àqueles básicos, de sobrevivência, sob outra temporalidade, aquela da existência).

Talvez o artista devesse se calar frente ao que faz: "que venha o público" (sim, o silêncio é uma grande forma de hospedagem). Mas, se falo e ainda assim alguns vêm até aqui, o que devo pensar? Que minhas palavras funcionam como alguma espécie de filtro, algum tipo de membrana seletiva?

O principal confronto do artista será sempre consigo mesmo? Sim, livrando-se de seus 'eus' interiores (personagens remanescentes de uma fiç̧ão ingênua), deslocados na medida do possível para a retaguarda do combate. $\mathrm{O}$ grande confronto que esta posição, este local estrutural (e móvel) do artista almeja localizase além de um 'pós-eu', caoticamente fragmentado, dissolvido nos olhos dos outros. Indivíduo inventando lugares que criam em torno do outro tal ilusão de linguagem é aí que pode ocorrer alguma tempestade, tormenta, turbulência, conflito ou disputa. "Criar problemas para si próprio", é o nome carinhoso desta insensatez.

\section{NBP $x$ eu-você}

Parâmetros do projeto NBP são desdobrados sobre inflexões EU-VOCÊ que constituem pontos de curvatura deste plano. 
NBP entrará em você pelo lado de fora, encostando em sua pele, mobilizando-o de leve. Este é afinal o processo, ou seja, envolvimento físico - sem demasiado exercício ou transpirações - enquanto processo mental: mexer-se sempre, colocarse de lado, seguir em frente olhando à direita, esquerda, em cima e em baixo.

NBP funciona atraindo o espectador para um encontro perceptivo que envolve subliminaridade, persuasão e repetição, como técnicas de uma transformação instantânea, um implante de memória. Sentir seu corpo obsoleto, obrigá-lo a alongar-se por dentro de um lugar não especialmente confortável - mas nem por isso menos acolhedor -, refazê-lo, reconstruí-lo: processar a sensorialidade (processar-a-sensorialidade), ao mesmo tempo e depois; continuamente.

EU-VOCÊ funciona como tecnologia de visualização das linhas de inflexão, sob o impacto destes dois importantes lugares: aquele de quem fala; aquele do outro. Eu falo, você ouve. Eu ouço, você fala. Ambos falam ao mesmo tempo: você quer ser eu lançando-me a você; não mais quero ser eu, contento-me em agir como você.

A partícula EU-VOCÊ é a instauração do conflito, dinâmica não determinista das relações onde o resultado é imprevisível. Índice de um jogo de flexibilidades, convite a viver a vida sob o impacto sintético de elásticos: o espaço aqui é simples campo de atrações, repulsões, sobreposições, sob o risco da dissolução quando de sua captura no espaço ativo do outro. Implanta-se um lugar de jogos, imantação dos olhos através do corpo, do corpo através dos olhos, sendo o pensamento parte do mesmo impulso de sabor forte que tudo percorre - aos poucos.

\section{De Como Retirar os Traços de Infinito Secularmente Acumulados no Delírio}

Como obter o delírio?

Estado de coisas fundamental como proposição de colocação de coisas. 
Pois vocês sabem, as coisas colocadas formam algo, uma configuração, no mínimo, ao menos uma demarcação, apenas um local. Pode-se tramar algo como um antilocal ou um buraco negro em sua concepção antiga, quando ainda trabalhava-se com a noção de infinito. Quero um delírio afastado do infinito, próximo do desejo, distante do incomensurável, isso porque quero por minhas mãos sobre ele. Acariciálo(la). Vendê-lo. Como tocar com os dedos ou com botões, teclados, chaves conectoras, aquela região cerebral responsável pelo comportamento responsável, alterando a neurologia do infinito sináptico?

Repito que as coisas encontram-se multidimensionadas, virtualidades empacotadas, pré-embalsamadas, pré-natalizadas - tudo como pretexto de latência, nada como muralhas, ao menos se os materiais forem elásticos, extensíveis.

Como pensar fronteira e rompimento simultâneos? Adoraria obter o delírio, mas não o infinito clássico, nem a orgia ritualizada, apenas um plano perceptivo amplo, simplificado, como pacote turístico - sem preocupar-me com idas e voltas, cartões de crédito e cheques bancários. Delírio eficiente, impulsionador temporal compacto. Agora os números transpareceriam em suas modalidades lingüísticas, em seus aspectos simbólicos, em sua natureza como elementos estruturadores de um sistema complexo - mas que guardam a capacidade de deslocamentos no tempo e no espaço.

Algo que não me obrigue a agir, mas que aconteça. Algo como organismos dos quais se alcance seus pontos-chave. Artifício eficiente desencolerizado. Delírio desempregado.

Um acontecimento viável sob a geografia localizada, nos terrenos da urbe-fantasma, aqui no circuito eletrificado, o nó - exercício de deslocamento do imaginário ao sol.

Esta tiragem se completará nunca, é ao mesmo tempo menor e maior que o infinito, esse número mental localizado, radiografado, com obtenção de um copo de água 
pesada. As infiltrações de substância branca e substância cinzenta influem no peso dos sistemas. $\mathrm{O}$ alvo absorve fisiologicamente a visão. Esqueçam a contagem regressiva vídeo-popularizada, pois já içamos o infinito de maneira prática e sem a utilização de guindastes pesados: ele está em órbita, naquela cápsula de chumbo.

Boa sorte.

Esta advertência é matemática. 
superpronome

(2000)

convergência de pronomes pessoais

em uma única palavra.

euvocê

vocêeu

mistura, hibridização, contaminação recíproca

de um pelo outro, de eu por você, de você por eu,

numa só coisa. êxtase do objeto,

síntese ideal do desejo.

instrumento de negociação para ações

de uma alteridade incorporada, em fuga. 


\section{passagens (NBP)}

(2001)

Imagens de um cinema expressionista sem sombras, determinadas em um preto e branco de enquadramentos distorcidos, na repetição incessante do percurso das câmeras - as mesmas, sempre. Sempre apontando para as passagens, para a moldura das portas, a silhueta que passa. Parecem novas a cada ciclo - que insiste em se repetir fazendo-se diferente. (Por quê?) Uma estranha expectativa reaparece sempre e sempre: de momento em momento limpam-se os olhos, sem deixar traços. (EU) olho para um lado, olho para o outro. Fecho os olhos, apuro os ouvidos, baixo a cabeça, dobro os joelhos, relaxo os braços, solto os ombros, repuxo a coxa, afrouxo o estômago. É tão rápido o começo da nova sessão - podemos colocar sob suspeita se de fato tanta coisa aconteceu. Imagens sem sombras que obedecem a si mesmas e não correm atrás de quem passa: procuram lugares que vivem em si próprios e vibram de alegria por reconhecerem, celebrarem e comunicarem sua própria importância. Inútil espectro de aceleração imprevista.

\section{"...todas as tardes..."}

Sim. Aceitar as condições não implica necessariamente "estar em condições de". O que se repete é o hábito, o costume de ficar feliz devido às mesmas eternas ações. Querer dar um basta nisso é desejo latente, o risco é o caos e o impulso pode ser a alegria que pode explodir de tal encapsulamento. Projeções como esta podem configurar-se de modo muito idealizado, talvez demasiadamente, não sei. Não posso esquecer de sua expressão quando abriu a porta e me viu de repente, ou quando em meio à multidão caí e fiquei para trás enquanto você seguia em ritmo constante, imperturbável. Imperturbável. Imperturbável. Imperturbável.

\section{"...entrementes..."}

Muito azar. Azulejos que refletem sombras de corpos errantes. Almofadas oferecendo aconchego a quem se cansa dos passeios rebeldes. Ondas de um mar revolto que se altera a cada olhar. Sons repetidos. O que se conta é que as conversas estenderam-se até muito tarde. Seu corpo pode deslizar ao lado da parede e as mensagens que enviar serão bem recebidas, decifradas e redirecionadas para mim. Elas nunca perdem de vista as rampas, elas adoram descer lentamente, elas balançaram todo o chão, elas desapareceram de uma só vez. Treinamentos em excesso. $O$ atraso foi de apenas alguns segundos mas a coincidência maior não foi comprometida. Derrubar as 
coisas não tem sentido final, a menos que se precipitem por todas as saídas os conjuntos e grupos transformados, transtornados. Sabe, muito se diz a respeito do espaço de intimidade de cada pessoa; caberia agora produzir um afastamento das colônias de habitantes que ali se instalaram ao longo dos anos. Nem calor, nem frio.

\section{"...se considerarmos que..."}

Se você não se importar eu não ligo. Não insistirei. Você saiu na frente, avançou primeiro, atravessou. Percebi quando seus olhos reviram-se percorrendo todo o espaço. Olhando para baixo, para os cantos, enquanto saltava. Saltando, enquanto andava e sentia na pele impactos diversos. Pensava e buscava equilíbrio com os braços no metal frio. Um giro completo do corpo e o percurso percorrido em curvas. Requebrando em meio ao êxtase sensorial, logo abandonado antes do clímax. Mudanças súbitas de sentido, plantão 24 horas.

\section{"...conforme previamente acertado..."}

Confortavelmente desci a rampa, olhos relaxados, sem contar com qualquer imprevisto. Os ruídos estavam numa taxa entre o controlável e o suportável, mas eu acreditava que se deslocariam agora para a região do "muito agradável". Controlar o espaço em torno pela dinâmica dos sons requer mais do que um envolvimento automático nas coisas do dia a dia; implica em atenção com a pele. As camadas entre meu rosto e todas as fontes sonoras do mundo neste instante imediato são algo que felizmente escapa à determinação, adquirindo autonomia além dos recursos perceptivos de que dispomos. Também as temperaturas do corpo funcionam como ondas, fenômenos parecidos com as marés e correntes, onde a pele, a sub-pele, as camadas que se sobrepõem acima e abaixo (ao lado dos ossos?) são sentidas como um ambiente próprio com caprichos e impulsos particulares, ainda que inter-relacionados. Vibrações maiores sob os pés quando se está muito cansado. Em meio à multidão na praça, ao cair da tarde, depois de horas ao sol, sem querer desviei-me da mensagem que prometia surpresa. A cada mudança de imagem senti que era aquele mesmo o instante de insinuar-me, antes que um cataclisma qualquer - destes diários - desviasse completamente a atenção daqueles que gostaria de conservar em meu raio de ação. 
"módulo de transatravessamento do artista-etc."1

(2002)

transatravessamento

autocontenção

o trabalho não está dentro de sala nenhuma, é ele mesmo a sala que o contém

oferecer espaços, jogos, água, almofadas

convite ao esforço de atravessar portas: performance obrigatória

ser visível ao longe, sem privacidade qualquer, ao mesmo tempo ver

ir com os olhos sem corpo até onde o corpo não pode ir e configurar assim os espaços

sistema em tempo real:

atravessar, jogar, olhar, perceber as ações no mapa, descobrir relações no mapa

- onde estou, onde estamos?

grande escultura, deambular em torno, mirar ao longe

transatravessamento \& obstáculos

repetição da marca, trauma, obsessão: livrar-se dela e sair de si

envolvimento do pequeno outro e do grande outro coletivo

fantasmática do mundo interior transformada em anedota bioquímica de domingo

transatravessamento \& aceleração

fruição física, beleza rompendo a pele através do cansaço e do acolhimento

jogar: alegria pés encoste a cabeça imagens que passam e pensam

contágio rápido todo o pouco tempo do mundo - repetições

mirar o alvo apressado sorrisos de sucesso sem premiação, ainda assim satisfeito

sorriso ao círculo em torno de seu pescoço atravesse as passagens músculos em forma

através da forma desformatá-los em ângulos desfavoráveis portadores de promessa

euvocê aqui agora aqui vocêeu - leve deslocamento

processo metálico gigantismo quase que solto junto às coisas desviando ventos

transatravessamento \& outros

- eu quero ver: geléia adversa

V.C.P.: vivência crítica participante - sem saída, meu bem

entrar e sair permanecendo ali dentro atento aos sons

sim, transatravessamento de segunda a domingo

ver sem olhos ou com olhos nos pés

paisagem cinema registro de pistas e sombras rumo a novos lances

deflagrar a fala na sala discursos considerados voz como importância fundamental

\& passagens: ultra movimentos sensíveis transbordantes de

${ }^{1}$ Sobre a categoria "artista-etc." cf. meu texto "Mistura + Confronto" no catálogo da exposição homônima, Central Eléctrica do Freixo, Porto, Portugal, 2001. 


\section{Sistema-Cinema}

(2002)

\section{transatravessamento}

aceleração positiva ou negativa: sua velocidade jamais será a mesma depois deste contato. Não se esqueça: "o pensamento é mais rápido que a velocidade da luz" (já foi dito). Sensorialidade como deslizamento entre o caótico e o prazeroso, tocando a superfície das coisas (ir e vir, ir e vir, ir e vir são parte do processo - ritmos oceânicos). Afetos criam ligações de seda com a força de cabos de aço: conexões, redes, teias e outras coisas trançadas imersas em tal vocabulário.

\section{adversa geléia}

olhares para o entorno, despindo-se de alguns automatismos, aceitando a fluência de outros. Mergulhando no que imensamente nos escapa e resiste e é ao mesmo tempo estranhamente familiar: passando ao lado nos captura e transmite ao longe sempre. Estado momentâneo quase chegando a ser junto comigo.

\section{artista-etc}

a imagem do que se faz misturando-se ao que não se faz; (des)construindo enquanto se aponta em mil direções e se apronta em prestações. Frágil resistência, sutil insistência: nunca apenas um lugar nem a mesma rotina de procedimentos; sempre as simultaneidades e o olhar magnético, a confiança no lugar. Compactação impossível do poético singular que escapa sempre, tudo arrastando em volta. Voraz. Contenção. Saltos.

(C) Sistema-Cinema V.C.P. 2002 


\section{agentedupla://}

(2002)

iniciativa que se propõe a:

(1) constituir interfaces membranosas de agenciamento para microeventos (membranas são permeáveis);

(2) costurar redes e tramas cúmplices e limítrofes de aceleração e desaceleração do pensamento;

(3) instaurar um campo crítico que não rejeite os nós afetivos (manifesto-adesivo nós nós);

(4) investigar a presença, permanência e pertinência dos suportes tecno pero no mucho - correr atrás dos dispositivos mecânico-eletro-eletrônicos-digitais enquanto valiosa ferramenta de ação;

(5) agir e articular projetos definidos a partir de uma profusão de siglas, que encontram terreno conjunto de movimentação e revelam uma face de trabalho voltada para o corporativo e/ou comunicativo:

$$
\begin{aligned}
& \text { ILA - Instituto de Legitimação do Artista e/ou do Amor } \\
& \text { PUPA - Produtos de Uso Pessoal do Artista } \\
& \text { NBP - Novas Bases para a Personalidade } \\
& \text { VCP - Vivência Crítica Participante } \\
& \text { etc }
\end{aligned}
$$

(6) a prática é a da afirmação, onde não se abre mão da ação-arte enquanto instauradora de territorialidade própria; 
(7) a pragmática se dará (vertente B) através de intervenções pontuais do tipo escavações pseudo-arqueológicas, confrontos construídos, compilações de microhistória, anti-história, trans-história (prefixos multiplicados ao infinito)...

(8) parcerias de trabalho (vertente A): entrelaçamento de nossas poéticas com (in)consciente permissividade: acreditamos em misturas vitaminadas;

[daniela mattos \& ricardo basbaum] 


\section{Circuito de arte em deslocamento}

(2003)

1.

O título desta palestra guarda já uma redundância, na medida em que a própria idéia de 'circuito' já traz em si a idéia de 'deslocamento': há entrada [input] e saída [output], entre as quais se dão processamentos diversos dentro da caixa preta. Falase também em 'sistema'. Não que se queira aqui discutir o deslocamento disto ou daquilo, mas perceber deslocamento como movimento ou estado de coisas com o qual se trabalha.

\section{2.}

Logo, trata-se de pensar o circuito da arte, ou seja, quais os trânsitos que se estabelecem através de seus vários 'nós', entre as diversas componentes do sistema. Fala-se sobretudo em termos de se traçar uma economia do sentido ou do significado da obra e seu jogo de relações, de modo a dinamizá-lo. A obra de arte em um circuito, ou um circuito de arte, surgem como noções para este meio a partir do momento em que a modernidade executa uma dobra sobre si mesma, uma inflexão - em que o moderno deixa de ser apenas crítica da tradição e começa dobrar-se sobre si: torna-se contemporâneo, pós-moderno.

\section{3.}

Vê-se isso claramente nos anos 50, por exemplo, quando diversos rituais do próprio jogo da arte são encenados pela arte: ver os trabalhos e ações de Yves Klein, Piero Manzoni, Robert Rauschenberg e Jasper Johns. Nestes gestos há um esforço para se começar a articular um outro modo de pensar - por sistemas, por circuitos. Não mais um pensamento linear, evolutivo, em que se supera o anterior tendo como fim a redenção do espaço histórico idealizado. Este novo pensamento sistêmico - em circuito - se faz agora por redes, vizinhança, afinidades, afetos (olhar para si mesmo através do outro sem aniquilá-lo, deixar-se tocar, constituir um campo de relações, um teatro de eventos), desvios. Quando se tem o movimento do circuito como estado de coisas não há pureza, linearidade, projeto ou fim. 
4.

No campo das artes visuais constuma-se dizer que a noção de circuito ou sistema de arte consolidou-se de modo muito claro nos anos 60, com a chamada arte conceitual, que tomou para si a tarefa de investigar a produção de sentido específica do campo através de um tríplice conjunto de manobras: (1) em que o circuito se torna visível, evidenciado, lançado a um primeiro plano figurativo e operacional; (2) em que as obras são desmontadas em conjuntos de relações, como a muitíssimo utilizada 'relação entre texto e imagem', mas também outras séries envolvendo som, espaço, espectador, etc: temos aí as instalações como meio em que se colocam diversos destes termos em relação; (3) em que a arte é separada da estética para que se discuta não apenas a verdade através do sensível, mas sobretudo se investigue a natureza da obra de arte, as propriedades de um campo artístico, que não mais se reduz apenas a um elemento do jogo formal mas vai ser definido nas relações com seu próprio circuito, e se abrir para um jogo interdisciplinar abordado através de diversas áreas do conhecimento. As poéticas são articuladas como campo de problemas, numa via de ação que se estende da interdisciplinaridade à hipermídia. Não mais se irá falar de gêneros artísticos (pintura, escultura, desenho) mas de meios - sobretudo híbridos - à disposição do artista Exemplos: tanto o objeto específico minimalista (Donald Judd) quanto o não-objeto neconcreto (Ferreira Gullar) são propostos como híbridos pintura-escultura). Aí se situa o nascimento das novas categorias da performance, do objeto e da instalação, assim como as diversas combinações das experiências multimídia.

5.

Percebe-se desse modo como circuito / sistema passa a ser um modo de pensar, introjetado na própria concepção do que se quer obra ou estrutura pensável, problematizável. Não se trata de deslocar qualquer objeto, mas de conceber as coisas de outro modo, enquanto entidades processuais que se lançam de imediato à vertigem de jogos de relações, ao seu destino de circulação. Estabelecer, trazer à tona os dispositivos de trânsito e circulação não é simples exibição de coisas em seus caminhos ou trilhos, mas sim perceber sentidos em percursos amplos, valorar 
desvios, determinar importância ao processo de deslocamento como uma entidade de grupo, elemento coletivo.

6.

Organizar as questões em circuito, ordenar as informações em caminhos, sistematizá-las: processo muito importante, pois revela que este gesto (de construir um circuito) é modo e maneira de pensamento, que implica na construção de interface em que se captura o outro e se propõe caminhos e estruturas de produção de valor a partir dos percursos estabelecidos: ênfase na processualidade, proximidade, vizinhança: traçar uma rede, agrupar os pontos a partir do gesto de capturá-los, ordená-los. Daí que o simples gesto de construir o diagrama de um circuito seja ativar um grupo de objetos-relações-ações e produzir fios de pensamento em rede: um circuito é oposto do caldo homogêneo de objetos similares e sem valor: propõe sempre diferenças dinamizadas a partir da singularidade dos nós pelos quais atravessa. Desenhar é propor relações, construir rede, rizoma, conectar o próximo e o distante. A beleza de se desenhar ou propor um circuito é poder arbitrar os centros de atração, aqueles nós a partir dos quais a rede se distribui, avança ou recua. Nesta dinâmica, passagens e conexões são estruturas de produção de valor.

\section{7.}

Daí a importância de projetos como 'brócolis vhs'e 'cinema marginal', onde a simples construção do site reveste-se de significado por ser exatamente interface a partir do qual o pensamento se ordena enquanto produção de um circuito que produz valor para o próprio trabalho - constrói valor -, lançando-se ao mesmo tempo para dentro de si mesmo e para o exterior. Através do website as coisas não são acessadas diretamente, mas através do circuito / interface em que todos os elementos presentes se reforcem mutuamente, produzindo o efeito de geração de sentido. Uma das mais importantes consequências são as possibilidades que se abrem de acoplamento com outras estruturas homólogas. Exemplo: The Atas Group e seu projeto de articulação de vários meios e suportes, que deslizam uns sobre os outros. 
8.

A própria 'arte do vídeo' já nasce nessa condição de passagem entre linguagens e daí sua inteligência ter sempre sido esta: hibridações, combinações de procedimentos de diversos campos. Ou seja: o específico do vídeo se materializa sempre em encontros, seja da imagem eletrônica com o cinema, da imagem com o objeto-instalação, da imagem com a música, etc. Qual sentido haveria em se buscar o 'puro específico do vídeo'? A singularidade deste meio se localiza mais nos encontros do que em sua auto-definição. Isto está claramente colocado por Nan June Paik já em sua Exposition of Experimental Television, na Galerie Parnass, Wuppertal (1963), onde os trabalhos propostos organizam-se como objetos em que os recursos do aparelho de TV se voltam para si próprios, mas ao mesmo tempo dialogam com o lugar da comunicação e da construção de redes telemáticas. Não há mais como olhar o meio sem considerar sua ampla rede de conexões.

9.

A combinação principal para esta compreensão é a associação entre 'cibernética' e 'arte conceitual': noção de circuito + ferramentas para discutir o próprio circuito. Não há como negar a influência de tal combinação nos mais diversos campos do conhecimento, quando se percebe claramente a dificuldade metodológica de se isolar um objeto de contornos estáveis - cada visada é fruto de negociações de fronteiras e limites, assim como é proposição de campo conectivo, rede, território. Pode-se também acrescentar a topologia, como ferramenta renovadora de visualização dos objetos construídos dentro destas possibilidades das coisas em deslocamento.

10.

Deslocar o circuito só pode ser pensá-lo, utilizá-lo, reconfigurá-lo para mais uma intervenção - redesenhá-lo. Há aí uma imperatividade do presente: funcionamento e permanente atualização. Um circuito não tem futuro, só o presente de seus usos e deslocamentos aqui e agora. Entretanto uma dimensão virtual se faz presente na medida em que mobiliza possibilidades de seu programa. Enquanto for capaz de viabilizar encontros e conexões um circuito permanece existindo; sem isso, 
cristaliza-se, hibernando até sua próxima possibilidade conectiva. Sejam dinâmicas de grupo, coletivos, revistas, laboratórios, a eficiência das mutações propostas por todas estas possibilidades de intervenção se dá na medida da habilidade de se perceber conexões entre as coisas, mantendo sua capacidade vibratória de produzir desvios e redesenhar - ainda que momentaneamente - seu mapa de ligações ou de modo mais perene - impor um novo traçado para os processos, fazê-los literalmente passar por aqui.

11.

Assim, circuito é também o informe, o redesenho, o ultrapassamento de limites olhando para fora de si no exercício de uma voracidade conectiva. Talvez aqui, nesse voltar-se para o exterior, se encontrem pistas estéticas: o êxtase sensorial se dá sempre como o próximo link ou conexão - ao mesmo tempo consumo e transgressão, pois as ligações em um circuito se dão sobretudo entre heterogêneos (relações, afinal): a diferença é a partícula que acopla. Seja 'oficial' ou 'aternativo', tudo são circuitos - diferindo entretanto em termos de amplitude, maleabilidade, alcance e fluência das conexões, potencial de auto-remissão que busca valor em si, na qualidade das conexões (isto é, ligações fortes, fracas, estáveis ou instáveis, conforme o caso). Abre-se o caminho para uma compreensão política das dinâmicas afetivas, quando se tem a amizade como forma política de construção da proximidade na distância, enfatizando as membranas e regiões de contato e agrupamento entre sujeitos singulares e acreditando no potencial transformador de tais processos (nada de amizade fraterna cristã, pacto de sangue ou intimidade compulsória com o poder: o que se quer aqui é o trânsito afetivo como política de alianças entre aqueles que vibram na dimensão de um combate que é aquele da dinâmica produtiva das ações coletivas. Ver Francisco Ortega, Para uma política da amizade: Arendt, Derrida, Foucault, Rio de Janeiro, Relume-Dumará, 2002).

12.

Diante das poéticas do processo, sob a dinâmica do trabalho em progresso, não há como concluir, mas sim colaborar na continuidade (imprevista e acidentada) destes percursos. 


\section{Diferenças entre nós e eles ${ }^{4}$}

(2003)

Permita-me começar este breve artigo com uma ligeira contradição: convidado para escrever sobre nós e eles, colocarei a minha ênfase em um outro pronome, o mais do que comum "pronome pessoal da primeira pessoa do singular", eu. Nas próximas páginas, minha intenção é conduzir o discurso em torno desse pronome óbvio e superutilizado, movendo-o através de caminhos tortuosos e diferenciados que nos conduzirão a muitos fins, antes de finalmente alcançar as áreas dominadas por nós e eles. Assim, você está convidado a seguir um processo no qual poderá testemunhar os procedimentos de transformação de eu em nós e eu em eles. Se você considera essas passagens ou processos particulares de constituição de nós uma simples questão de adição de vários eus (eu + eu + eu + eu + eu + eu...), ou a formação de eles através da reunião de vários eles e elas (ele + ela + ele + ela + ele + ela ...), não teríamos um problema interessante com o qual lidar. É muito mais desafiador procurarmos outras formas de relação entre os vários pronomes pessoais - tentemos achar outros modos de chegar a nós e eles escapando da fórmula fácil da simples adição do mesmo. Outros modos de operação e transformação das palavras serão oferecidos aqui. As principais referências serão extraídas de algumas imagens que compõem certos trabalhos de arte (ou dispositivos similares) que produzi, organizei ou coordenei nos últimos anos.

\section{1. jogos e exercícios eu \& você}

O primeiro processo que gostaria de discutir envolve um projeto em que convido grupos para vestirem camisas estampadas com os pronomes 'eu' e 'você'. A proposta é de sempre realizar e participar de jogos e exercícios desenvolvidos coletivamente (embora às vezes instruções prévias possam ser utilizadas). É um

\footnotetext{
4 "Differences between us and them" foi publicado em Static Pamphlet [http://www.staticops.org/archive_october/essay_12.htm] em outubro de 2003, como parte de uma série de artigos que tinham como ponto de partida questões em torno de "us and them". Originalmente escrito em inglês, foi traduzido para o português por Jorge Menna Barreto. (N. do A.)
} 
trabalho sobre dinâmica de grupo ao qual sempre me refiro como 'person' ou 'group specific $^{5}$. Todas as vezes os resultados diferem, de acordo com as pessoas que participam e os grupos que são constituídos durante o tempo em que praticamos juntos (que pode variar entre um dia e duas semanas). Os resultados são organizados em duas direções diferentes: uma, é o registro estabelecido em relação à memória do corpo, acessível somente aos que compartilharam da intensidade da experiência, sendo refratária à documentação; a outra, seu oposto, é constituída através de imagens e vídeos produzidos durante as ações. Essas imagens são concebidas e administradas sem o compromisso de representar a realidade da ação e, portanto, abrem espaço para a ficção e a narrativa através da edição em vídeo e reenquadramento fotográfico - ou seja, a intenção é afastar-se da 'pura' documentação e estar livre para jogar com as imagens de acordo com propósitos expositivos, que incluam os principais conceitos do projeto. Portanto, cada proposição de jogos e exercícios eu-você acaba resultando em duas experiências: uma para os participantes e outra para a audiência. Ambas pretendem ser intensivas. A fotografia abaixo, mostrando um momento desse projeto, nos leva à primeira parada:

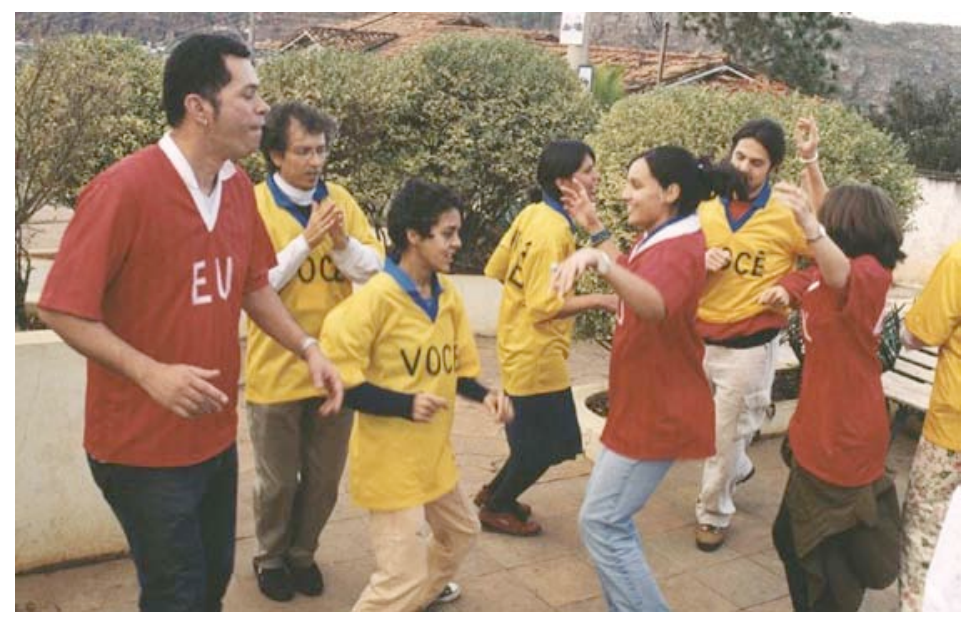

eu-você, serigrafia, camisas, jogos, exercícios. Realizado em Diamantina, Brasil, 2000.

\footnotetext{
${ }^{5}$ Ou seja, que leva em conta e é definido a partir da especificidade de cada grupo ou pessoa. Esses termos foram mantidos em inglês para que continuem fazendo relação com o termo site-specific, expressão da língua inglesa comumente utilizada na discussão sobre arte e que não costuma ser traduzida para o português. Sobre esse assunto, ver [www.corpos.org/anpap/2004/textos/chtca/jorge_e_raquel.pdf] (N. do T.)
} 
Quando proponho uma performação ${ }^{6}$ de tal conjunto de jogos e exercícios, sempre insisto em fazer parte do grupo, vestindo uma camisa 'eu' ou 'você': não vejo sentido algum em ficar de fora, atuando como uma espécie de 'diretor' ou coordenador de atividades, separado do grupo. O trabalho não opera como um conjunto de ações e movimentos pré-estabelecidos: qualquer instrução ou decisão deve vir a partir (do interior) do coletivo. Se eu quiser contribuir, devo ser um integrante, como os outros. O que vemos na imagem acima é um conjunto de pronomes eu e você que poderia ser descrito como:

$$
e u+v o c e ̂+e u+v o c e ̂+e u+v o c e ̂+e u+v o c e ̂+e u+v o c e ̂
$$

Claramente, sendo eu mesmo um dos 'pronomes em ação', só posso me referir ao grupo como nós - qualquer um do grupo, suponho, falará da mesma forma:

"estamos jogando juntos, vamos pensar o que nós vamos fazer para o próximo exercício". A fórmula que representaria a transformação de eu e você em nós, seria algo como:

$$
n(e u+v o c e ̂)=\text { nós }
$$

No entanto, difiro do grupo pelo fato de operar como aquele que traz a proposição para os outros. Todas as vezes que os jogos \& exercícios eu-você re-acontecem (e eles nunca são os mesmos, devido não somente às especificidades da pessoa ou grupo, mas também à relação direta com o lugar), tenho que desempenhar o papel de facilitador, ajudando a criar as ligações necessárias a partir das quais o grupo - e não apenas um monte de pessoas - irá emergir como entidade. Mesmo que eu vista as camisas como os outros participantes, minha condição não pode ser nivelada (note-se que não estou me referindo a nenhum tipo de hierarquia, mas enfatizando um papel diferente) em um padrão homogêneo que me igualasse aos outros

\footnotetext{
${ }^{6}$ O termo performação foi apropriado da noção de "espaço de performação" discutido por Regina Melim em sua tese de Doutorado. Trata-se de uma idéia vinculada à experimentação e à participação, como tentativa de alargamento e deslocamento do conceito de Performance Art. Referese à performance do participador que surge do encontro entre obra e espectador como possibilidade de criação de um espaço comunicacional ou relacional. Ver Regina MELIM, InCORPOrAÇÕES: agenciamentos do corpo no espaço relacional. Tese de Doutorado, PUC, São Paulo, 2003. (N. do T.)
} 
integrantes do grupo. É mais importante enfatizar as diferenças e os papéis de cada um do que pressupor erroneamente que a estrutura do grupo transforme todos os integrantes em um só, indiferenciado. Assim, se tiro minha camisa durante as performações, perco o direito de dizer nós; a partir desse momento (para mim), o grupo passa para a condição de eles:

$$
e u-n(e u+v o c e ̂)=e l e s
$$

Essa mudança de nós pra eles aproxima-se do deslocamento a que qualquer um de nós é submetido quando confrontado com a passagem de dentro para fora de um grupo ou coletivo. Como qualquer outro, o 'processo de passagem' possui sua própria dinâmica, trazendo algumas circunstâncias espaço-temporais que apontam para as particularidades de certos entrecruzamentos. $O$ traço mais evidente é que o espaço que hospeda o grupo é majoritariamente paradoxal, no sentido em que ele de fato depende de ligações e linhas invisíveis - pertencentes ao afeto e forças similares - que precisam ser permanentemente re-negociadas por seus membros. Estar dentro ou fora pode ser a mesma coisa; na verdade, estamos sempre desempenhando ambos os papéis, administrando a superposição de diversas estruturas inclusivas e lutando para não sermos devorados ou sufocados, presos dentro de um beco sem saída (sempre) persuasivo. No caso particular dos jogos \& exercícios eu-você, desempenho o duplo papel de propositor e ator - o que significa atuar tanto como sujeito quanto como objeto, em relação a mim mesmo e aos outros. Entramos aqui em uma discussão relativa ao campo da arte: a dinâmica entre nós e eles é tida como o padrão habitual através do qual o papel e a imagem do artista são negociados em nossa sociedade, em termos de estruturas institucionais e de mercado. Comumente, os artistas entram nesse campo através de um processo de transformação, em que abandonam progressivamente seu estado estrangeiro para habitar a moldura institucional - essa condição convencional reduzida não representa uma norma, mas um conjunto de traços re-territorializantes que alimentam a arte, tornando-a um lugar com limites seguros e garantidos em nossa sociedade. Essa é uma óbvia supersimplificação, ligada a estereótipos do senso comum. Uma perspectiva mais interessante pode ser buscada em termos do 
que foi mencionado acima como 'processo de passagem'. O artista contemporâneo rompe as linhas que vão diretamente de eles para nós, tornando essa conexão complexa, isto é, enfatizando entre suas características o fluxo contínuo entre indivíduos, grupos, coletivos e instituições - indo e vindo de um para outro, desempenhando papéis simultâneos e ocupando mais de uma posição ao mesmo tempo. Enquanto o artista superinstitucionalizado é alguém preso à linearidade |eles $\rightarrow$ nós|, o artista interessante de hoje se moveria no duplo sentido nós $\leftrightarrow$ eles, encontrando a sua singularidade não em cada extremo, mas no conjunto de múltiplas relações envolvidas em diversos processos de transformação.

Um último comentário sobre os jogos \& exercícios eu-você: se observarmos um membro do grupo individualmente, poderemos trazer mais algumas pistas para a nossa discussão no que diz respeito à relação entre os pronomes pessoais. No sentido em que criam padrões para o grupo, funcionando como uma espécie de identificador, podemos considerar as camisas como uniformes - elas dão visibilidade aos processos e experiências conduzidos coletivamente. É possível dizer, em uma breve mirada, quem faz ou não faz parte do grupo em atividade - o observador vê se o grupo está disperso no local ou se ele se concentra em torno de um lugar com os participantes reunidos (ex: agrupamentos de vários eus e vocês). Como em qualquer grupo, podemos dirigir a atenção para indivíduos isolados que, com suas próprias características, compartilham, nesse momento específico, de certas expectativas e possibilidades de ação. Um único indivíduo vestido com uma camisa 'eu' (vermelha) ou 'você' (amarela) incorpora, na verdade, uma 'cadeia de pronomes' com múltiplas camadas: eu (ou você) como sua interface externa (a camisa), seguido de um ele ou ela (aquele que veste a camisa: "Alan ou Jane?"); e uma terceira camada composta pelo sujeito que atua, eu ("eu sou eu, eu sou você"). Essas várias camadas fazem emergir (tornam visível) o complexo circuito incorporado pelo participante dos jogos \& exercícios eu-você, indicando como as camisas são apenas a camada mais externa de um fluxo de significantes que é disparado de forma nova. Se considerarmos:

$$
e u\left(\frac{e l a}{e u}\right)
$$


um único indivíduo com uma camisa vermelha

e

$$
\operatorname{você}\left(\frac{\mathrm{ele}}{\mathrm{eu}}\right)
$$

um único indivíduo com uma camisa amarela,

então poderemos re-trabalhar as fórmulas nós e eles apresentadas anteriormente:

$$
\begin{gathered}
n\left[\mathrm{eu}\left(\frac{\mathrm{ela}}{\mathrm{eu}}\right)+\operatorname{você}\left(\frac{\mathrm{ele}}{\mathrm{eu}}\right)+\mathrm{eu}\left(\frac{\mathrm{ele}}{\mathrm{eu}}\right)+\operatorname{você}\left(\frac{\mathrm{ela}}{\mathrm{eu}}\right)\right]=\text { nós } \\
\mathrm{eu}-n\left[\mathrm{eu}\left(\frac{\mathrm{ela}}{\mathrm{eu}}\right)+\operatorname{você}\left(\frac{\mathrm{ele}}{\mathrm{eu}}\right)+\mathrm{eu}\left(\frac{\mathrm{ele}}{\mathrm{eu}}\right)+\operatorname{você}\left(\frac{\mathrm{ela}}{\mathrm{eu}}\right)\right]=\text { eles }
\end{gathered}
$$

Como resultado, a condição de estar com ou sem o grupo torna-se muito mais misturada, envolvendo pelo menos três estados:

(1) a estrutura pessoal do sujeito, experienciada como uma redução de seu espaço privado em relação ao grupo: eu $\leftrightarrow$ nós

(2) a condição de ser um objeto para os que o observam, isto é, um ele ou ela atuando e em movimento: ela, ele $\leftrightarrow$ eles;

(3) a condição de ser portador de um identificador externo (as camisas eu e você ) que marcam o indivíduo como membro do grupo atuante:

$e u$, você $\leftrightarrow$ nós, eles.

Assim, os jogos \& exercícios eu-você são planejados para proporcionar, tanto a mim quanto aos participantes, uma investigação intensiva sobre os 'pronomes em deslocamento'. Em termos de dinâmica de grupo - o padrão comum nós e eles é retrabalhado e expandido através desse processo. 


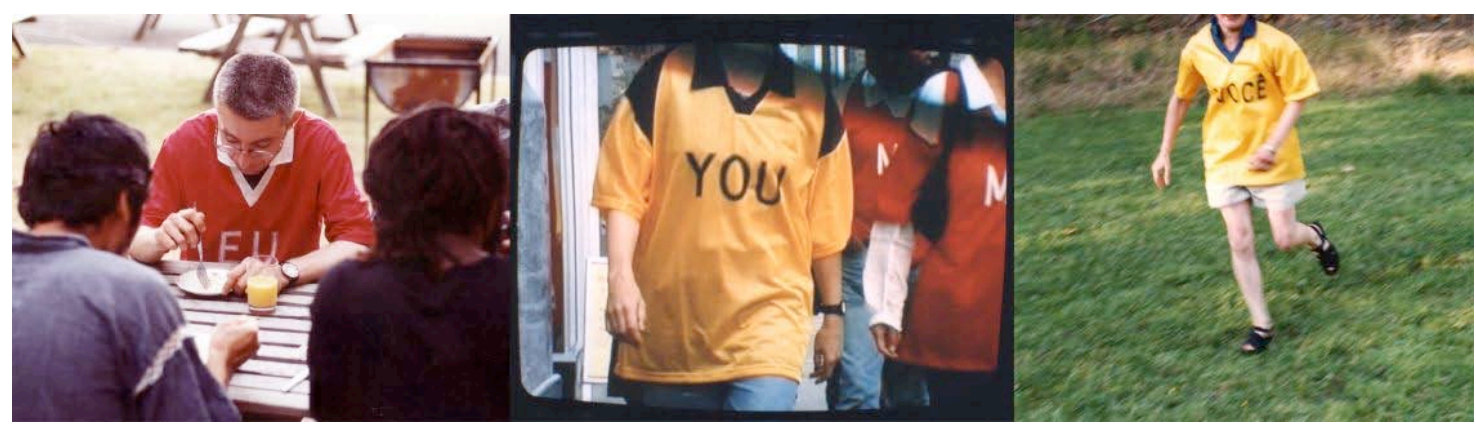

eu-você, serigrafia, camisas, jogos, exercícios. realizado no País de Gales, Grã-Bretanha, Brasil ,1999.

\section{2. superpronome}

Outro tópico interessante para discutirmos aqui é a criação do superpronome. Começando como uma proposição em que as palavras 'eu' e 'você' foram colocadas lado a lado sem nenhuma estrutura conectiva (hífen ou espaço) entre elas, o superpronome pretende ser um novo pronome que inclui ao mesmo tempo o sujeito (eu) e o objeto (você). Pode ser usado em ambas as direções, formando duas possibilidades diferentes de partículas verbais: euvocê, vocêeu. Em um enunciado recente, o superpronome foi assim delineado:

convergência de pronomes pessoais

em uma única palavra.

euvocê, vocêeu

mistura, hibridização, contaminação recíproca

de um pelo outro, de eu por você, de você por eu, numa só coisa. êxtase do objeto,

síntese ideal do desejo.

instrumento de negociação para ações

de uma alteridade incorporada, em fuga.

Tal palavra refere-se a enunciados relacionados a circunstâncias em que é importante enfatizar os vínculos (afetos, membranas, interfaces) entre sujeito e objeto, revelando o quanto já há de alteridade instalada na matéria constitutiva do sujeito. Os superpronomes seguem a famosa proposição de Rimbaud 'Je est un 
autre', reduzindo-a a uma forma mais compacta. Seria necessário desenvolver posteriormente o uso do superpronome em frases como "euvocê estou indo embora", "vocêeu venha mais perto", etc, para provocar sua presença efetiva e senti-la no uso cotidiano da língua. Inseri-los no discurso é promover uma intervenção na linguagem, introduzindo significados que não poderiam ser articulados antes. Em termos da dinâmica nós-eles, como poderemos localizar os superpronomes? Com certeza, é algo que ainda deve ser realizado. Somente através do seu uso em ações e proposições concretas que as sutis conexões - que ligariam o aglomerado sujeito-objeto aos processos de agrupamento e desagrupamento - podem ser indicadas. Na verdade, o superpronome parece ser um grupo em si, em tamanho mínimo: não que as partículas euvocê ou vocêeu correspondam a dois indivíduos, mas que funcionam naquele campo de significado que considera impossível desenvolver um sujeito singular sem a presença intensiva do outro. Há uma lacuna entre euvocê $\leftrightarrow$ vocêeu e nós $\leftrightarrow$ eles - o primeiro parece circular e tautológico, o segundo indica um processo entre "concentrado" e "disperso" (algo como um arco) que se assemelha a ordem $\leftrightarrow$ desordem (entropia). Assim, parece que duas conexões diferentes e independentes deveriam ser estabelecidas, colocando os superpronomes em contato direto com nós e eles, separadamente. A fórmula nós $\leftrightarrow$ eles será, então, re-mixada:

$$
\text { (euvocê, vocêeu } \leftrightarrow \text { nós) } \leftrightarrow \text { (euvocê, vocêeu } \leftrightarrow \text { eles) }
$$

Quando o superpronome é submetido a forças externas, estranhas à sua organização autocontida, ele é ao mesmo tempo exposto aos seus limites (o círculo) e expandido a uma gama de outras possibilidades (agrupamentos, desagrupamentos). Espero que esse processo encontre seu próprio modo de realizar-se, inteira ou parcialmente, significando que o superpronome irá progressivamente negociar o seu modo de ação no campo das manobras coletivas. 


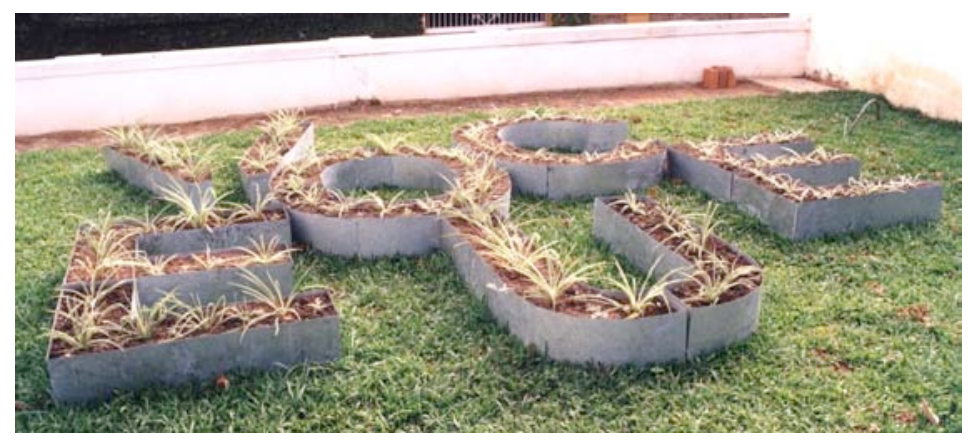

superpronome, metal, terra, plantas, 2000.

\section{3. nós nós}

Próxima parada: um breve parágrafo para descrever o enunciado nós nós. O duplo significado encontrado na palavra nós (enquanto pronome ou ponto de entrelaçamento) estabelece uma conexão entre o grupo ou coletivo e a idéia de rede ou teia. Revela, assim, a noção de que a formação de grupos parte de um funcionamento em rede, multiplicando um circuito através da operação sem fim de conexão, desconexão e re-conexão. Se o grupo é concebido como um circuito, cada nó não é um só indivíduo, mas um outro grupo em si - a estrutura fractal é evidente. Singularidade e grupo são a mesma coisa, diferindo somente em escala (um circuito sempre pode ter a sua escala alterada, ajustada) e funcionalidade. O enunciado nós nós foi primeiramente apresentado na forma de um elemento impresso, o adesivomanifesto nós nós, distribuído em vários lugares e pontos de encontro no Rio de Janeiro e em São Paulo. Trata-se de um manifesto afirmativo e altamente inclusivo, que não menciona eles: não que tente evitar os outros, mas indica que o problema da alteridade é tratado de modo diferente. Do ponto de vista de uma estrutura de circuito - que existe como conseqüência de seu "desejo de conectar" - o outro só existe durante o tempo que precede o ato de ligação. Dura somente a fração de tempo necessária para realizar a conexão. Para nós nós, se eles brilhar será imediatamente incorporado ao circuito - eles como um processo evanescente em direção a nós. O perigo reside em não aceitar as forças externas como verdadeiramente constitutivas dos processos de transformação, reduzindo-as a meras estruturas reconhecíveis de acoplagem. O interessante é assumir que as 
técnicas de sobrevivência dependem completamente do processo de ligar sucessivamente mais e mais nós. Voracidade conectiva.

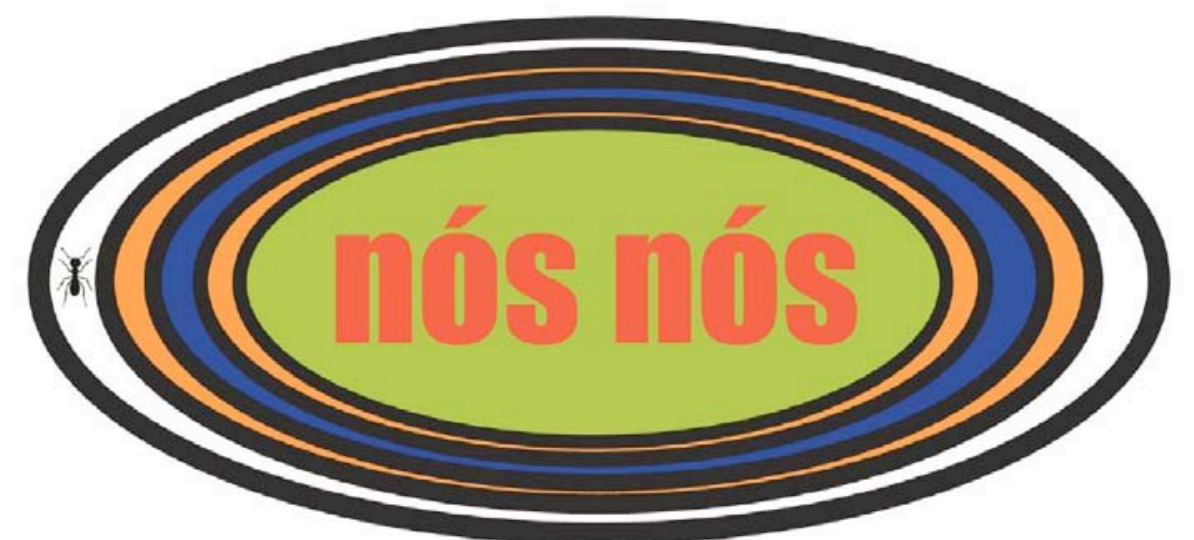

adesivo-manifesto nós nós, 2002. A formiga indica o 'coletivo formigueiro', um grupo dedicado ao ativismo midiático formado por artistas, videomakers, cineastas, curadores e escritores que trabalham em São Paulo e no Rio de Janeiro.

\section{4. você gostaria?}

Em 1994 iniciei o projeto chamado Você gostaria de participar de uma experiência artística? Tal projeto obteve êxito, e desde então está em andamento contínuo, tendo completado já seu décimo aniversário. O projeto opera a partir de um objeto em aço esmaltado, oferecido ao participante para ser levado para casa por um mês, para a realização de uma 'experiência artística'. Peço ao participante que a documentação (incluindo vídeos, fotos, objetos, depoimentos, etc.) seja enviada a mim, para que eu a publique na forma de website, livro ou exposição. Desde o início do projeto, pouco mais de 30 participantes (alguns deles enquanto grupos) têm produzido diversas 'experiências' e enviado uma documentação vasta e interessante. $\mathrm{O}$ objeto em si, e às vezes material a ele relacionado - como pôsteres ou panfletos - tem circulado por várias cidades, de Londres e San Sebastián (Espanha) ao Rio de Janeiro, Vitória, Brasília, São Paulo, Porto Alegre e Florianópolis, entre outras localidades brasileiras. É claramente um trabalho-em$\mathrm{curso}^{7}$, na medida em que encontra seu percurso no próprio processo que está

\footnotetext{
${ }^{7}$ No original, work-in-progress. A opção por "trabalho-em-curso", segue sugestão da artista argentina Alejandra Riera, que adota em francês a expressão "travail-en-cours". Trata-se de uma atualização do termo, mantendo a noção de um caráter contínuo da investigação artística, eliminando porém a noção
} 
sendo desenvolvido e que virtualmente não tem fim, já que sua continuidade não depende do tempo de vida do autor (o objeto não é concebido como uma peça original única, já que um ou vários novos objetos podem ser produzidos cada vez que for necessário).

Uma das características mais interessantes de Você gostaria de participar de uma experiência artística? reside em como o projeto faz da autoria um problema, provendo um modo de incluir o participante como um colaborador decisivo. $\mathrm{Na}$ verdade, sem os participantes o trabalho existe somente como projeto potencial (objetos, diagramas, panfletos); logo, sua efetiva contribuição, através da aceitação em planejar e executar uma experiência artística, é decisiva. Os vídeos e fotos, enviados a mim pelos participantes, são meus ou deles? Embora se trate de minha proposta e meu objeto, os documentos e experiências são concebidos e produzidos por eles. Esse deslocamento me interessa e agrada muito. É, claramente, uma situação de autoria compartilhada em que o participante é inteiramente responsável pelas decisões do quê e como irá fazer em relação à experiência proposta e ao seu registro. O que eu faço, além de coletar a documentação e planejar como publicá-la e exibi-la? Considero importante contatar (e-mail, cartas, telefone) os participantes no início e no final das suas experiências, fazendo-me presente no sentido de demonstrar interesse, estando atento ao que ocorre e ao deslocamento do objeto e enviando alguma documentação quando solicitado. O que me surpreende é que, quando o projeto se iniciou, era necessário persistir e fazer um esforço significativo que envolvia exposições, palestras e contatos pessoais - para conseguir a aceitação e colaboração das pessoas. No entanto, desde o ano 2000 o processo reverteu-se: o objeto chega aos participantes antes de mim, uma vez que os participantes mesmos estão passando-o adiante para as pessoas que conhecem. Agora me encontro na situação interessante de conhecer pessoas através do objeto, o que é muito prazeroso em termos de acesso a outras pessoas e circuitos. 
O projeto Você gostaria de participar de uma experiência artística? poderia ser descrito como possuindo dois sujeitos para um objeto: sujeito (autor) $\rightarrow$ objeto $\leftarrow$ sujeito (participante). No entanto, quando convido alguém para participar, o colaborador (você) é entendido como um objeto para a experiência que estou propondo. A situação é revertida quando o participante termina a sua proposta e me envia o objeto de volta, acompanhado da documentação. Nesse momento, estou localizado na posição de objeto de sua ação. Portanto, se considerado a partir do ponto de vista do autor ou do participante, o projeto poderia ser descrito como tendo um sujeito e dois objetos: sujeito (autor) $\rightarrow$ objeto $\rightarrow$ objeto (participante) ou sujeito (participante) $\rightarrow$ objeto $\rightarrow$ objeto (autor). Essa condição de 'duplo objeto' não implica em uma equivalência entre os dois termos. Há aqui uma assimetria básica, representada pelas diferenças implícitas no par autor-participante. A experiência trazida por Você gostaria de participar de uma experiência artística? obtém sua singular conquista não exatamente através da equivalência você = você, mas por meio da diferença assimétrica você $x$ você (' $x$ ' pode ser lido como versus ou vezes), produzindo a dinâmica necessária que torna possível a sua continuidade a cada nova colaboração. Considerado enquanto um projeto que deve cuidadosamente manter as suas ligações internas com potencial suficiente para sustentar mais e mais encontros e possibilidades em aberto, a condição de duplo objeto pode ser colocada em uma fórmula bastante compacta, conforme segue:

\section{(você) $)^{2}$}

Nesse sentido, é através da ênfase decisiva no duplo potencial do objeto (que pode ser facilmente compreendido como um investimento no duplo potencial do outro) que Você gostaria de participar de uma experiência artística? contribui para a discussão proposta aqui. $\mathrm{O}$ aspecto traiçoeiro presente no padrão nós e eles reside no sutil esquema de obscurecimento, ou mesmo ocultamento, da presença e papel do outro em seu (nosso e deles) processo constitutivo.

Propus aqui algumas estratégias de intervenção em uma condição-padrão de exclusão, buscando diferentes formas de re-instaurar dinâmicas que possam deflagrar os efeitos próprios produzidos pela alteridade em dinâmicas de grupo, na 
linguagem e em outros processos de produção de sentido. Sem tais práticas de abordagem desse espaço 'entre', com o objetivo de criar fluxo, movimento, desvio e fuga, o risco é que nós e eles se aproximem cada vez mais entre si, resultando em nóseles - ou seja, o "todo ilimitado" (existe algo além de nós e eles?) sem intervalo, mediação, distinção e diferença. É sempre interessante abrir as coisas através de gestos produtivos, como os jogos e exercícios propostos aqui - estas são as passagens por onde você e eu podem entrar.

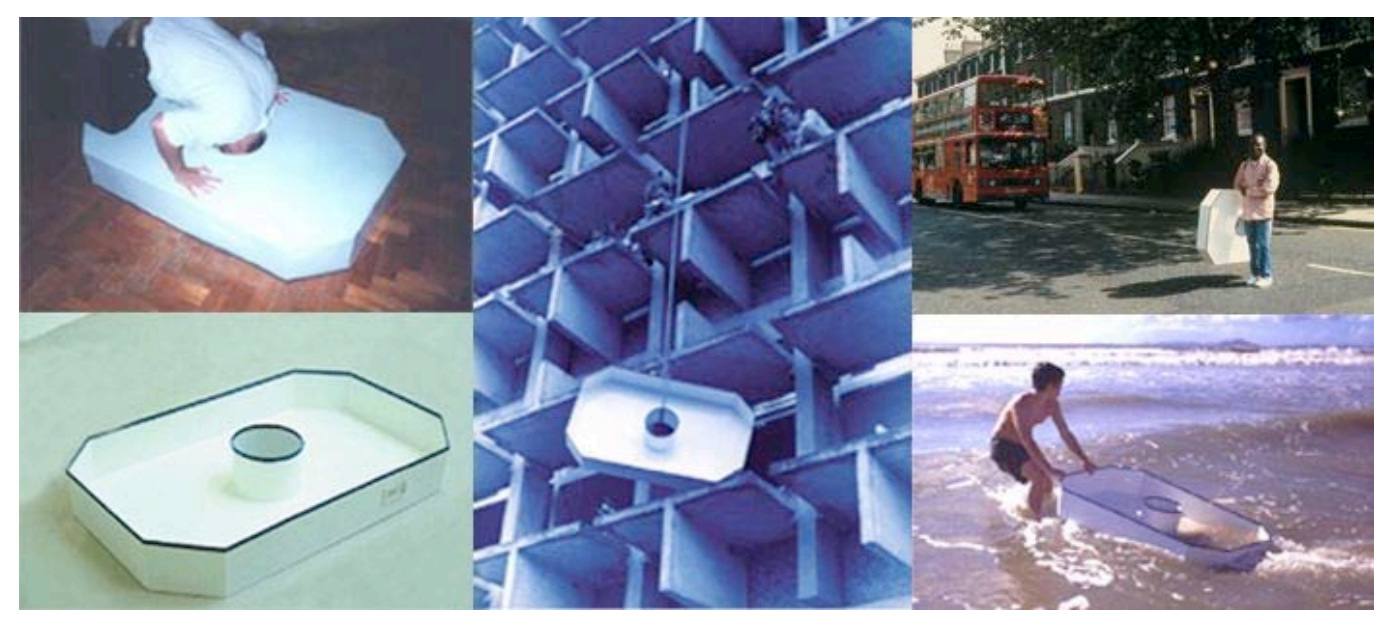

Você gostaria de participar de uma experiência artísitca?, projeto em andamento desde 1994. A partir do alto, à esquerda, experiências no Rio de Janeiro, Brasília, Londres e Verão Vermelho. 


\section{AMO OS ARTISTAS-ETC ${ }^{8}$}

(2004)

\section{ADVERTÊNCIA:}

Atenção para esta distinção de vocabulário:

(1) Quando um curador é curador em tempo integral, nós o chamaremos de curadorcurador;

quando o curador questiona a natureza e a função de seu papel como curador, escreveremos 'curador-etc' (de modo que poderemos imaginar diversas categorias, tais como curador-escritor, curador-diretor, curador-artista, curador-produtor, curador-agenciador, curador-engenheiro, curador-doutor, etc);

(2) Quando um artista é artista em tempo integral, nós o chamaremos de 'artistaartista;

quando o artista questiona a natureza e a função de seu papel como artista, escreveremos 'artista-etc' (de modo que poderemos imaginar diversas categorias: artista-curador, artista-escritor, artista-ativista, artista-produtor, artista-agenciador, artista-teórico, artista-terapeuta, artista-professor, artista-químico, etc);

O enunciado acima pressupõe que o 'curador-curador' (ou mesmo o 'curadorartista') trabalha de modo diferente do 'artista-curador'. É em torno deste ponto que gostaria de comentar a afirmação proposta: "A próxima Documenta deveria ser curada por um artista".

Amo os artistas-etc.

Talvez por que me considere um deles.

Artistas-etc não se moldam facilmente em categorias e tampouco são facilmente embalados para seguir viagens pelo mundo, devido, na maioria das vezes, a comprometimentos diversos que revelam não apenas uma agenda cheia mas sobretudo fortes ligações com os circuitos locais em que estão inseridos. Vejo o 'artista-etc' como um desenvolvimento e extensão do 'artista-multimídia' que emergiu em meados dos anos 1970, combinando o 'artista-intermídia' fluxus com o 'artistaconceitual' - hoje, a maioria dos artistas (digo, aqueles interessantes...) poderia ser

\footnotetext{
8 "I love etc-artists" foi publicado originalmente em inglês, como parte do projeto The next Documenta should be curated by an artist, posteriormente transformado em livro (Frankfurt, Revolver Books, 2004). Sob curadoria e organização de Jens Hoffmann, 31 artistas foram convidados a comentar a proposição sugerida pelo curador, de modo a investigar as relações entre práticas artísticas e curatoriais. A versão em português aqui apresentada foi realizada pelo autor para esta edição. Original disponível on-line em http://www.e-flux.com .
} 
considerada como 'artistas-multimídia', embora, por 'razões de discurso', estes sejam referidos somente como 'artistas' pela mídia e literatura especializadas. 'Artista' é um termo cujo sentido se sobre-compõe em múltiplas camadas (o mesmo se passa com 'arte' e demais palavras relacionadas, tais como 'pintura', 'desenho', 'objeto'), isto é, ainda que seja escrito sempre da mesma maneira, possui diversos significados ao mesmo tempo. Sua multiplicidade, entretanto, é invariavelmente reduzida apenas a um sentido dominante e único (com a óbvia colaboração de uma maioria de leitores conformados e conformistas). Logo, é sempre necessário operar distinções de vocabulário. O 'artista-etc' traz ainda para o primeiro plano conexões entre arte\&vida (o 'an-artista' de Kaprow) e arte\&comunidades, abrindo caminho para a rica e curiosa mistura entre singularidade e acaso, diferenças culturais e sociais, e o pensamento. Se a próxima Documenta for curada por um artista, devemos esperar encontrar um artista-etc trabalhando como artista-curador.

Quando artistas realizam curadorias, não podem evitar a combinação de suas investigações artísticas com o projeto curatorial proposto: para mim, esta é sua força e singularidade particulares, quando em tal engajamento. O evento terá a oportunidade de mostrar-se claramente estruturado em rede de nós próximos, aumentando a circulação de energia 'afetiva' e 'sensorial' - um fluxo que o campo da arte tem procurado administrar em termos de sua própria economia e maleabilidade.

Se um artista-curador pretender dirigir/curar/planejar o assim chamado 'maior evento de arte contemporânea do circuito de arte do Ocidente', ele ou ela certamente terá que incluir, entre os diversos tipos de artistas (com forte simpatia pelos artistas-etc), pensadores contemporâneos de variadas disciplinas (para os críticos de arte: "coloque-se como um pensador-sensorial; caso contrário, você não existe") - todo um conjunto de não-artistas, tais como pessoas trabalhando em qualquer ocupação ou campo de pesquisa, em qualquer lugar do mundo. Essas pessoas não estariam produzindo arte, mas envolvidas com os artistas e seus trabalhos em um fórum permanente para produção de pensamento em tempo real (por bem mais que cem dias), construindo em conjunto atos sensoriais provocativos (SPACTs - Sensorial Provocative Acts). Aqui, suporte digital seria fundamental. Com tal dinâmica, quem se importará com o 'público'? O evento não estaria com as portas abertas, tendo optado por voltar-se para 'consumo interno' - este autofechamento deve ser compreendido como o reconhecimento da falência da 'esfera pública' e sua transição para algum tipo de arena pós-pública (a linha diagramática amizadecoletivo-multidão-comunidade), gesto a ser assumido como provocação necessária 
com o objetivo de buscar novas formas de relacionamento com a audiência. Queremos que os visitantes, que efetivamente comparecerem, sejam sujeitos de um processo de transformação durante o (e depois do) evento, desenvolvendo algum tipo de responsabilidade e compromisso em relação a ele. Como proposta final, a Documenta deveria deixar a cidade de Kassel e iniciar uma turnê mundial, passando seis meses em algumas cidades dentro dos cinco continentes, sendo coordenada por equipes locais de artistas-etc. Quando enfim retornar novamente ao seu lugar inicial (voltará para um local denominado 'origem'?), haverá material suficiente para uma série de filmes-documentários acerca do papel a ser desempenhado pela arte contemporânea no mundo mutante da atualidade. Para serem apreciados na segurança do lar, através da TV, pelas famílias do planeta.

Amo os artistas-etc.

Talvez porque me considere um deles, e não é correto odiar a mim mesmo. 
psiu-ei-oi-olá-não ${ }^{[1]}$

(2004)

psiu...

psiu...

psiu...

ei, oi, olá, olhe para cá - olhe...

veja - olhe - preste atenção

repare - não há nada

nada para ver

psiu - ei - psiu - aqui

psiu -

olhe...

escutar - olhar para - corpo voltado para - sorrir para - falar a

dirigir-se a - desejos expressos - dar ou lançar algo - fazer contato corporal fazer pedidos - fazer perguntas pessoais - demonstrar habilidade exibir-se - ficar perto - reações afetivas ${ }^{[2]}$

sossegue - fique sossegada

repare

olhe aqui - bem aqui -

preste atenção - bem distraída

não há nada

não há nada para ver

ei - psiu...

psiu...

olhe aqui

escutar - olhar para - corpo voltado para - sorrir para - falar a

dirigir-se a - desejos expressos - dar ou lançar algo - fazer contato corporal fazer pedidos - fazer perguntas pessoais - demonstrar habilidade exibir-se - ficar perto - reações afetivas

ah! agora -

é agora - já - neste instante -

agora - veja -

bem aqui - bem aqui!

aqui e agora -

ah!

assim - assim - bem assim

vem - venha - pode vir

assim - aqui e agora 
venha aqui - bem aqui

olhe - venha para mim

psiu...

psiu...

aqui e agora - já -

neste instante

pode ver

sim

não - não há nada

não

escutar - olhar para - corpo voltado para - sorrir para - falar a

dirigir-se a - desejos expressos - dar ou lançar algo - fazer contato corporal fazer pedidos - fazer perguntas pessoais - demonstrar habilidade

exibir-se - ficar perto - reações afetivas

esqueci de dizer

esqueci - olhe - olhe bem aqui -

espere - espere - esqueci de dizer

já não compreendo

venha aqui

psiu... - não quero e não compreendo

eu posso

olhe - olhe para cá - bem aqui -

nada mais

não vejo nada - nada

olhe para cá - aqui - bem aqui

não há nada

veja...

escutar - olhar para - corpo voltado para - sorrir para - falar a

dirigir-se a - desejos expressos - dar ou lançar algo - fazer contato corporal fazer pedidos - fazer perguntas pessoais - demonstrar habilidade

exibir-se - ficar perto - reações afetivas

não

não me interessa - não quero

não quero saber - qualquer coisa

nada quero saber

fique por aí - você

você - eu - você - eu - você

fique - não diga nada

não quero ver 
não

escutar - olhar para - corpo voltado para - sorrir para - falar a

dirigir-se a - desejos expressos - dar ou lançar algo - fazer contato corporal

fazer pedidos - fazer perguntas pessoais - demonstrar habilidade

exibir-se - ficar perto - reações afetivas

psiu...

psiu...

psiu...

[1] Este texto integra a exposição "psiu-ei-oi-olá-não", apresentada na Gentil Carioca, Rio de Janeiro, em novembro e dezembro de 2004. Foi lido por telefone público, do Rio de Janeiro, em ligação à cobrar, na abertura da mostra "Vol.", Galeria Vermelho, São Paulo, em novembro de 2004.

[2] Lista de comportamentos extraídos do experimento "Ação em Relação ao Extranho", de Kurt Lewin, conforme tabela apresentada no artigo "Sinopse das investigações experimentais". 


\section{roteiro para sistema-cinema}

(2005)

sistema-cinema é o nome de um procedimento de captação, transmissão e gravação de imagens, em tempo real, que tenho utilizado, a partir de 2001, em conjunto com a construção de instalações, intervenções e objetos: desde as primeiras experiências, a vontade foi de adicionar uma camada a mais aos procedimentos de construção e instauração do projeto - como se já houvesse algo nos trabalhos que fosse da ordem do cinema e que seria necessário externalizar, tornar mais claro, somando presença. Foi assim que decidi adotar um conjunto simples de equipamentos, típicos da construção de um ambiente de imagem-vídeo em circuito-fechado:

microcâmeras, seqüencial, monitor, vídeocassete. Um certo regime de funcionamento e economia da imagem é instaurado, junto ao espaço delimitado e fronteiriço da instalação: (1) as câmeras abrem-se para o ambiente, a partir de certos enquadramentos fixos; (2) as imagens são enviadas ao monitor, mapeando certas possibilidades de ação frente àquele ambiente; (3) imagens em fluxo contínuo, uma após a outra, são reguladas para se repetirem em intervalos constantes de cerca de 5 segundos; (4) as seqüências são gravadas em vídeo, para arquivamento e utilização posterior.

Nestes 4 passos de implementação do dispositivo, estão indicadas já algumas de suas principais ações e efeitos - seu funcionamento, seu programa: (a) prática de enquadramento para construir outra apreensão do espaço: a instalação passa a dispor tanto de regiões intensificadas pela presença da câmera ali apontada, quanto de regiões de sombra, avessas à captação de imagem - estimula-se assim o efeito disjuntivo entre olho-corpo / olho-câmera, indicando problematizações de uma política da percepção; (b) transmissão em tempo-real em que o próprio local onde são geradas as imagens as recebe de volta, em incessante continuidade descontínua: recurso não-tautológico que enfatiza a situação quasi-performática compulsória, em que o corpo é a mediação principal para o estabelecimento do aqui\&agora da instalação; (c) montagem circular por meio de ritmo seqüencial em 
que as imagens se sucedem a partir de padrões fixos pré-estabelecidos: a importância do núcleo rítmico pulsante que erotiza o ambiente (indicando um 'pensamento-ambiente'), conduzindo à pergunta: "será que tudo o que eventualmente aconteça aqui em torno jamais perturbará tal ritmo?"; (d) gravação e arquivamento para posterior utilização sob outras formas videográficas, que reinventarão o espaço capturado para o olhar de alguém não presente à situação inicial: para além do registro, o que se assume é uma vontade voraz de montagem para que se produza mais um acontecimento que multiplique e diversifique a forma inicial, através de nova mediação instauradora de sua própria continuidade.

Cinema não toma parte aqui enquanto posição hierárquica superior frente ao processo, com ambição de estabelecer-se como 'produto final' - antes, sua presença se insinua no mesmo plano de igualdade em que ocorre sua própria desmontagem em 4 etapas. Logo, sistema-cinema se caracteriza por uma pragmática (sistema) que atende a um determinado emprego, a uma utilização que busca trazer potência relacional extra a um projeto artístico em pleno andamento e funcionamento, sintoma de alguns de seus traços constitutivos e estruturais.

sistema-cinema acopla-se ao projeto de trabalho em progresso NBP a partir de um elemento de mediação discursiva, composto em três blocos - transcrito abaixo -, que se quer instrumento de implantação das operações do tipo V.C.P. (Vivência Crítica Participante) $)^{9}$. O que se pretende é que o outro experiencie o projeto de trabalho em nível de campo sensível, mas que este jogo não se desincompatibilize da rede de produção discursiva, inauguradora também de uma espacialidade intensiva: sujeitos que se situem dentro da rede de relações instituída, mas que se potencializem para fora de si, na busca de conexões transformadoras.

\footnotetext{
${ }^{9}$ Ver: "Critical and Participatory 'Vivência', in Vivências: dialogues between the works of Brazilian artists from 1960s-2002, The New Art Gallery Walsall, Walsall, 2002; e "V.C.P. - Vivência Crítica Participante", Ars, São Paulo, Programa de Pós-Graduação em Artes Visuais, USP, no prelo. Tanto esta quanto as próximas referências remetem a textos do autor.
} 


\section{transatravessamento ${ }^{10}$}

aceleração positiva ou negativa: sua velocidade jamais será a mesma depois deste contato. Não se esqueça: "o pensamento é mais rápido que a velocidade da luz" (já foi dito). Sensorialidade como deslizamento entre o caótico e o prazeroso, tocando a superfície das coisas (ir e vir, ir e vir, ir e vir são parte do processo - ritmos oceânicos). Afetos criam ligações de seda com a força de cabos de aço: conexões, redes, teias e outras coisas trançadas imersas em tal vocabulário.

\section{adversa geléia ${ }^{11}$}

olhares para o entorno, despindo-se de alguns automatismos, aceitando a fluência de outros. Mergulhando no que imensamente nos escapa e resiste e é ao mesmo tempo estranhamente familiar: passando ao lado nos captura e transmite ao longe - sempre. Estado momentâneo quase chegando a ser junto comigo.

\section{artista-etc $^{12}$}

a imagem do que se faz misturando-se ao que não se faz; (des)construindo enquanto se aponta em mil direções e se apronta em prestações. Frágil resistência, sutil insistência: nunca apenas um lugar nem a mesma rotina de procedimentos; sempre as simultaneidades e o olhar magnético, a confiança no lugar. Compactação impossível do poético singular que escapa sempre, tudo arrastando em volta. Voraz. Contenção. Saltos.

Sistema-Cinema V.C.P. (Vivência Crítica Participante)

\footnotetext{
${ }^{10}$ Ver: "Módulo de Transatravessamento do artista-etc", in 25a Bienal de São Paulo - Iconografias Metropolitanas, São Paulo, Fundação Bienal, 2002, p. 46.

${ }^{11}$ Combinação das proposições "da adversidade vivemos" (Hélio Oiticica) e "geléia geral" (Décio Pignatari).

${ }^{12}$ Ver: "I love etc-artists" in The next Documenta should be curated by an artist, Frankfurt, Revolver Books, 2004.
} 
"O visitante, quando passa, é chamado insistentemente para aquele local (não há promessas), ao mesmo tempo em que sua sombra é promovida a entidade dinâmica, foco de resistência e mutabilidade, já não sendo mais a mesma." 
(a), (b), (c):

(2007)

No âmbito de um processo de negociação, os termos abaixo foram assinalados - o que implica no reforço da construção de um espaço de aceitação do outro, ao menos enquanto provocação viável que deve ser levada em conta se quisermos estabelecer a continuidade do contato. $E$ assim foi - sem que me esquecesse da necessidade de afirmar cada uma das frases: e, de fato, se a provocação (a) veio do participante [GPCl, setembro 1997], (b) e (c) associaram-se prontamente como elementos que reforçariam a resposta à provocação inicial. De certo modo, seriam as duas últimas - elementos que serviriam para trazer garantias maiores ao meu lado da negociação. Não é sempre assim? Quando tomamos o rumo do local de confronto (mesmo entre amigos queridos) procuramos não estar em situação que permitiria poucas manobras - algo como uma condução linear e absolutamente inflexível - mas sim abrigar a alegria serena e afirmativa que nos facilitaria recebêla(lo) em acolhimento generoso, onde o outro poderia inclusive exibir seus caprichos de excesso que estaríamos assim capazes de acolher. Então (b) nos permitiria (e não sou eu quem aqui se coloca e sim NBP) talvez supor que todo um campo de invisibilidades relacionais se constitui em torno do conjunto transportado pelo objeto de acrílico e também transportando-o (abrindo caminho) - fala-se aqui em transparência como maleabilidade, ambiência, configuração de um meio o qual facilita a travessia (ir, vir, deslizar, atravessar, fluir). Mas como acrescentar (c) neste conjunto? Claro que em termos de ação e funcionamento cada qual dos três tópicos pode ser ativado a qualquer tempo, sem hierarquização ou ordenamento préprogramado. E é neste âmbito que (c) insere-se no arranjo, afirmando características de uma inclusão cultural específica que anuncia referências assinaladas em mútua 'contração-transformativa' - de cunho de práticas e modalidades de ação cultural contundente (aqui: intervenção, resistência - geléia geral da adversidade da qual vivemos), simpáticas ao projeto em termos da região da qual parte e em relação às quais se quer inserido (isto é: recolhe elementos para sua própria aceleração). 
(a) espaço negativo

(b) transparentes conceitos

(c) geléia adversa

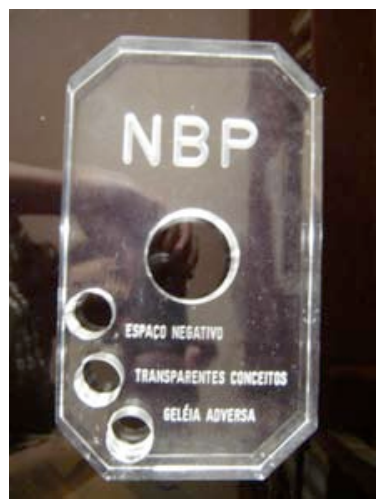


Você gostaria de participar de uma experiência artística? (1994-2008)

\section{VOCÊ}

(indivíduo, grupo ou coletivo)

gostaria de participar de uma experiência artística?

aceitaria levar para casa o objeto mostrado nesta fotografia?

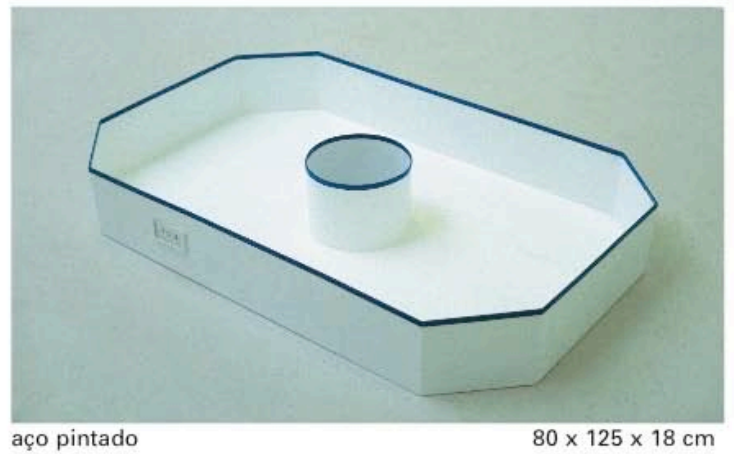

Isto é parte do projeto

NBP

Novas Bases para a Personalidade

que envolve idéias de participação e transformação

http://www.nbp.pro.br

uma investigação acerca do envolvimento do outro como participante em um conjunto de protocolos indicativos dos efeitos, condições e possibilidades da arte contemporânea 


\section{Você está convidado(a) a colaborar com}

\section{Você gostaria de participar de uma experiência artística?}

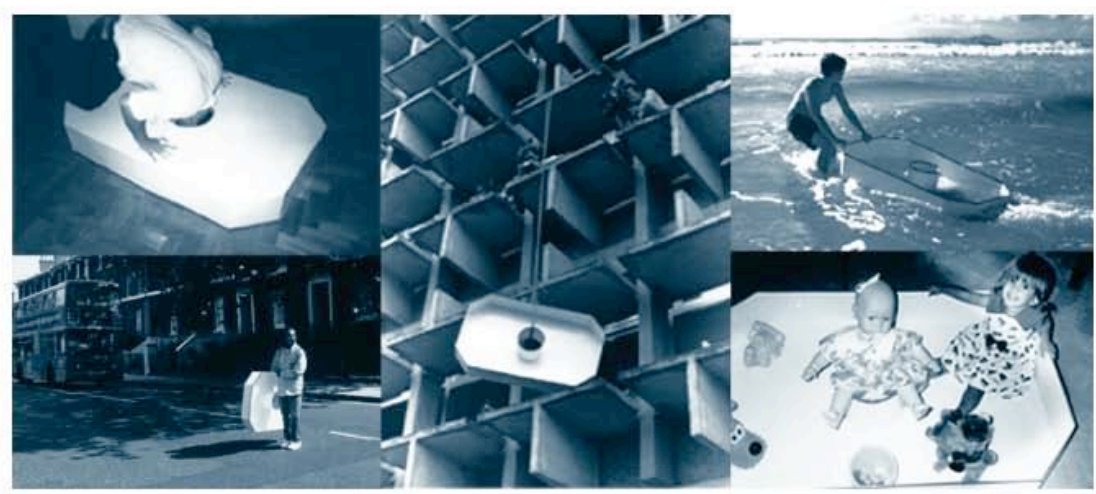

Basta aceitar utilizar, por um certo período, o objeto mostrado acima, para a realização de experiências.

Ele pode ser usado de diferentes modos e você pode fazer qualquer coisa com ele: use-o como quiser, da maneira que achar melhor.

O objeto carrega alguns conceitos e eu gostaria que você também os utilizasse. Apesar de invisíveis, eles são manipuláveis através do uso do objeto.

As experiências que você realizar tornam visíveis redes e estruturas de mediação, indicando a produção de diversos tipos de relaçōes e dados sensoriais: os conjuntos de linhas e diagramas, trazidos ao primeiro plano a partir de sua utilizaçăo, são mais importantes que o objeto.

Você documentará as experiências através de texto, fotografia, vídeo, som, objeto, etc, da maneira que achar mais adequada.

Envie e edite os registros diretamente em www.nbp.pro.br Suas experiências, junto daquelas realizadas por todos os participantes, estarão disponíveis ao público. 
O objeto utilizado em Você gostaria de participar de uma experiência artística? tem sua forma estabelecida de acordo com a forma específica NBP, desenhada para ser facilmente memorizável:

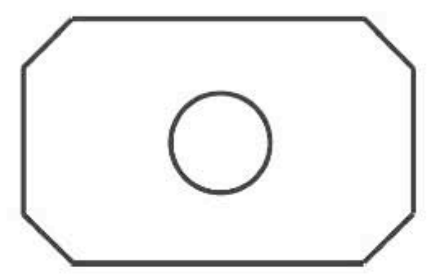

Ao experienciar qualquer trabalho da série NBP, você, ela ou ele saem com NBP e sua forma específica em seu corpo - uma modalidade de memória implantada ou artificial, como resultado de uma estratégia de contaminação sensorial subliminar.

NBP é um projeto em desenvolvimento contínuo,

iniciado em 1990, que conecta estratégias comunicacionais, arte contemporânea e perspectivas discursivas transdisciplinares.

NBP engloba a produção de imagens e conceitos, com o propósito de envolvê-lo(a) em um processo artístico.

NBP e sua forma específica são incorporados através da repetição e interação.

* você hibridiza com o objeto de arte

* você ativa os conceitos, produzindo outros, mais novos

Participando ativamente de uma experiência artística você pode transformar-se.

NBP e sua forma específica querem conduzi-lo(a) para um outro tipo de espaço, aquele que é produzido através do movimento. 
participantes:

Hogan Antia, SIM OU ZERO, Marcia Prezotti, Mara Perpétua, Rosana Paste, Dudu Candelot, Carlos Henrique dos Santos, Jacqueline de Azevedo Martins, Carlos Pontual, Brigida Baltar, A95, Grupo de Pesquisa Corpos Informáticos, Ralph Gehre, Santiago Canizares, Armando Coelho e Orlando Lemos, Enauro de Castro, Paulo Veiga Jordão, Divino Sobral, Tulio Tavares, Luciana Costa, Carla Zaccagnini, Anabela Santos, Marta Neves, Adriana Leão, Wilson Restinho, Jorge Menna Barreto, Fabiana Rossarola, Cristina Ribas, Cristiano Lenhardt, Patrícia Francisco, Elaine Tedesco, vaca amarela, Katia Bordinhão, Yiftah Pelled, Regina Melim, José Kinceler, Cássio Ferraz, Adriana Barreto, Kinder-und Jugendnetzwerk, Hand in Hand, Cultural Center Schlachthof, Dirk Schwarze, Offene Schule Waldau, Andrea Gerhardt, ?, Deborah Bruel, DEARTES - UFPR, Christian Kopetzki, FO/GO lab, Alan Dunn, Casa das Artes da Mangueira, Debora Santiago, Teresa Riccardi, MAC-Dragão do Mar, Laboratorio 060, Paulina Varas, Diego de Los Campos, Karina Forst, Jardim Miriam Arte Clube, Zukymavoy, Joze Barsi, Kurt U. Heldmann, Christine and Axel Knüppel, Hospiz Kassel, Kan-si, Casa das Artes de Vila Isabel, AIDS-Hilfe Kassel, magazine in situ, Atac Sezer, Betânia Silveira, Hans Moritz, Inst. for Contemporary Art / Dept. Architecture / TU Graz, Cecilia Bedê, Polonca Lovsin, Claudia Washington, Éverton Almeida e Roberta Benevit, Stephanie Nannen, Goto (e/ou), Dominio de Intercambio, Andrea Zierler, Mehtap Baydu, Grete-Unrein-Schule, Simone Barreto, Meiko Velez, Sebastian Hartmann, Adelaida Lelonek, Peter Wittke, Gabriela Schweigler, Maik Frommberg, Marina Stefan, Colégio dos Pescadores, Kunstleistungskurs Dom- und Lornsenschule, Julia Ziegenbein e Wanja Scholz, Nikolaus Meixner and hungry_body, WBG UNION e.G, Claudete Castro, TrAIN Transnational Art Identity and Nation, Silvia Litardi, Ações e Reações, Jaes Caicedo, Maria Helena Scaglia, Peter Kroeger Claussen,

\author{
Obrigado pela sua colaboração! \\ Ricardo Basbaum \\ nbp@nbp.pro.br
}


IMAGENS 


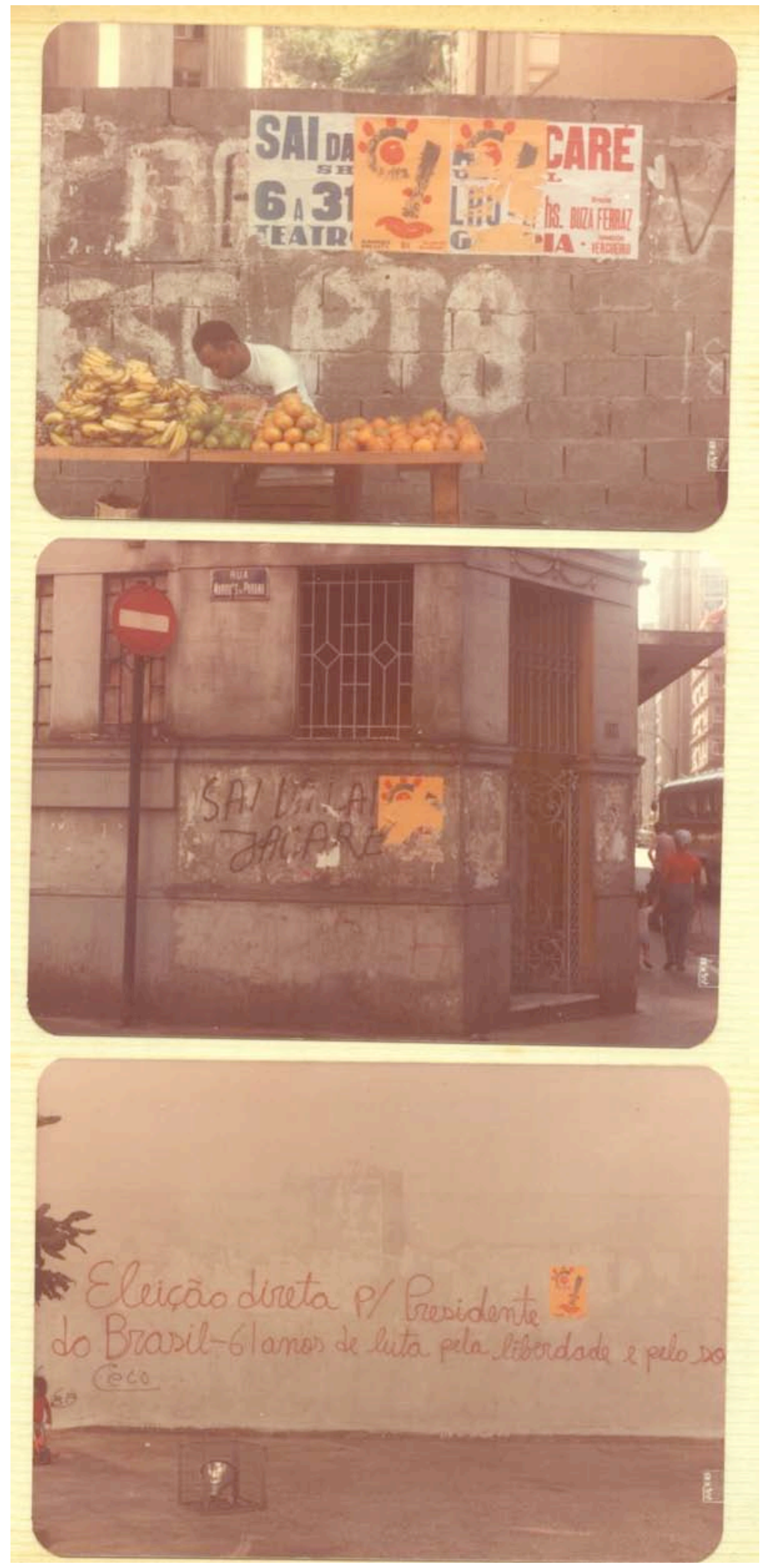

Figura 1 Dupla Especalizada, Pintura-Cartaz, 1983, cartaz em off-set, ruas do Rio de Janeiro 

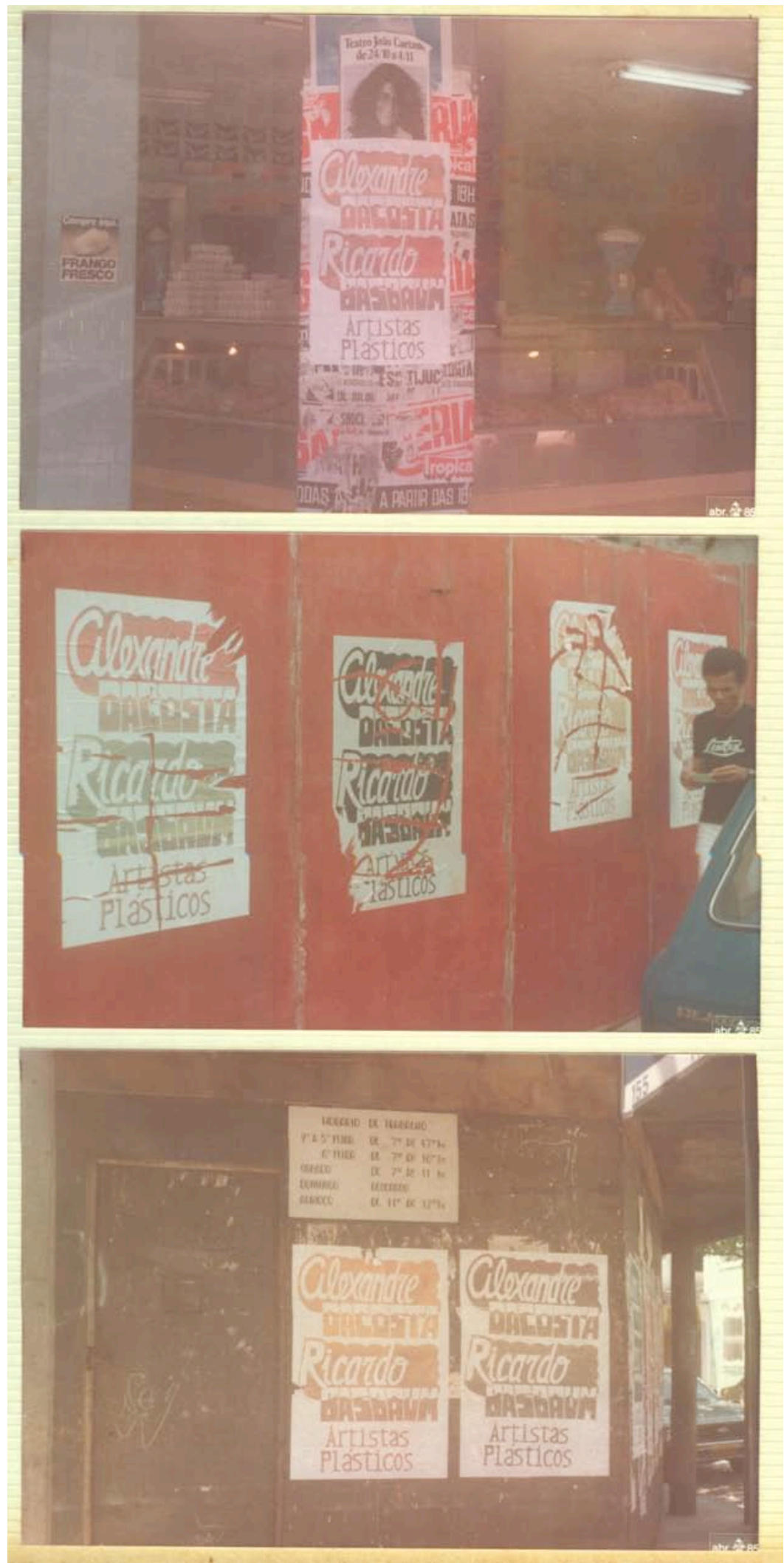

Figura 2 Dupla Especializada, Cartaz-Conceitual, 1984, cartaz em serigrafia, ruas do Rio de Janeiro 


\section{Alexandre Dacosta Ricardo Basbaum}

\section{ARTISTAS PLÁsticos}

- Dupla Especializada em Fazer Cartaz

e Intervir em Meios de Comunicação de Massa*

- O que é o SUCESSO?

- Sucesso é tornar-se um produto na sociedade de consumo

\section{ARTE É SUPERAR-TE}

- A propaganda é a alma do negócio

- E o corpo do negócio?

- O que é impresso é que fica na história

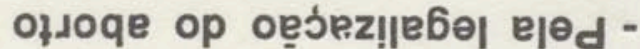

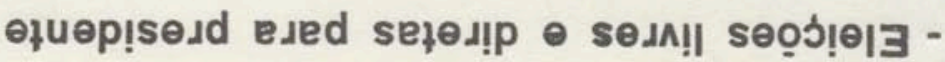

* Garçons nas horas vagas

- correspondência para o fà-clube -

Figura 3 Dupla Especializada, Filipeta-Manifesto, 1984, impressão em tipografia, distribuída nas ruas do Rio de Janeiro 


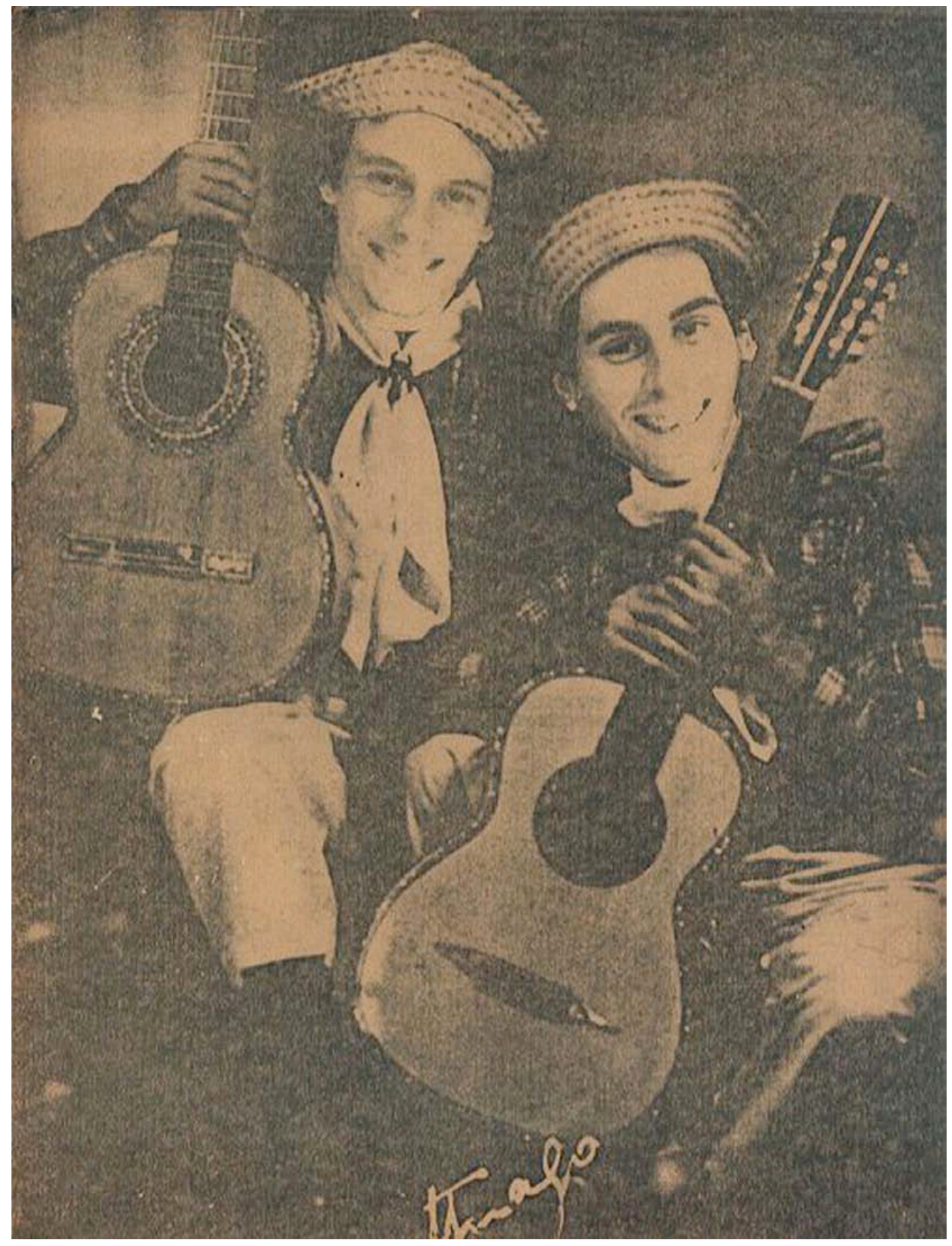

Figura 4 Dupla Especializada, montagem fotográfica, 1985. 


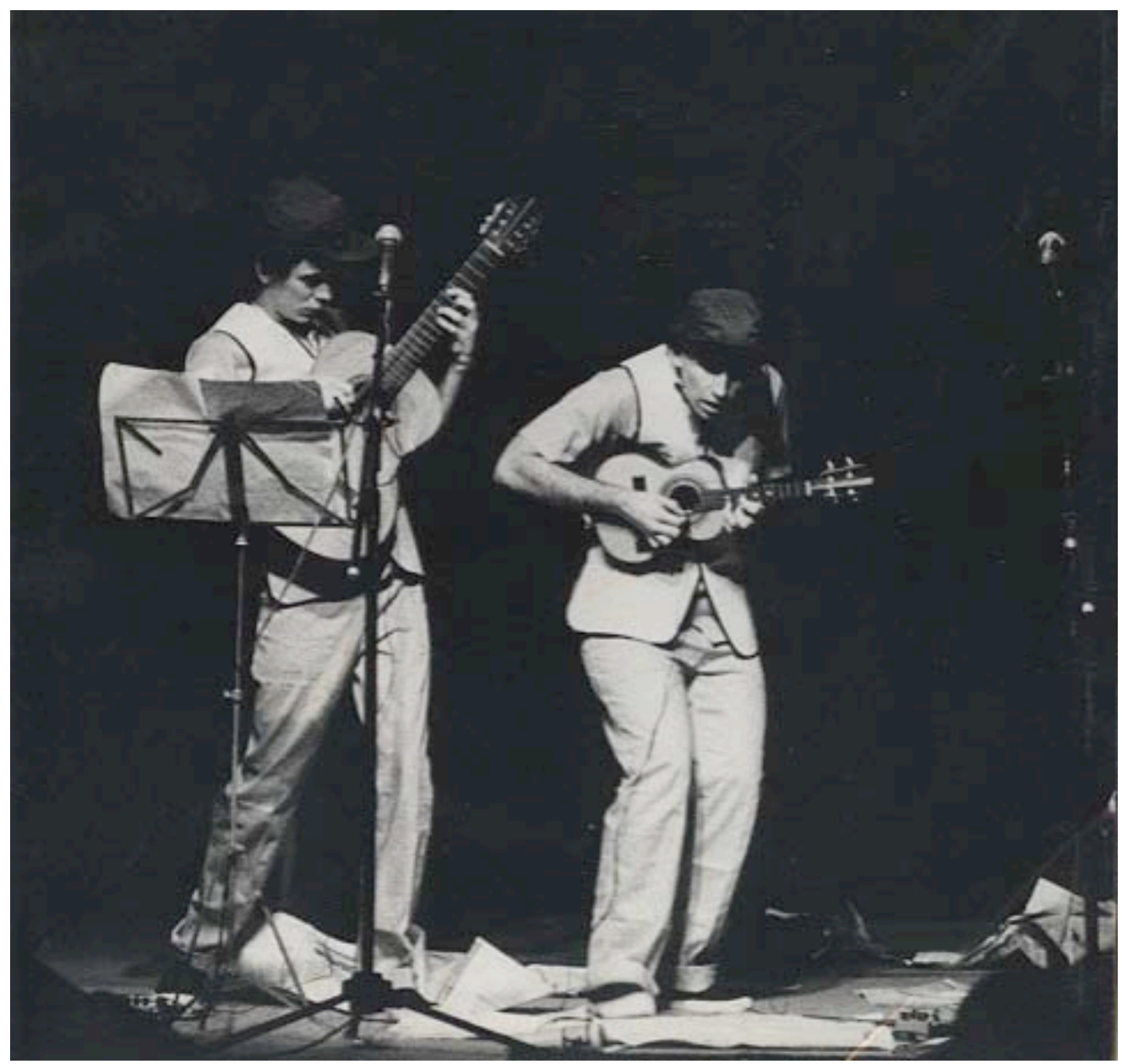

Figura 5 Dupla Especializada, Reflexões musicais, show-performance, 1986. Teatro de Bolso, Rio de Janeiro 


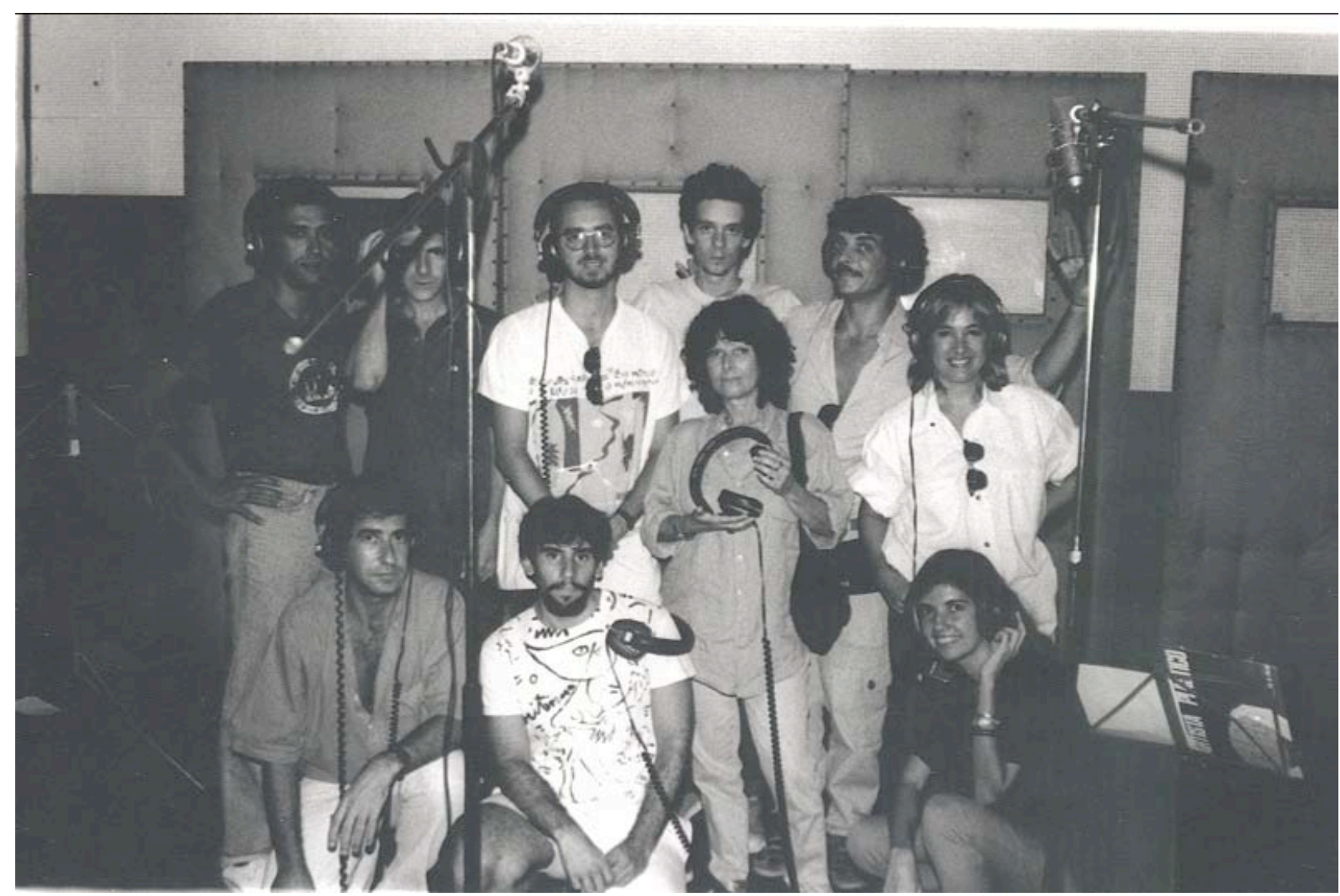

Figura 6 Dupla Especializada, Hino ao Dia Nacional do Artista-Plástico, 1987. Gravação, Estúdio Sonoviso, Rio de Janeiro.

Da esquerda para à direita, em pé: Paulo Roberto Leal, Antonio Manoel, Hilton Berredo, Ricardo Basbaum, Lygia Pape, Eneas Valle, Lucia Beatriz. Sentados: Gerardo Villaseca, Alexandre Dacosta, Márcia Ramos. 


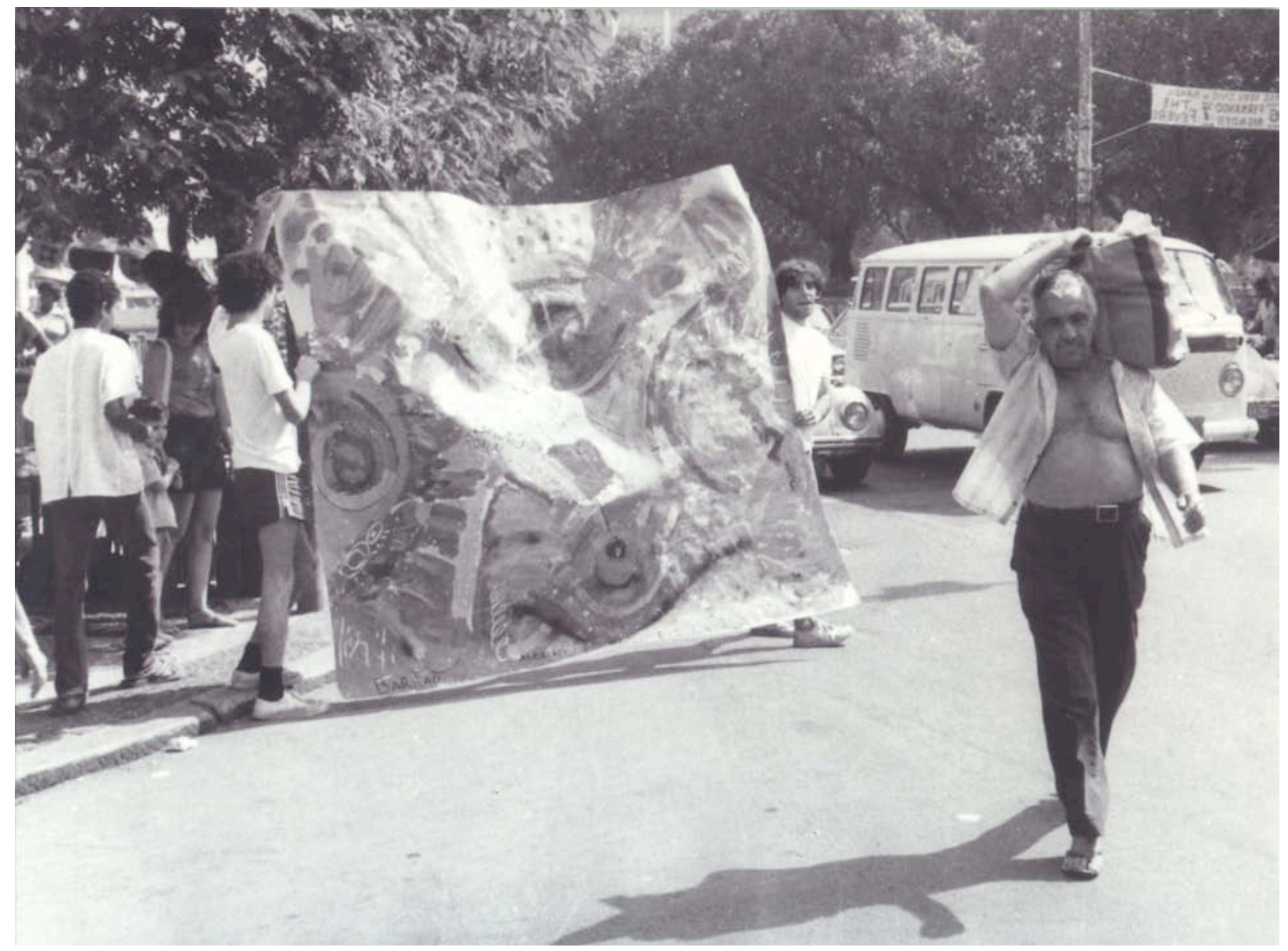

Figura 7 Seis Mãos, Improvisos de Pintura e Música, 1983, Ipanema, Rio de Janeiro. 


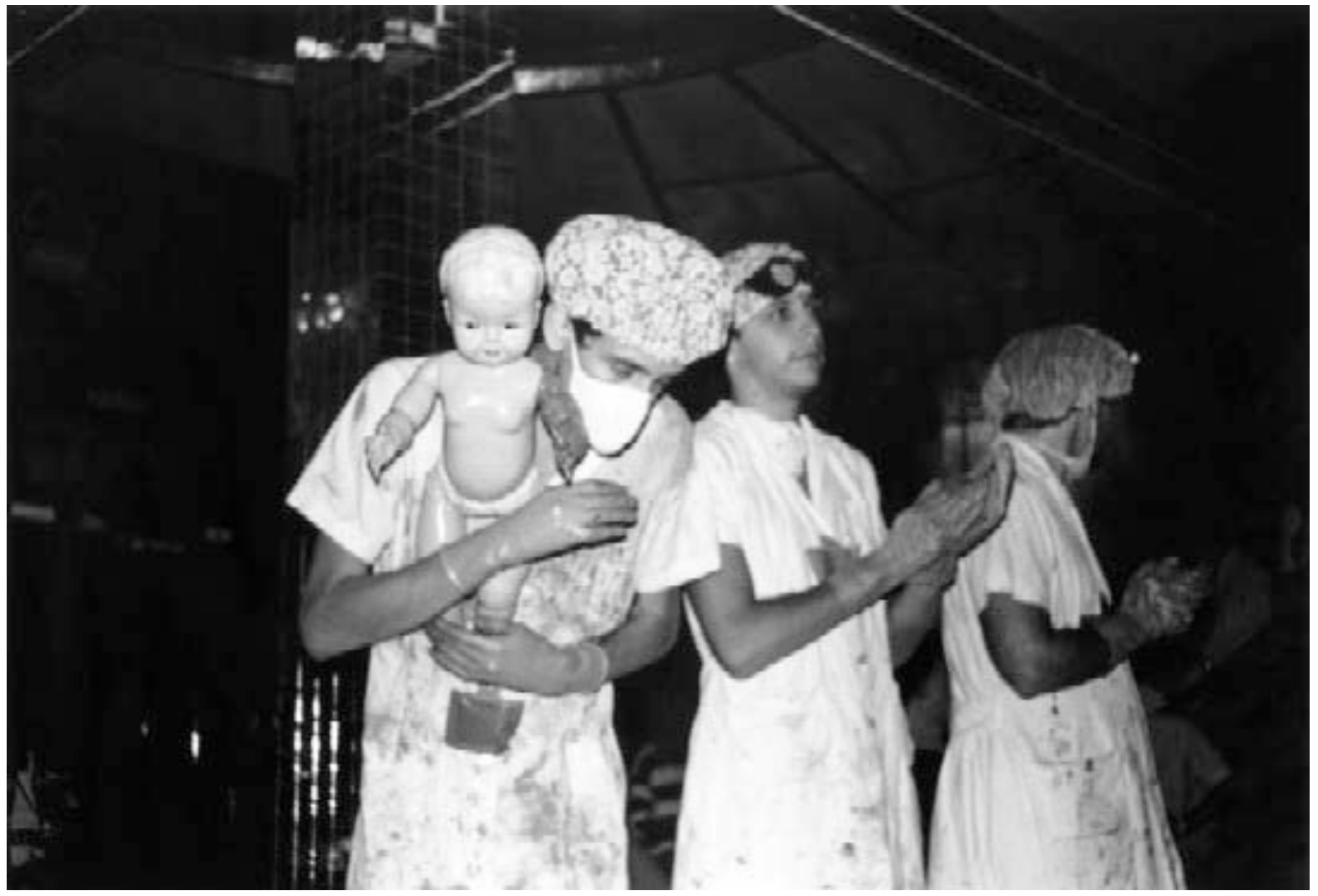

Figura 8 Seis Mãos, Calêndula Concreta: o incrível caso da menina loura que ficou com o braço mulato, 1987 , performance, vídeo, Bar Barão com Joana, Rio de Janeiro. 


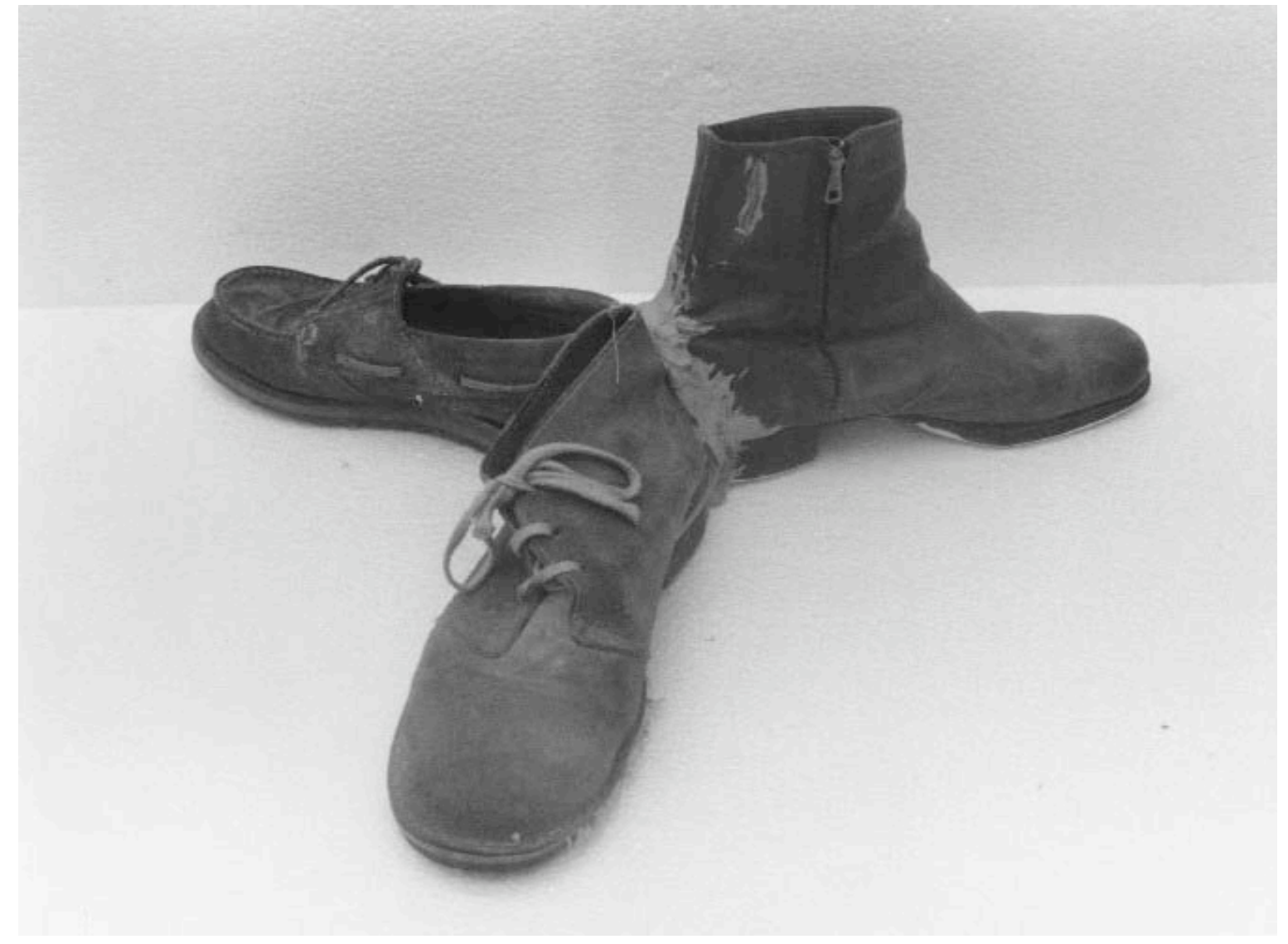

Figura 9 Seis Mãos, Sapatos Royal, 1991, objeto e performance. 


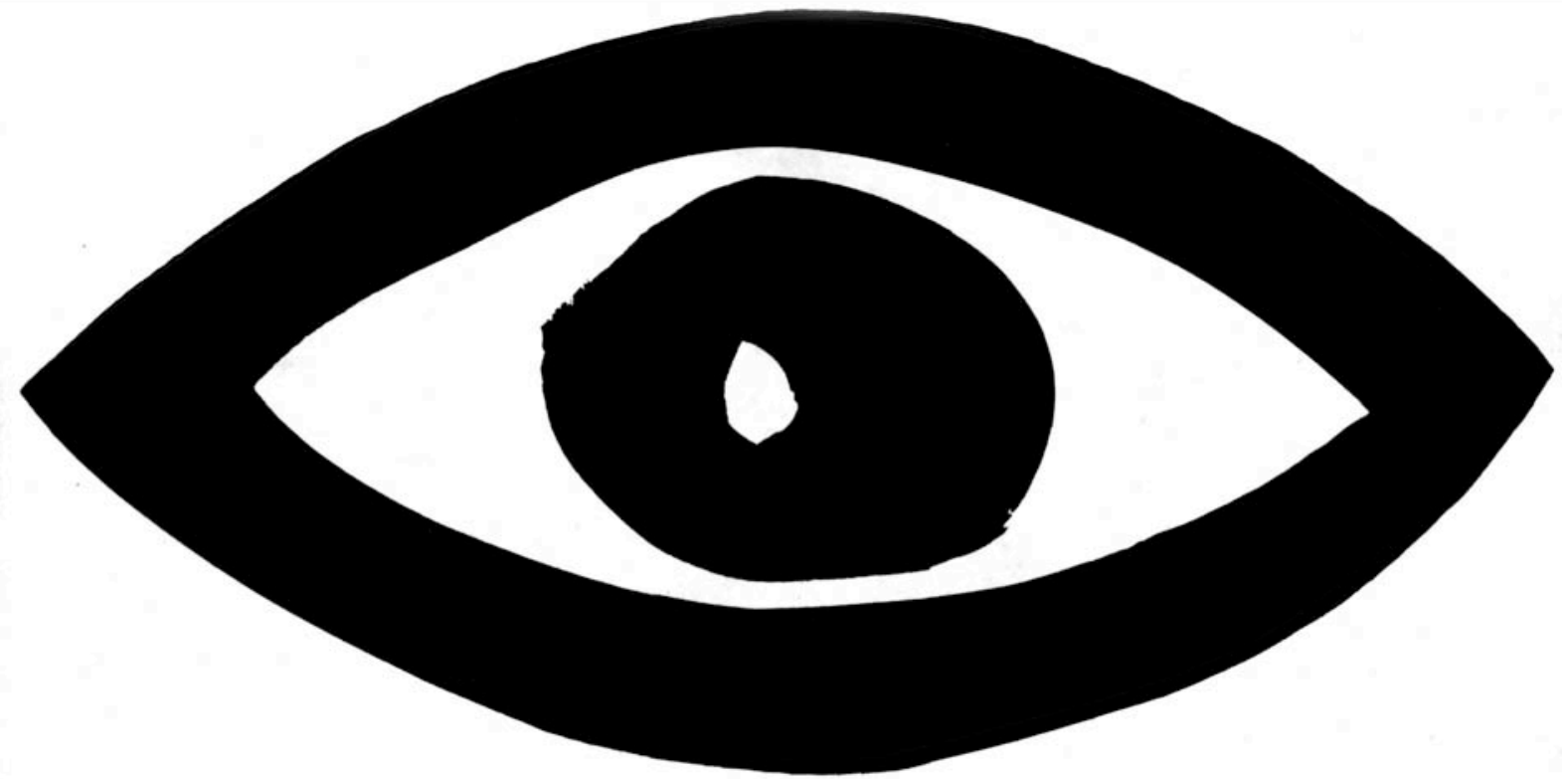

Figura 10 Ricardo Basbaum, Olho, adesivo, 1984, 19 x $9 \mathrm{~cm}$ 


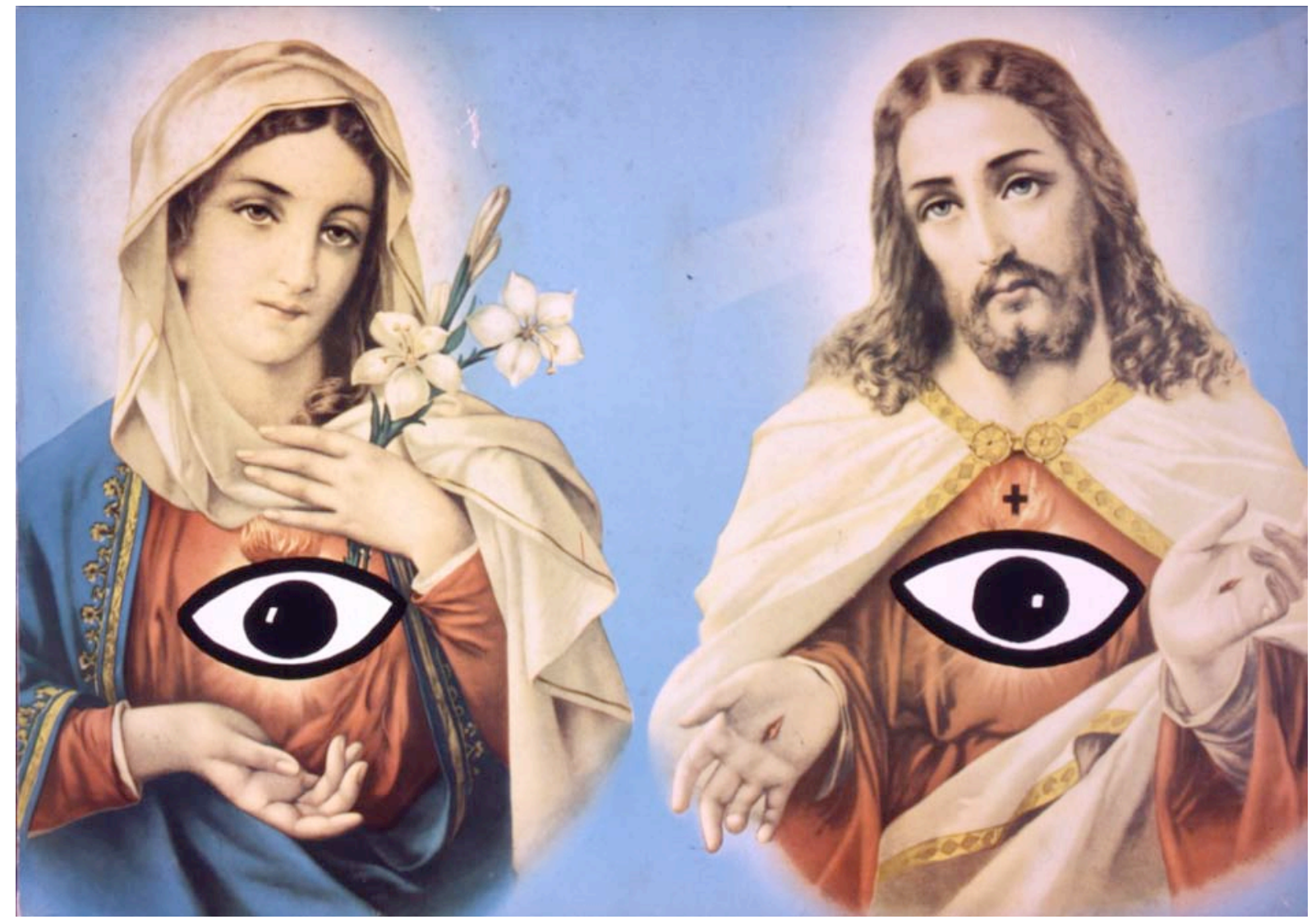

Figura 11 Ricardo Basbaum, Coração Sagrado, 1985, esmalte sintético, poster, 50 x $70 \mathrm{~cm}$ 


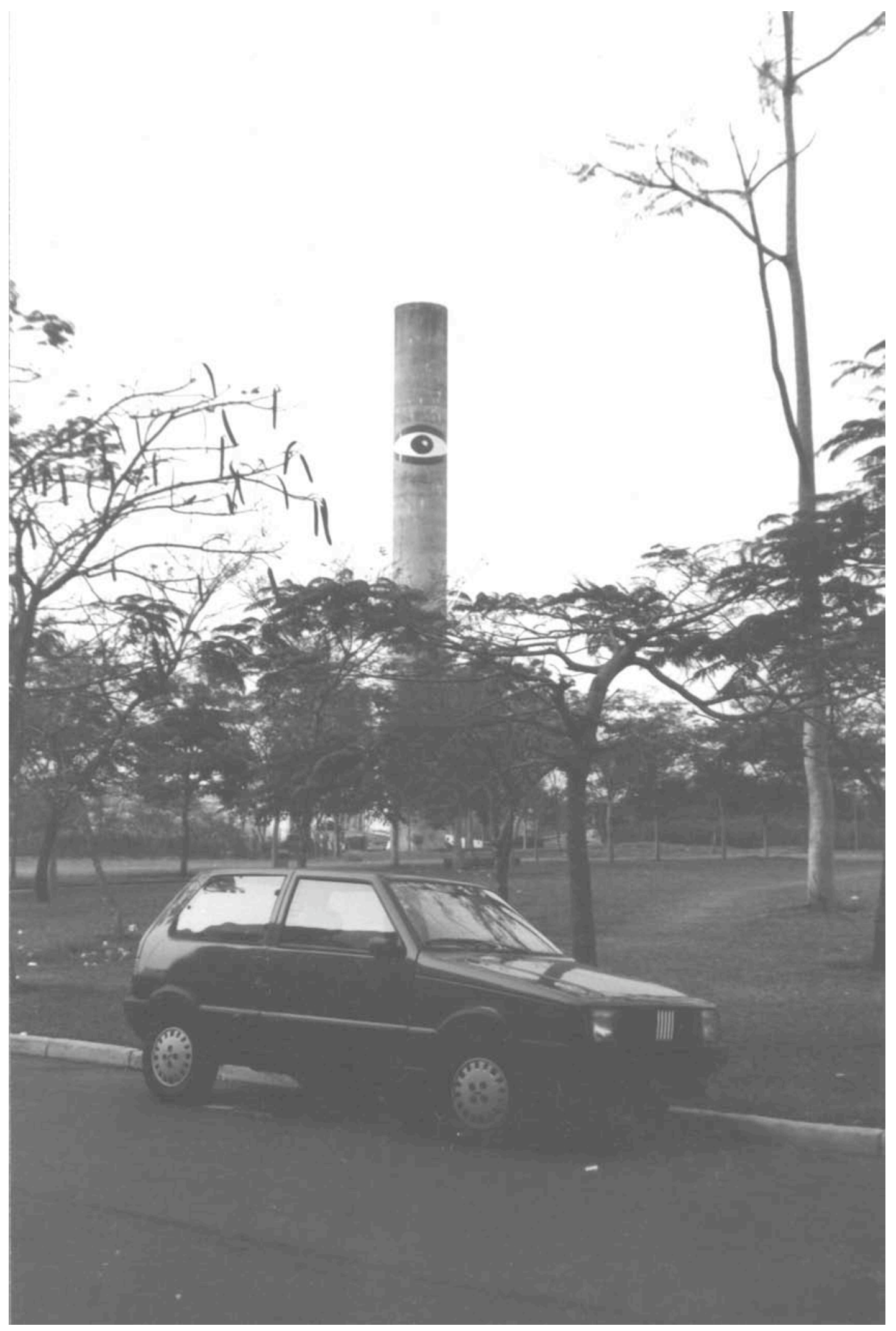

Figura 12 Ricardo Basbaum, Evento da Torre, 1987, Unicamp, Campinas. 


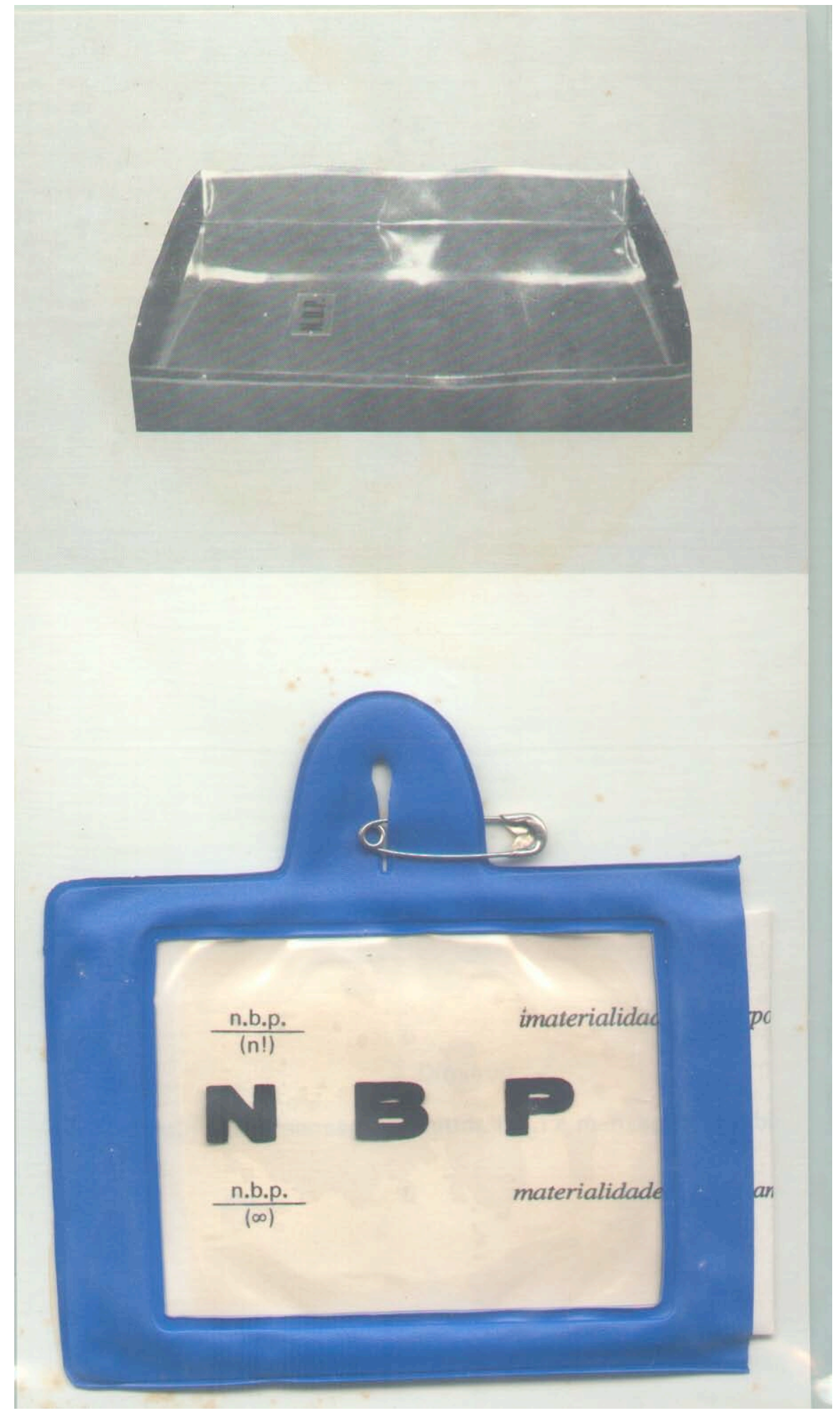

Figura 13 Ricardo Basbaum, Crachá (NBP), 1990 Múltiplo (frente) 
NOVAS BASES PARA A PERSONALIDADE

1. Use este crachá quando quiser.

2. Considere a relação cor do crachá/cor da roupa.

3. Considere o seu corpo como um veículo que permite o deslocamento de signos pelo ambiente.

(espacialização do pensamento)

4. Os olhares se fixarão'em N.B.P., não em você.

(despistamento)

5. Observe as alterações em seu comportamento.

6. $\mathbf{N}$ antes de $\mathbf{B}$ e $\mathbf{P}$.

7. Quando não quiser usar mais o crachá, retire-o.

8. N.B.P. já estará em você. (contaminação)

Ricardo Basbaum

Figura 14 Ricardo Basbaum, Crachá (NBP), 1990

Múltiplo (trás) 


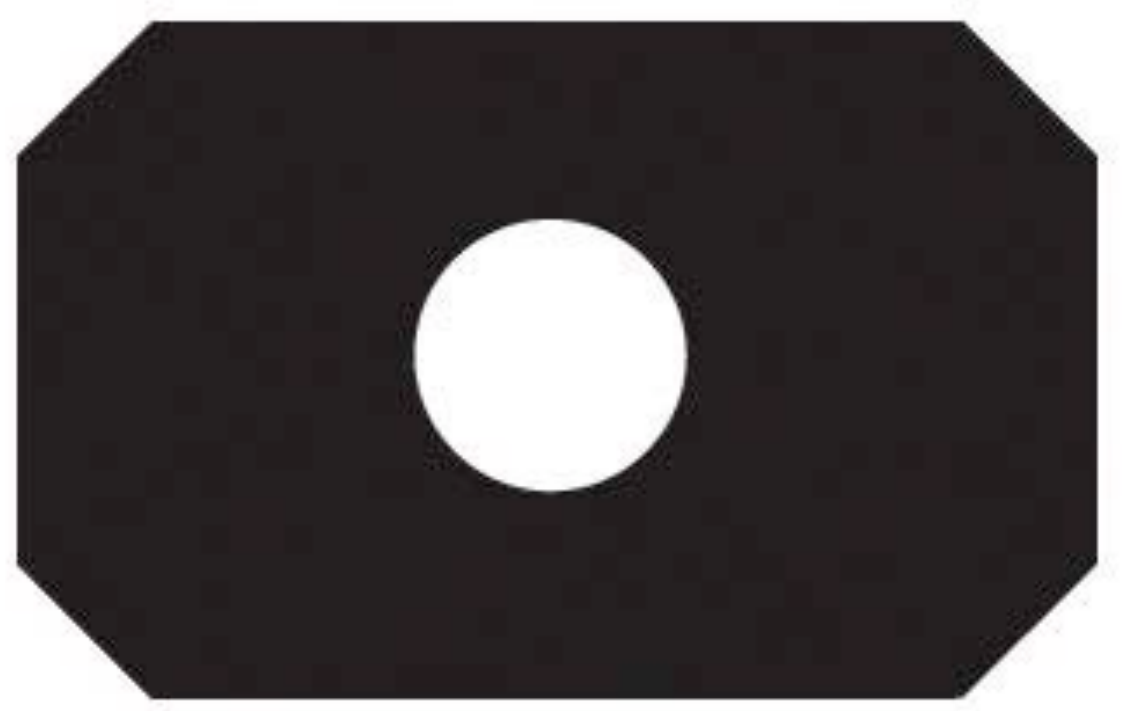

Figura 15 Ricardo Basbaum, forma especifica NBP, 1991 


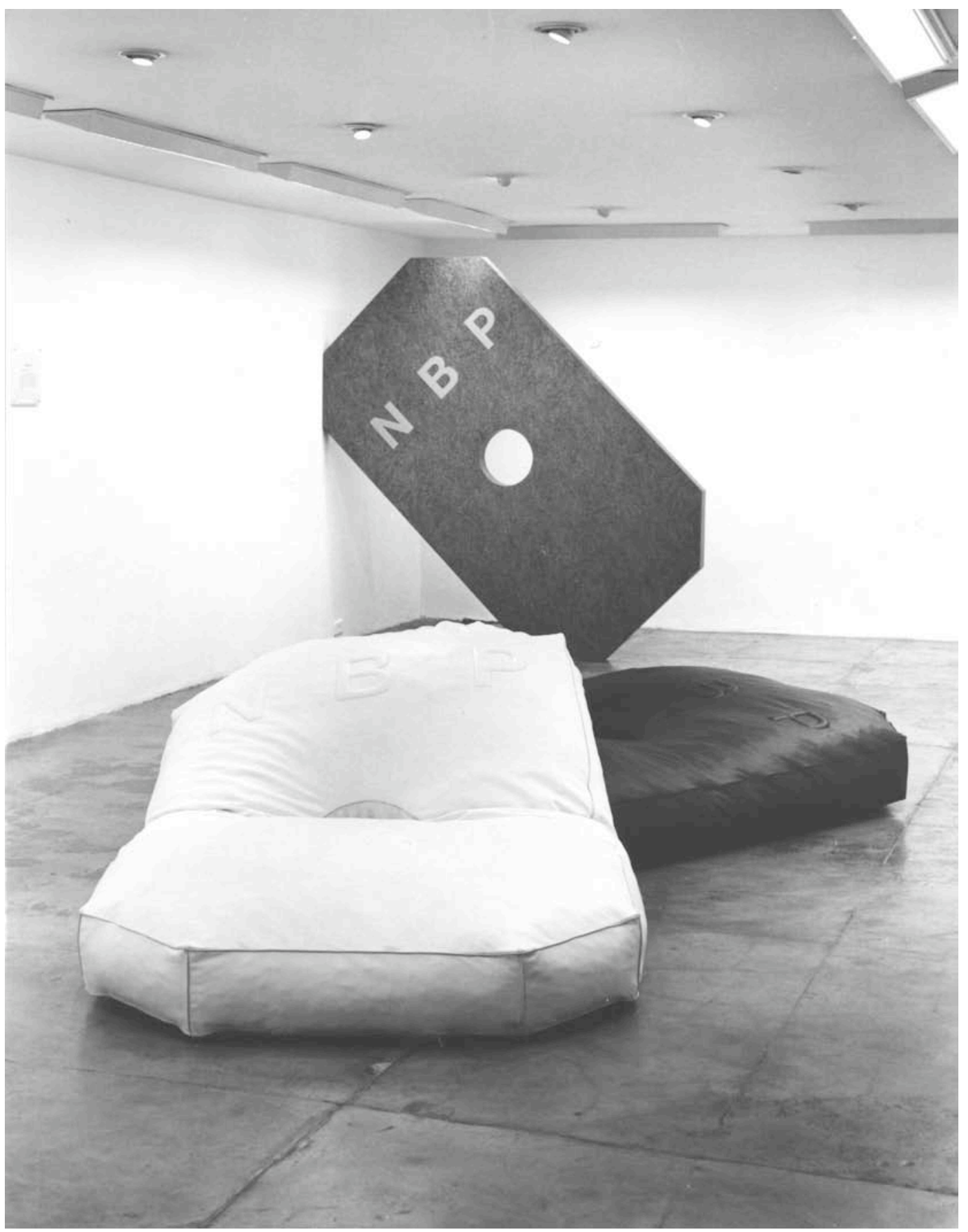

Figura 16 Ricardo Basbaum, NBP - Novas Bases para a Personalidade, 1993. Espaço Cultural Sergio Porto, Rio de Janeiro 


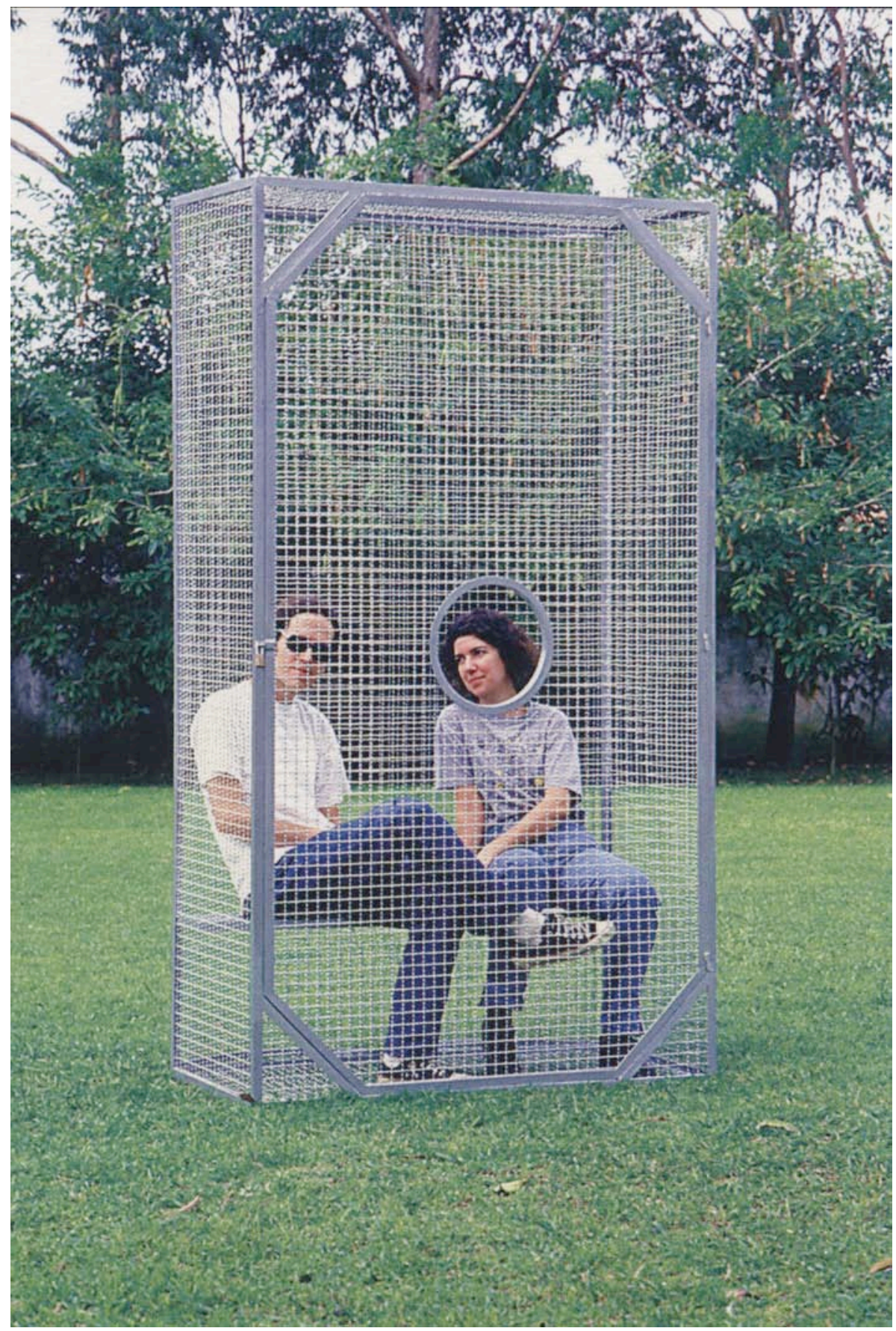

Figura 17 Ricardo Basbaum, NBP - Novas Bases para a Personalidade, 1993. ferro, tela de arame galvanizado, $228 \times 129 \times 80 \mathrm{~cm}$ 


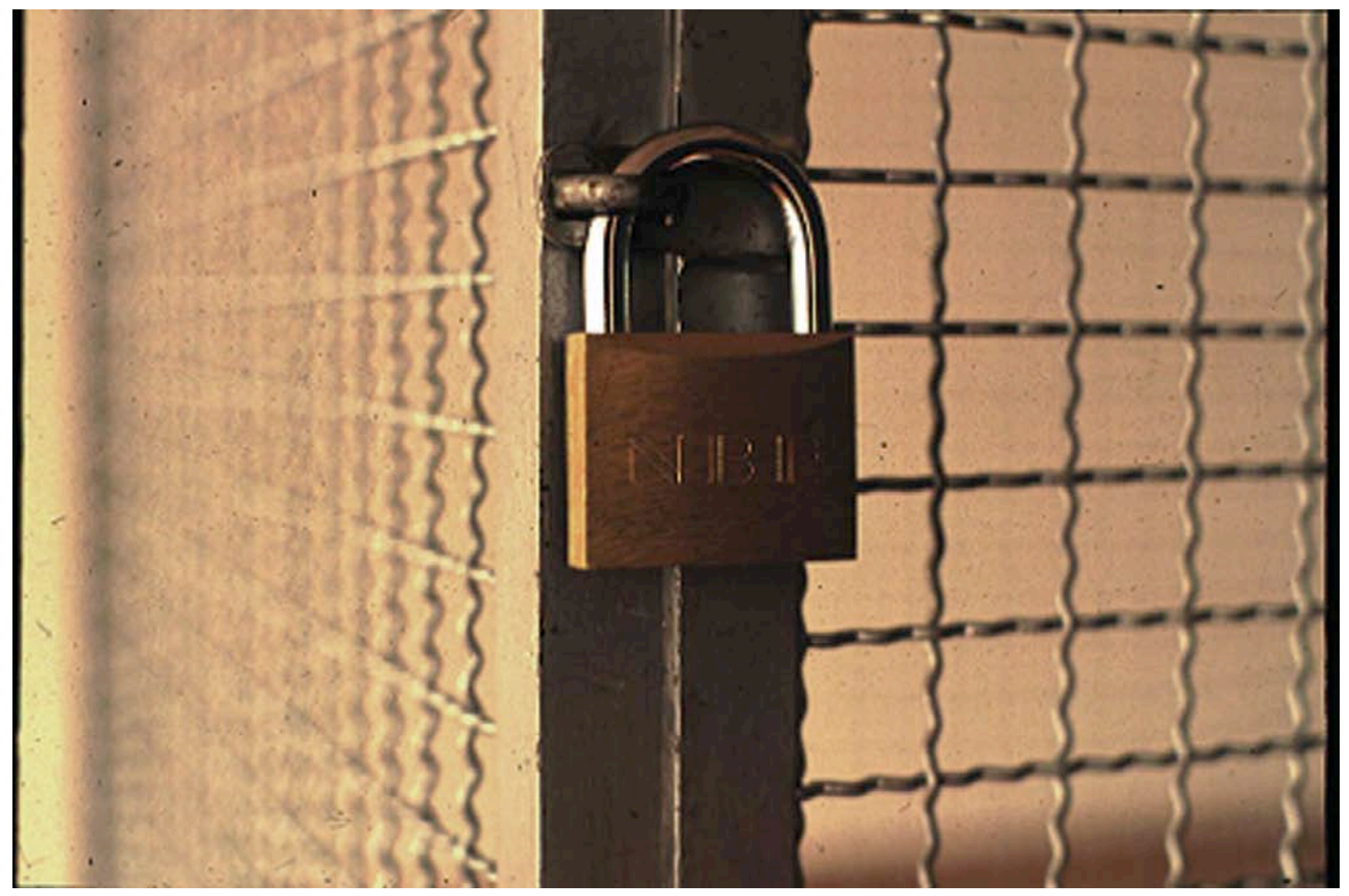

Figura 18 Ricardo Basbaum, NBP - Novas Bases para a Personalidade, 1993. ferro, tela de arame galvanizado, $228 \times 129 \times 80 \mathrm{~cm}$ (detalhe) 


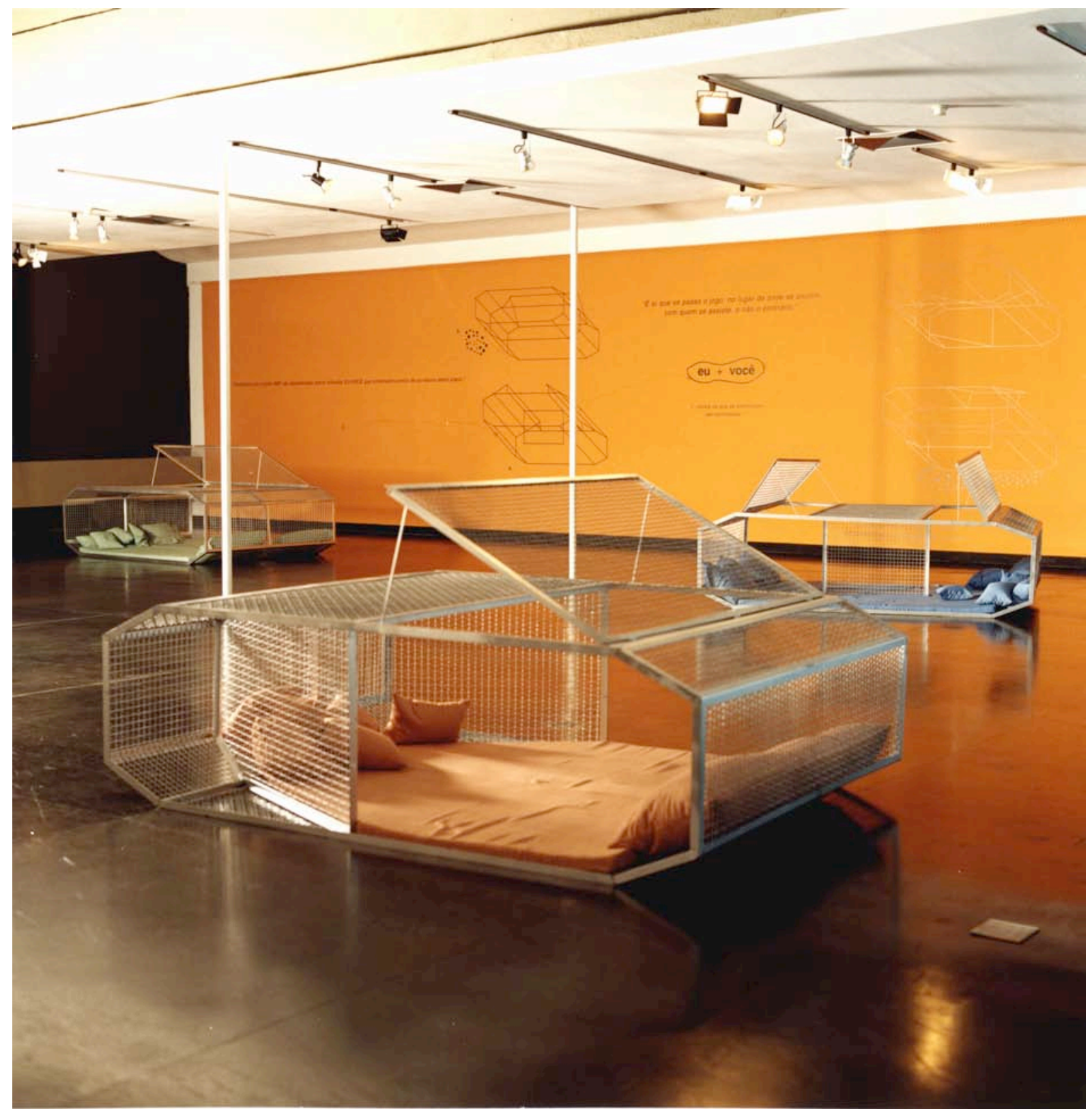

Figura 19 Ricardo Basbaum, cápsulas (NBP x eu-você), 2000 Museu de Arte Moderna do Rio de Janeiro 


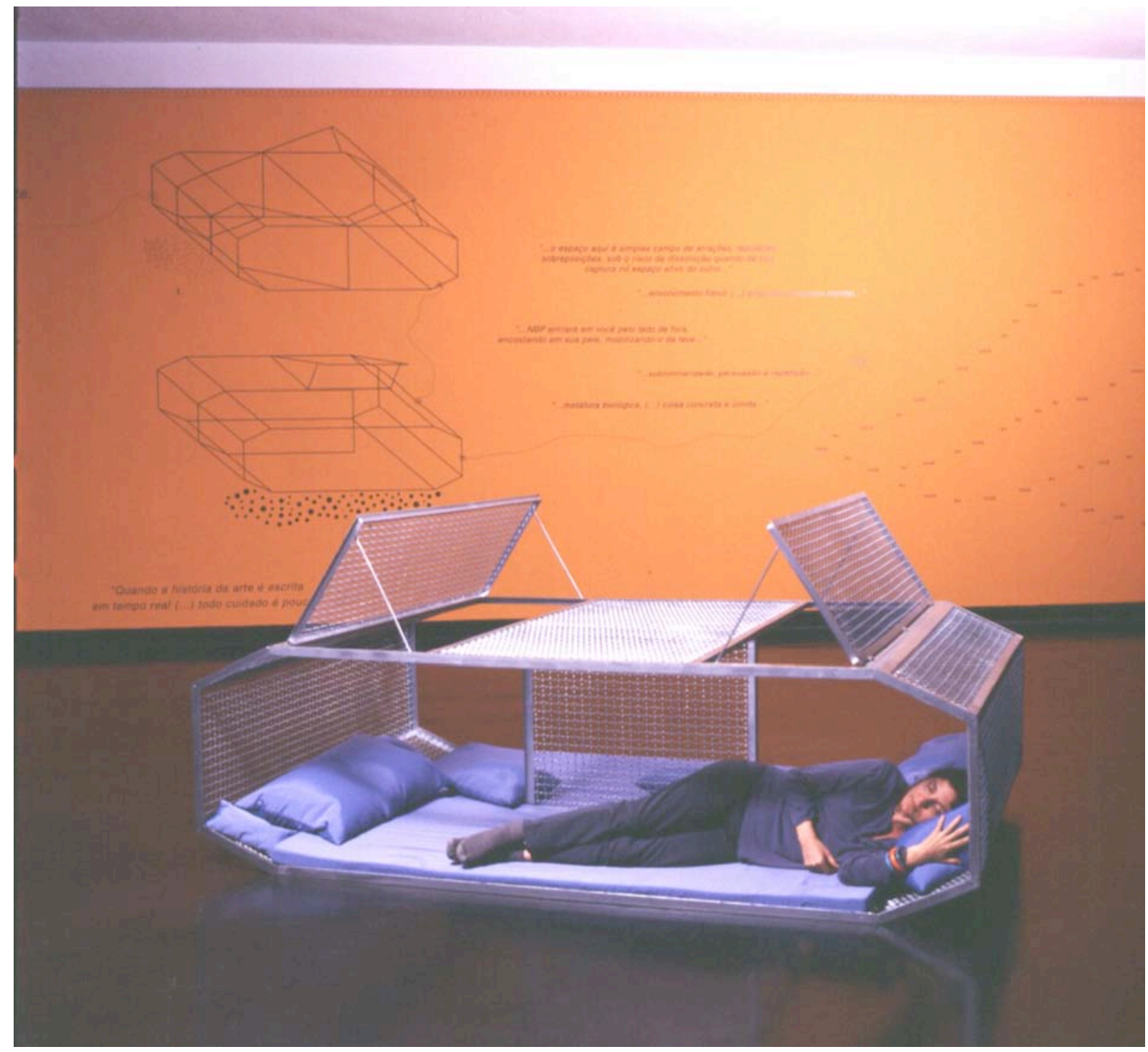

Figura 20 Ricardo Basbaum, cápsulas (NBP x eu-você), 2000 Museu de Arte Moderna, Rio de Janeiro 


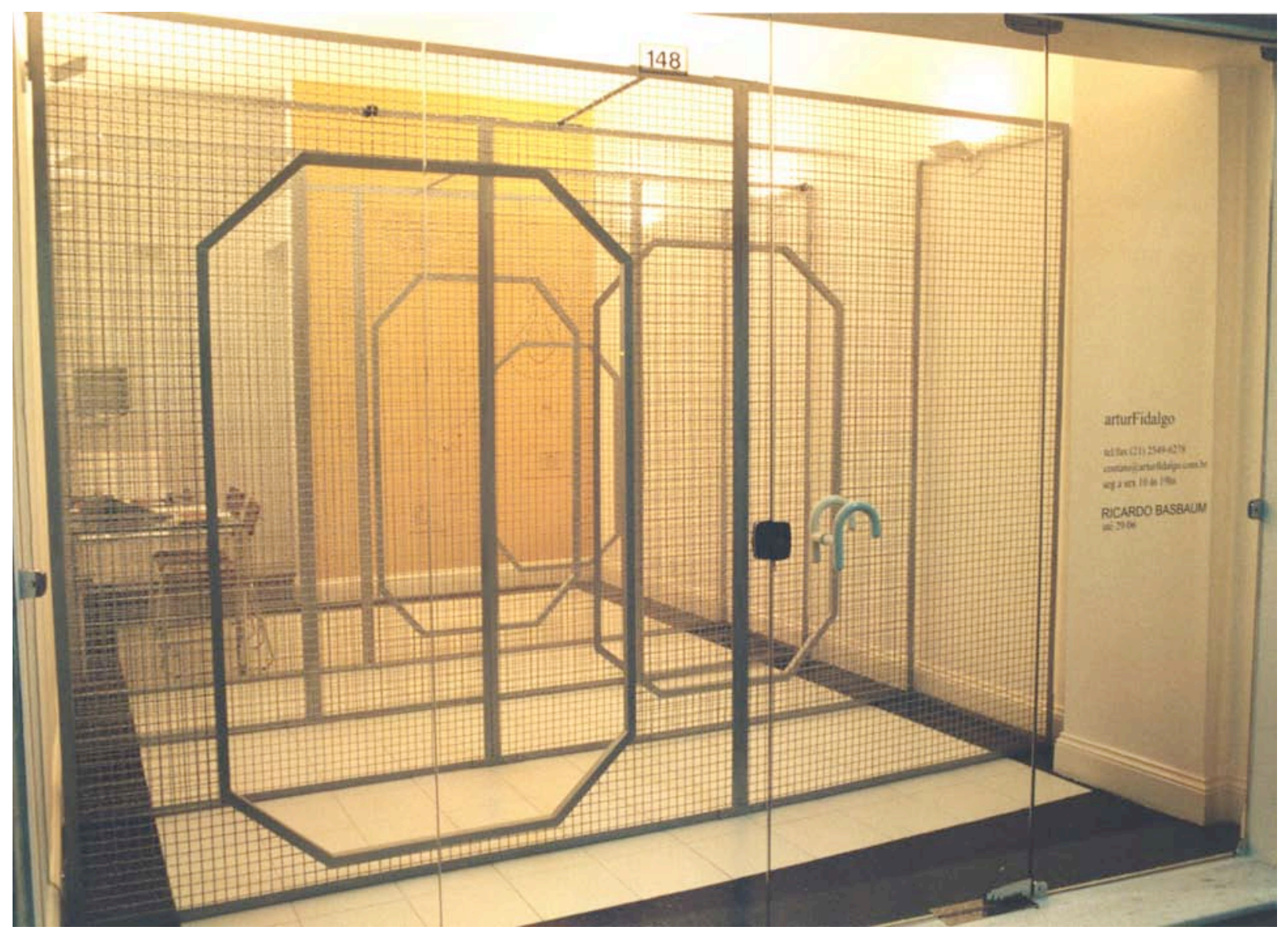

Figura 21 Ricardo Basbaum, passagens, 2001

Galeria Artur Fidalgo, Rio de Janeiro 


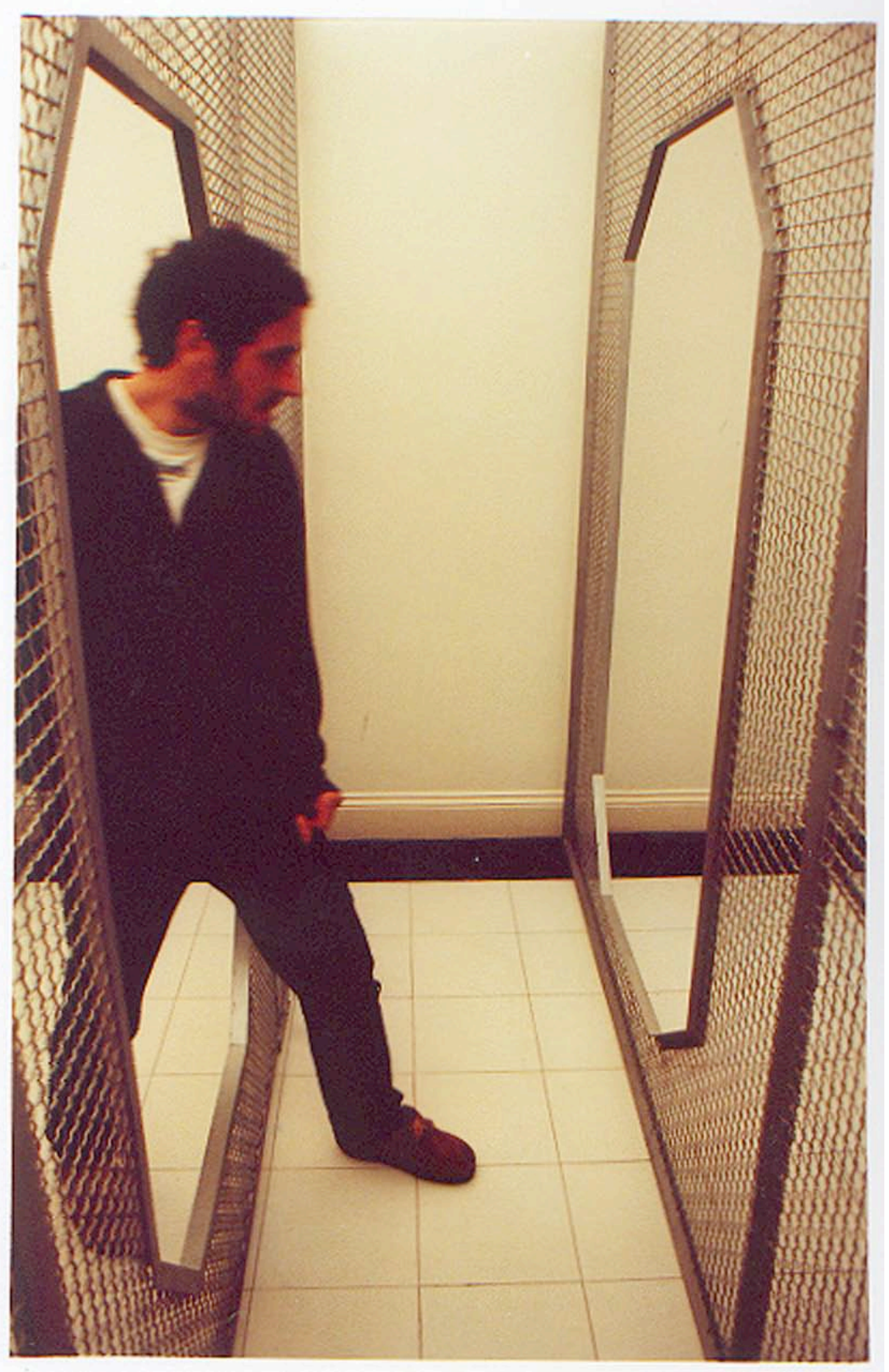

Figura 22 Ricardo Basbaum, passagens, 2001 Galeria Artur Fidalgo, Rio de Janeiro 


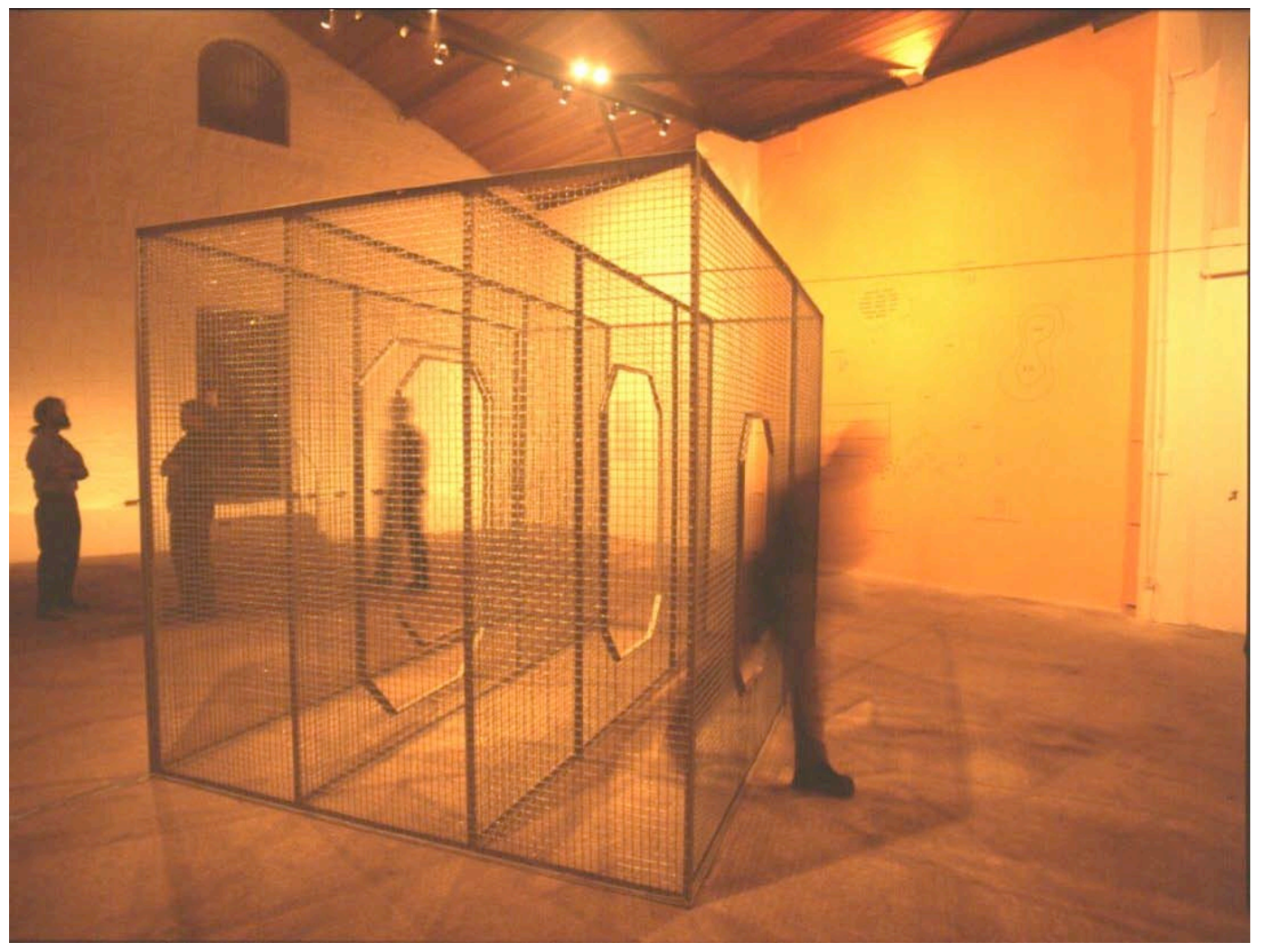

Figura 23 Ricardo Basbaum, passagens (NBP) 2, 2001 instalação no Museu Ferroviário da Vale do Rio Doce, Vitória 


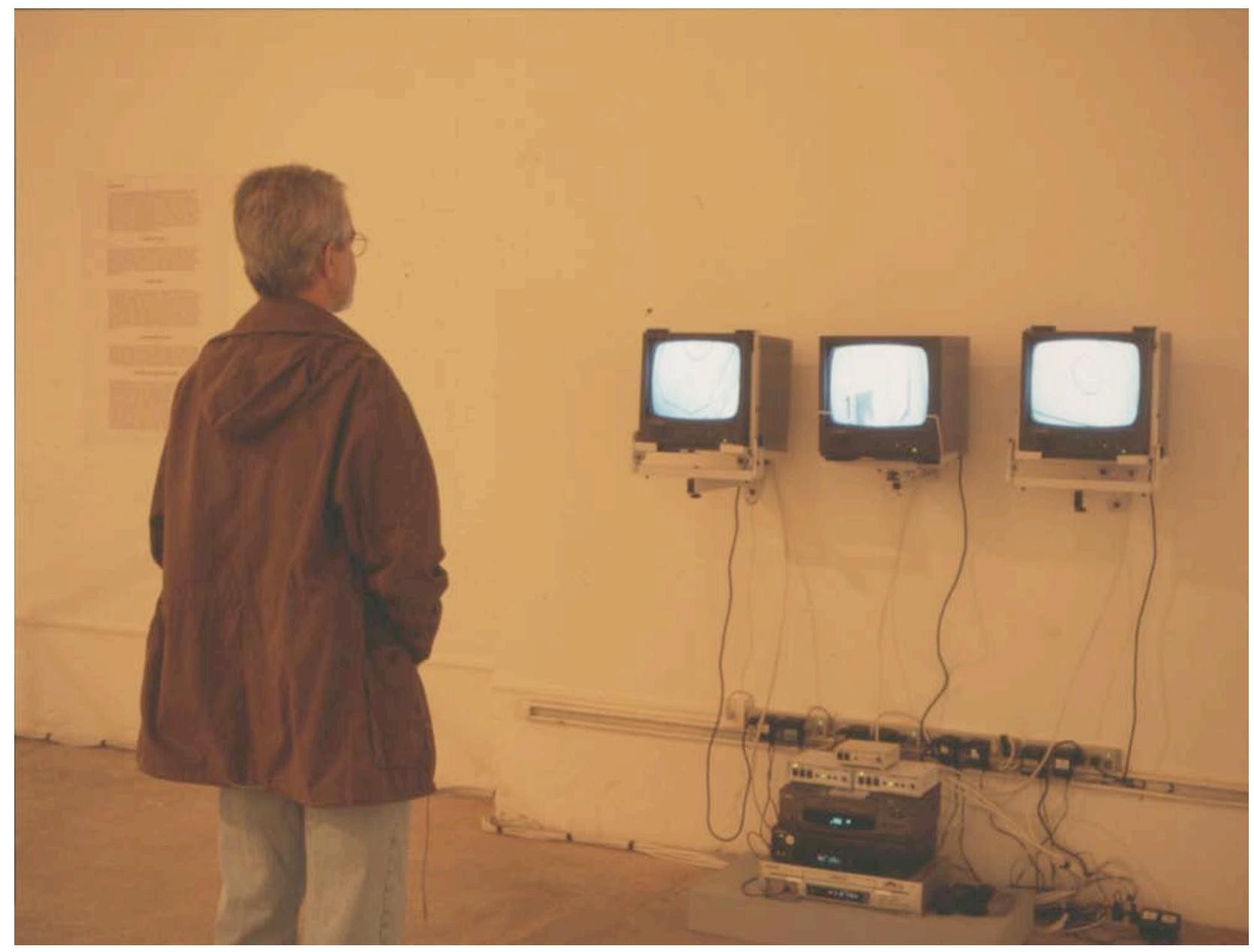

Figura 24 Ricardo Basbaum, sistema-cinema, 2001 instalação no Museu Ferroviário da Vale do Rio Doce, Vitória 


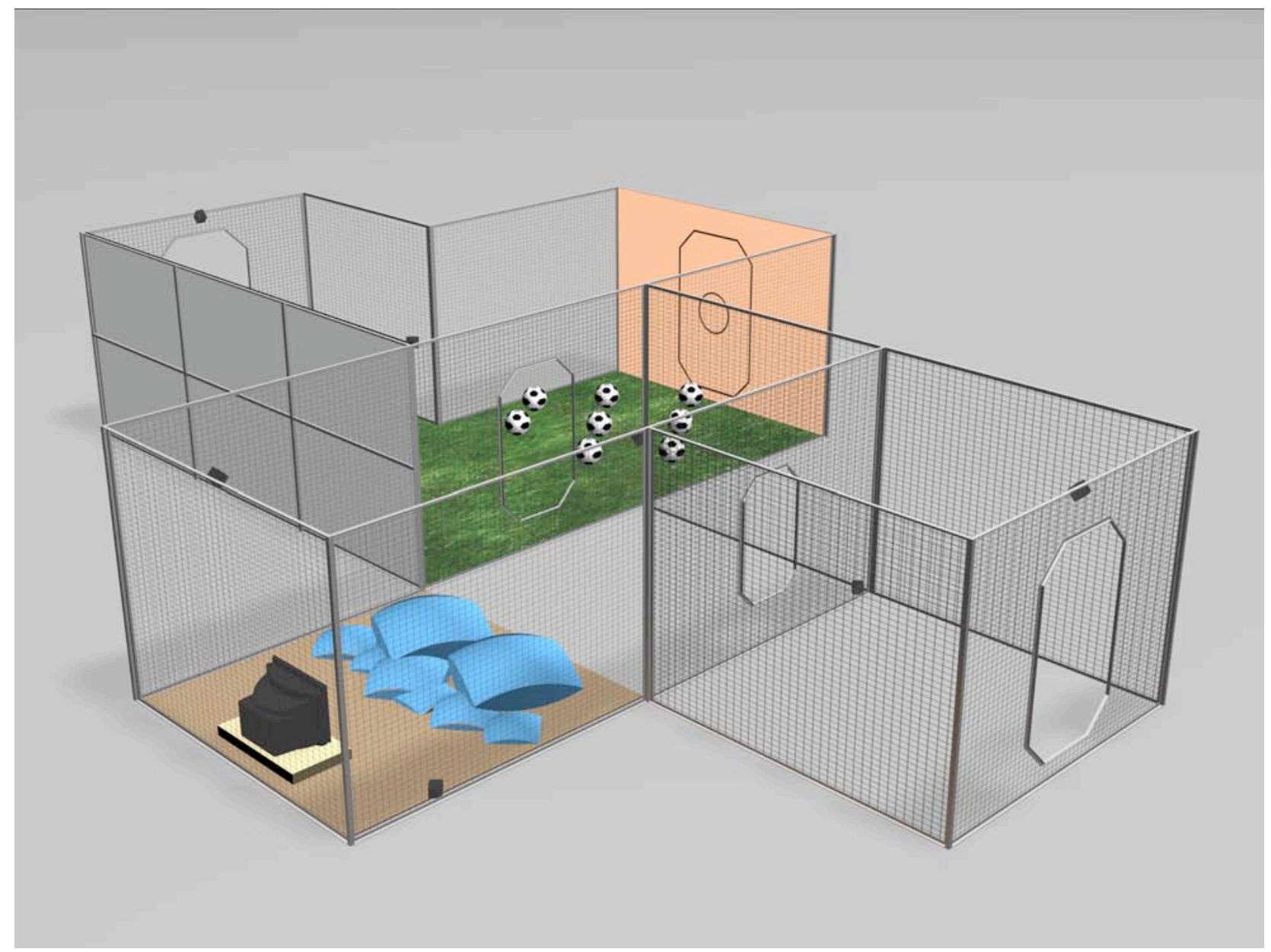

Figura 25 Ricardo Basbaum, transatravessamento, 2002

Projeto para a $25^{\mathrm{a}}$ Bienal Internacional de São Paulo 


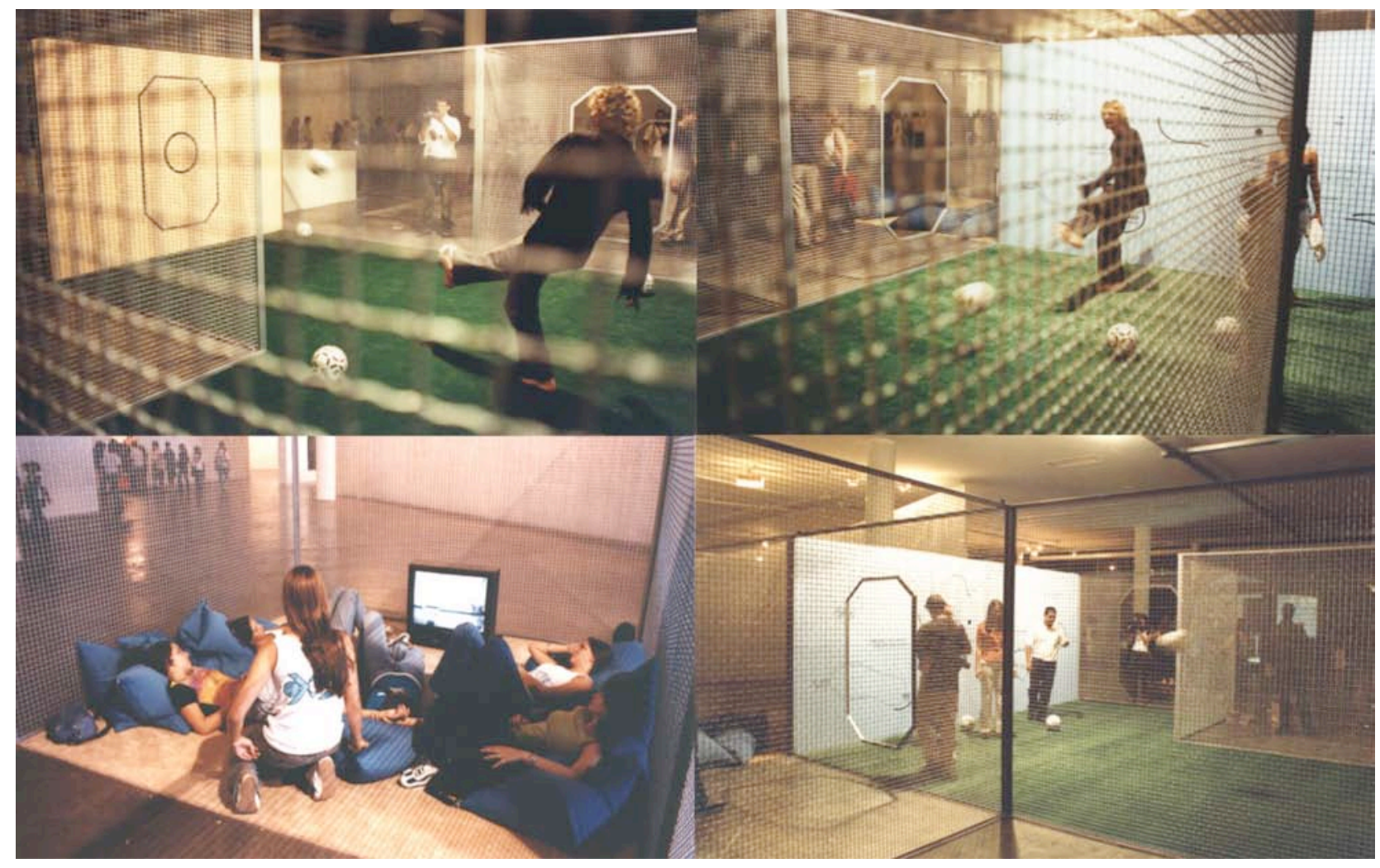

Figura 26 Ricardo Basbaum, transatravessamento, 2002 $25^{\mathrm{a}}$ Bienal Internacional de São Paulo 


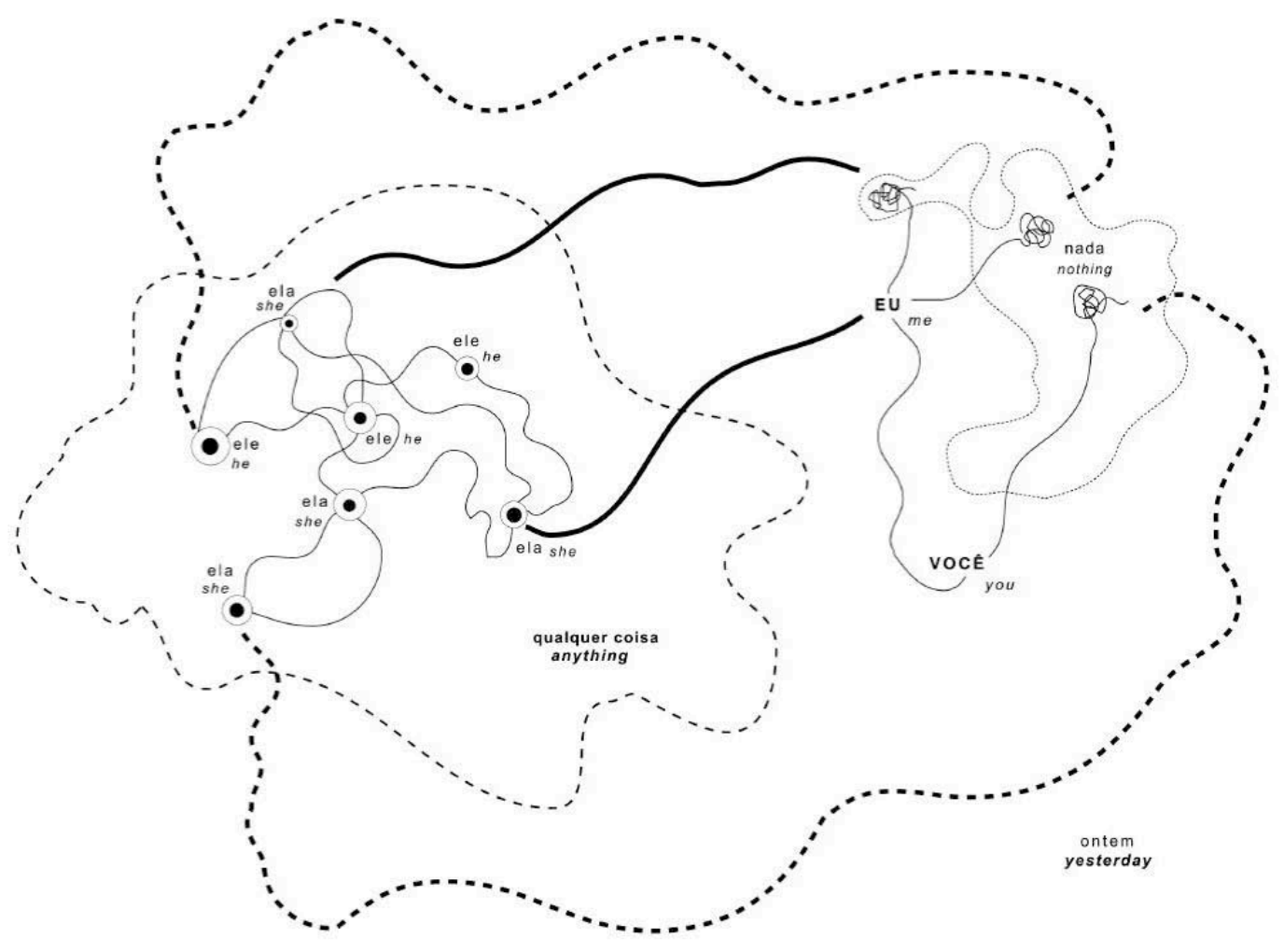

Figura 27 Ricardo Basbaum, diagrama (série love songs), 2000 


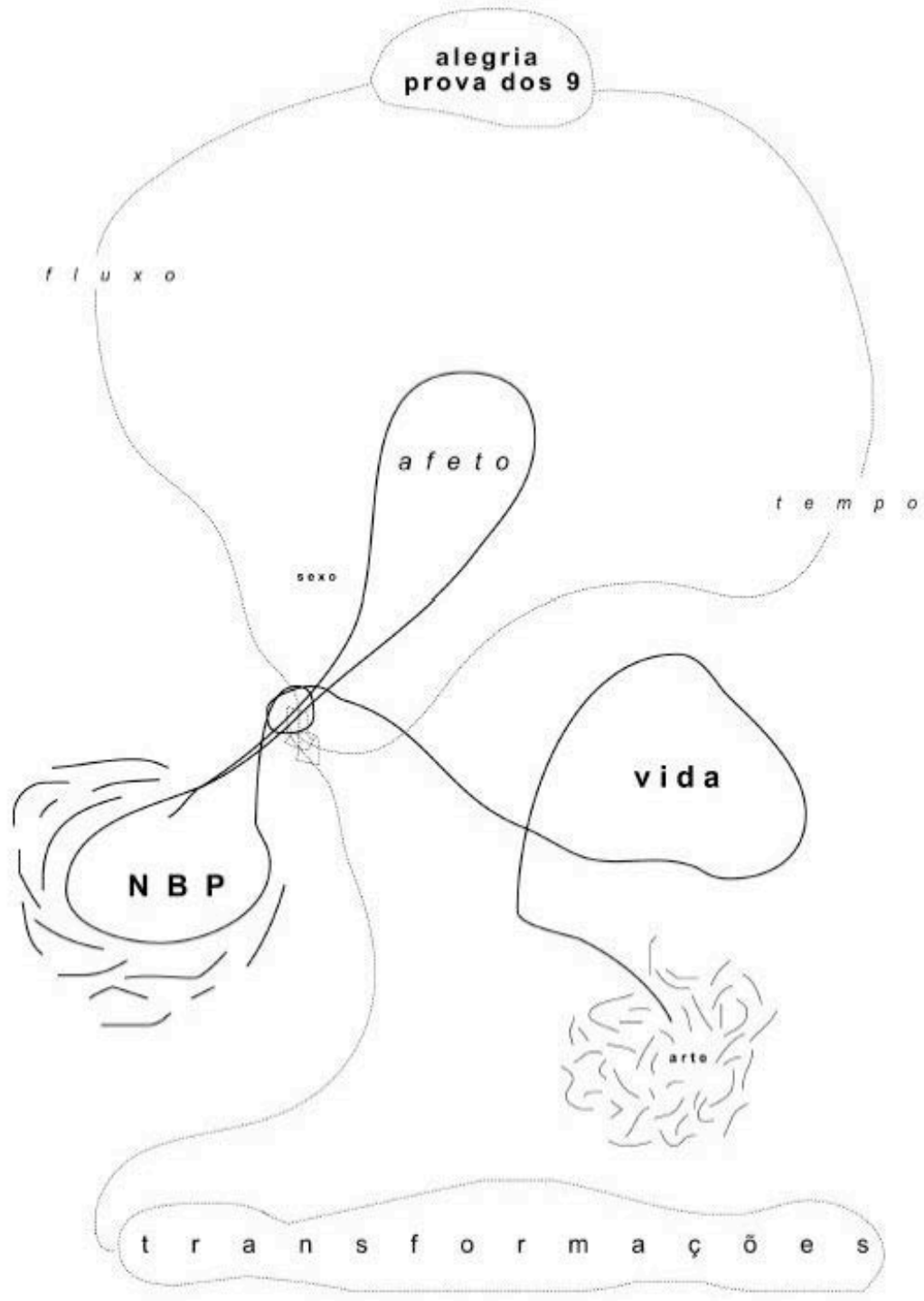

AMOR ?

Figura 28 Ricardo Basbaum, diagrama (série love songs), 1994 


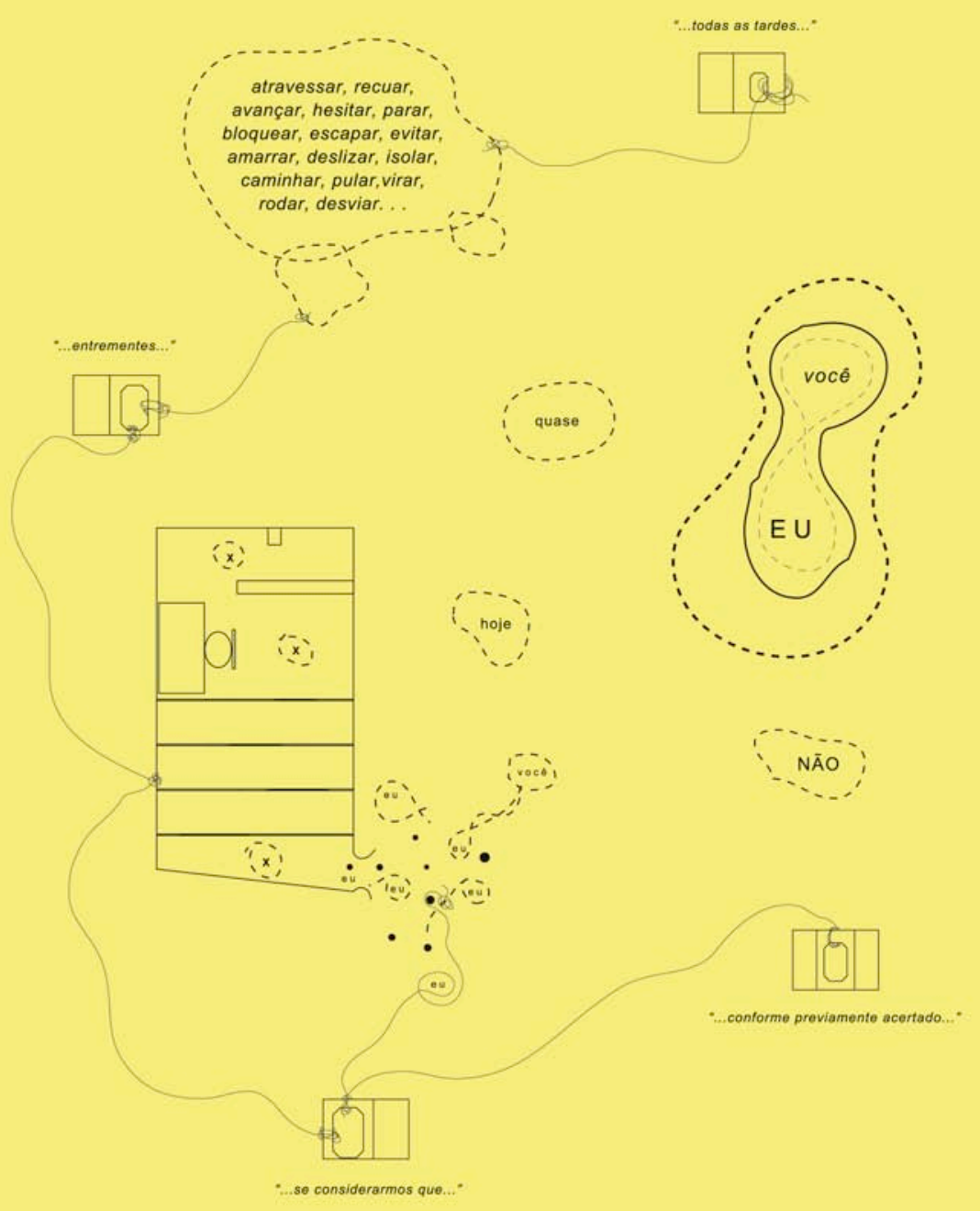

Figura 29 Ricardo Basbaum, diagrama (passagens), 2001 


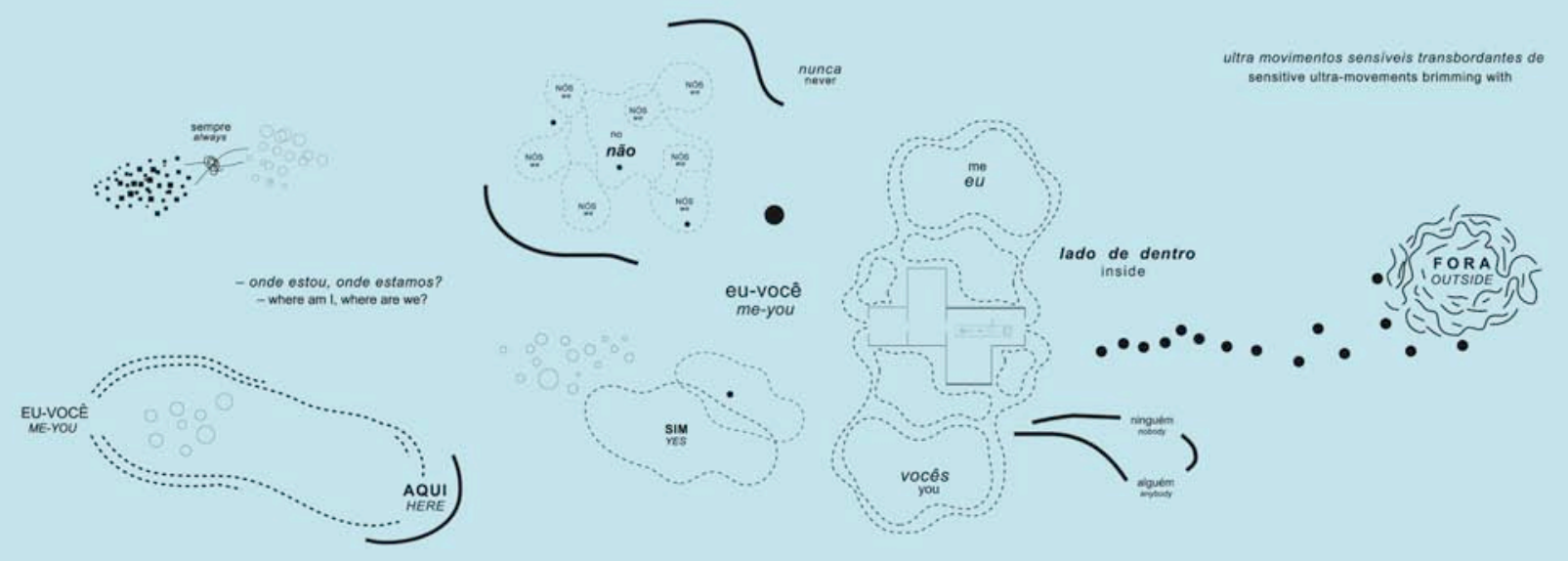

Figura 30 Ricardo Basbaum, diagrama (transatravessamento), 2002 


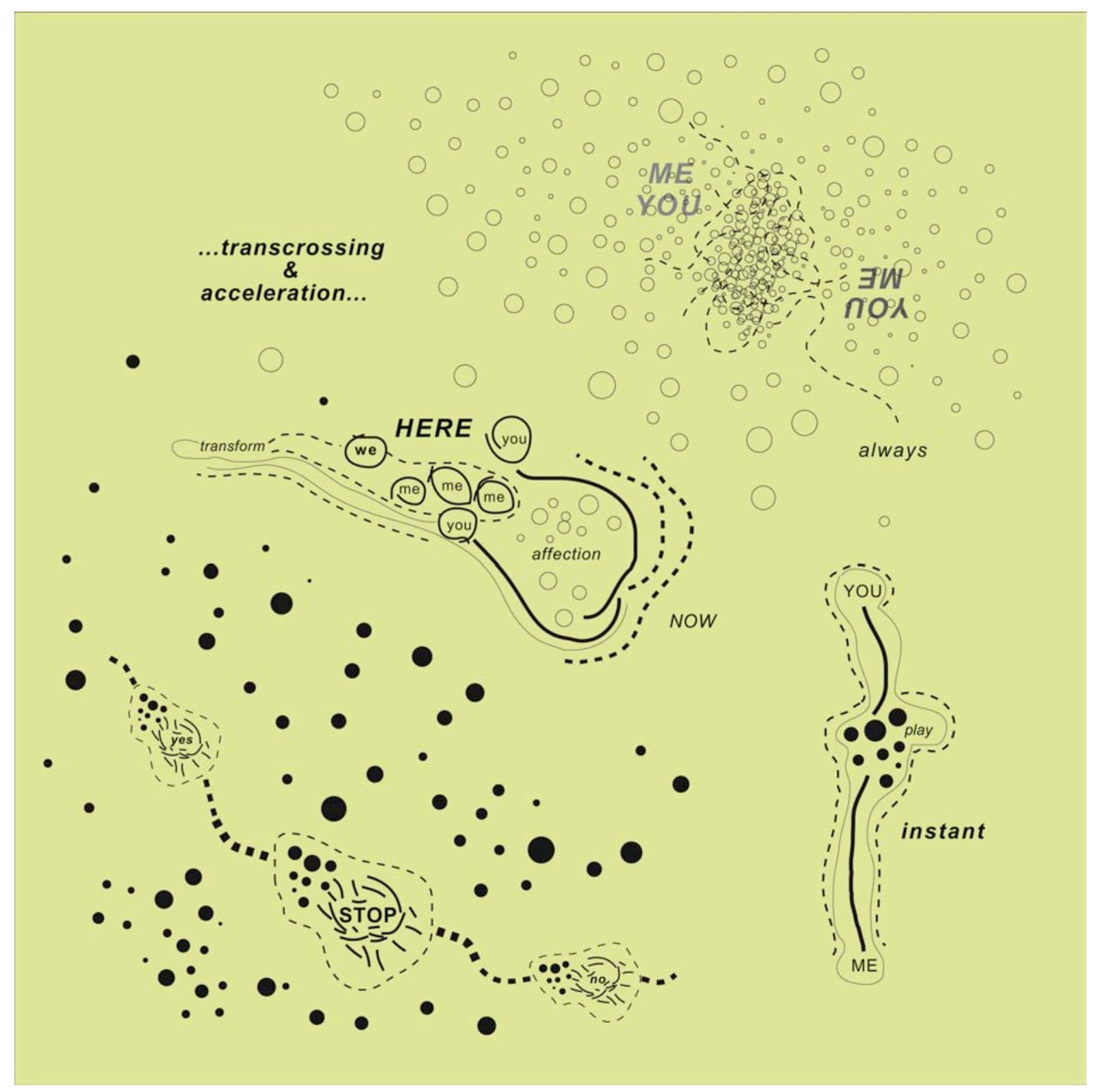

Figura 31 Ricardo Basbaum, diagram (me-you series), 2002 


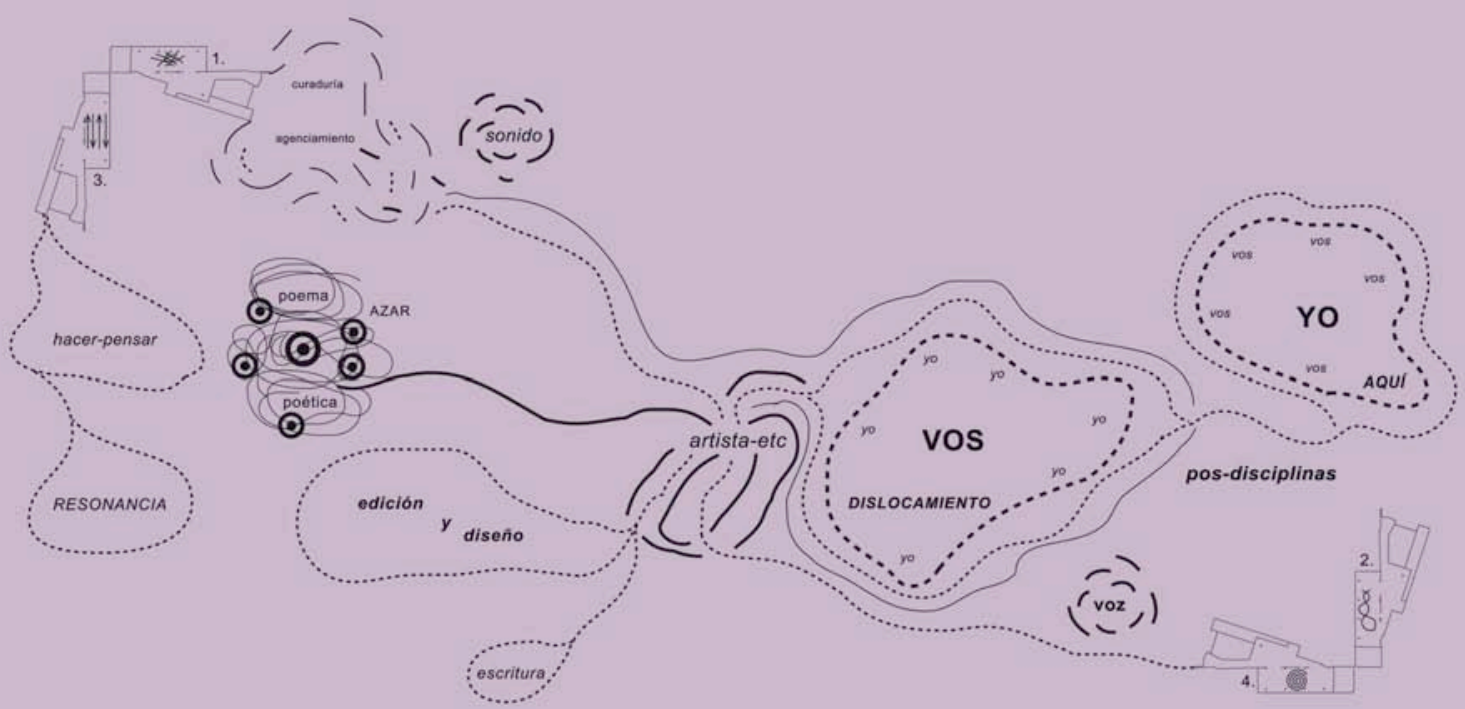

Figura 32 Ricardo Basbaum, diagrama (artista-etc), 2004 


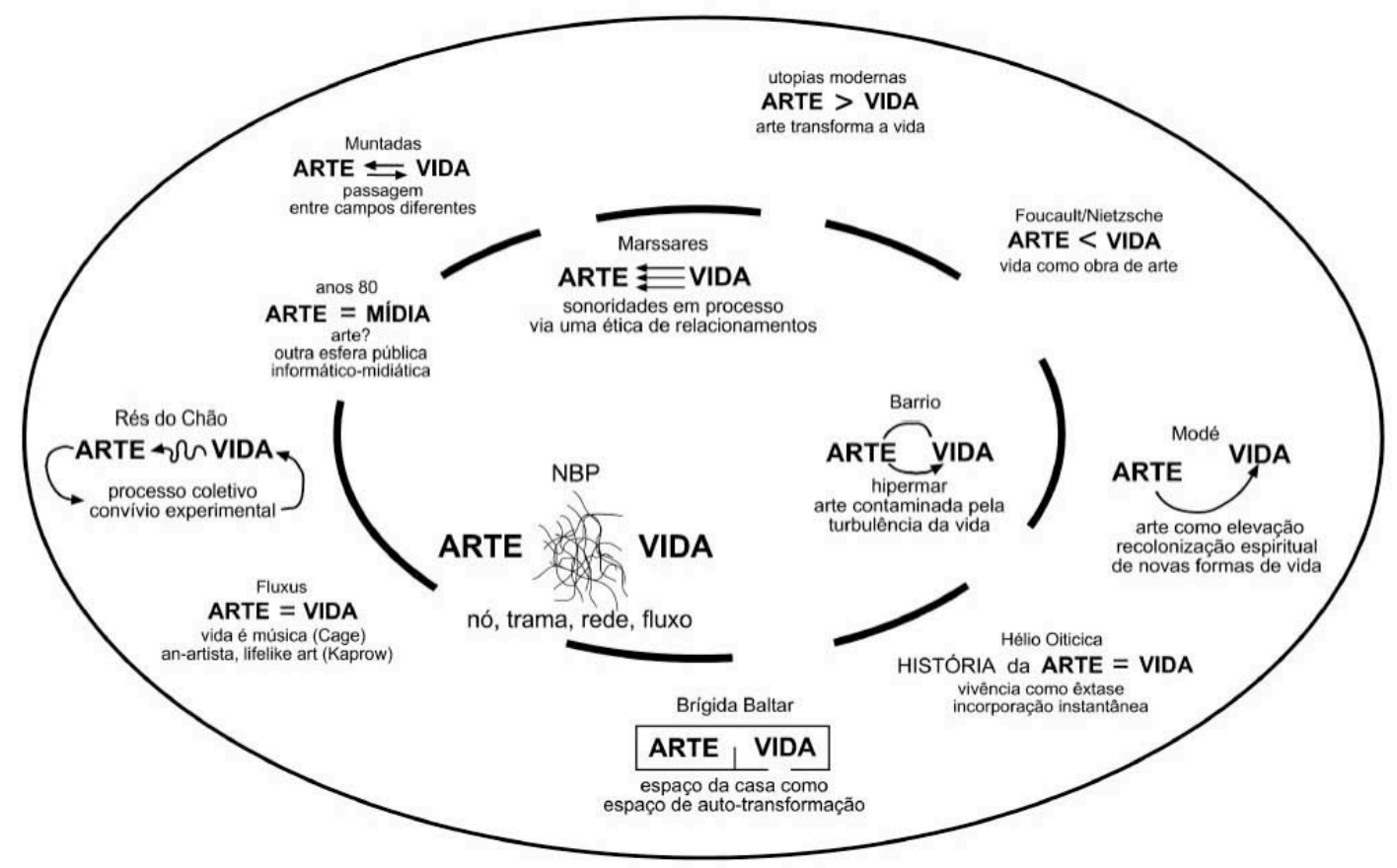

Figura 33 Ricardo Basbaum, diagrama (arte-vida), 2000-2003 


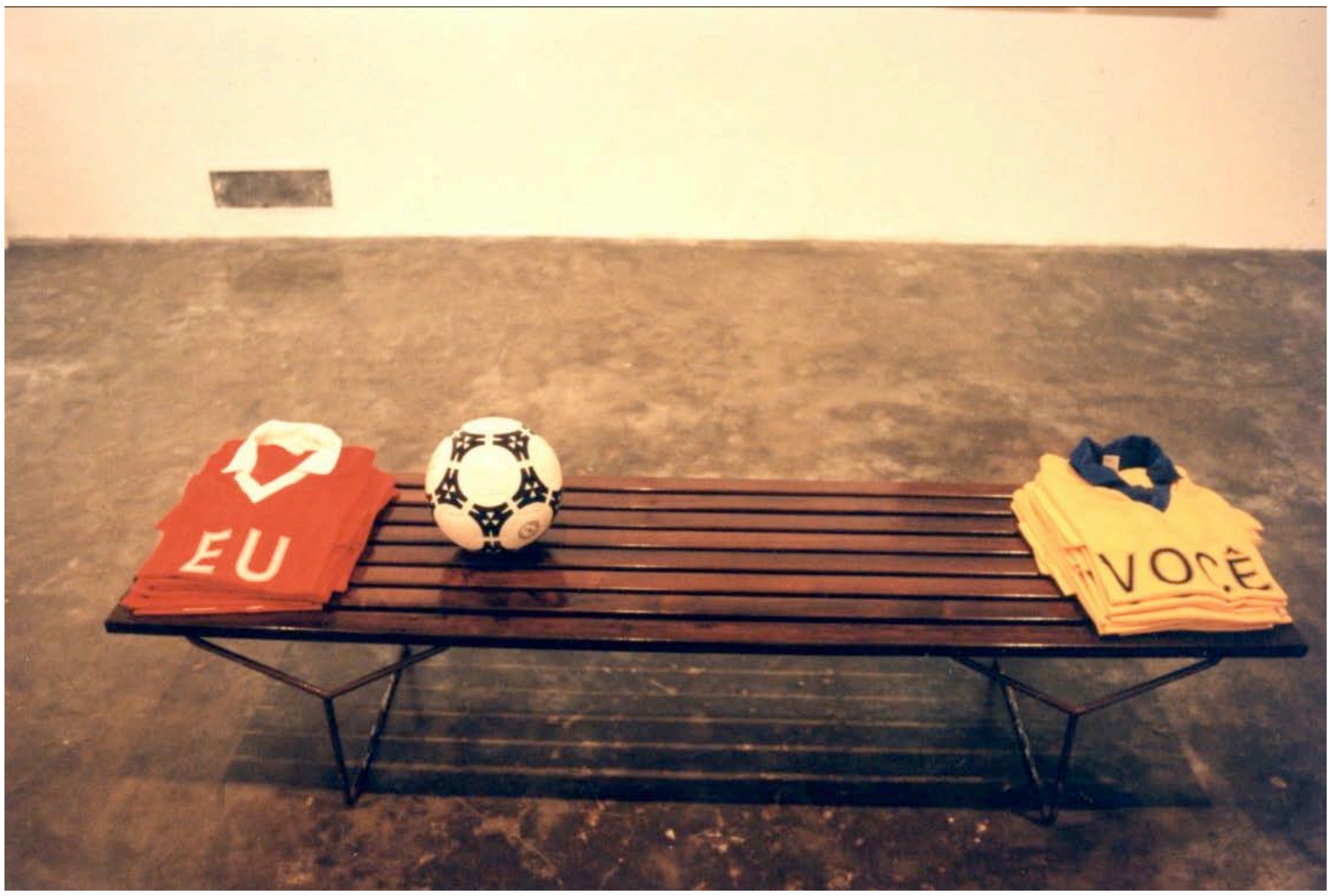

Figura 34 Ricardo Basbaum, eu-você, jogos, exercícios e coreografias, 1997 


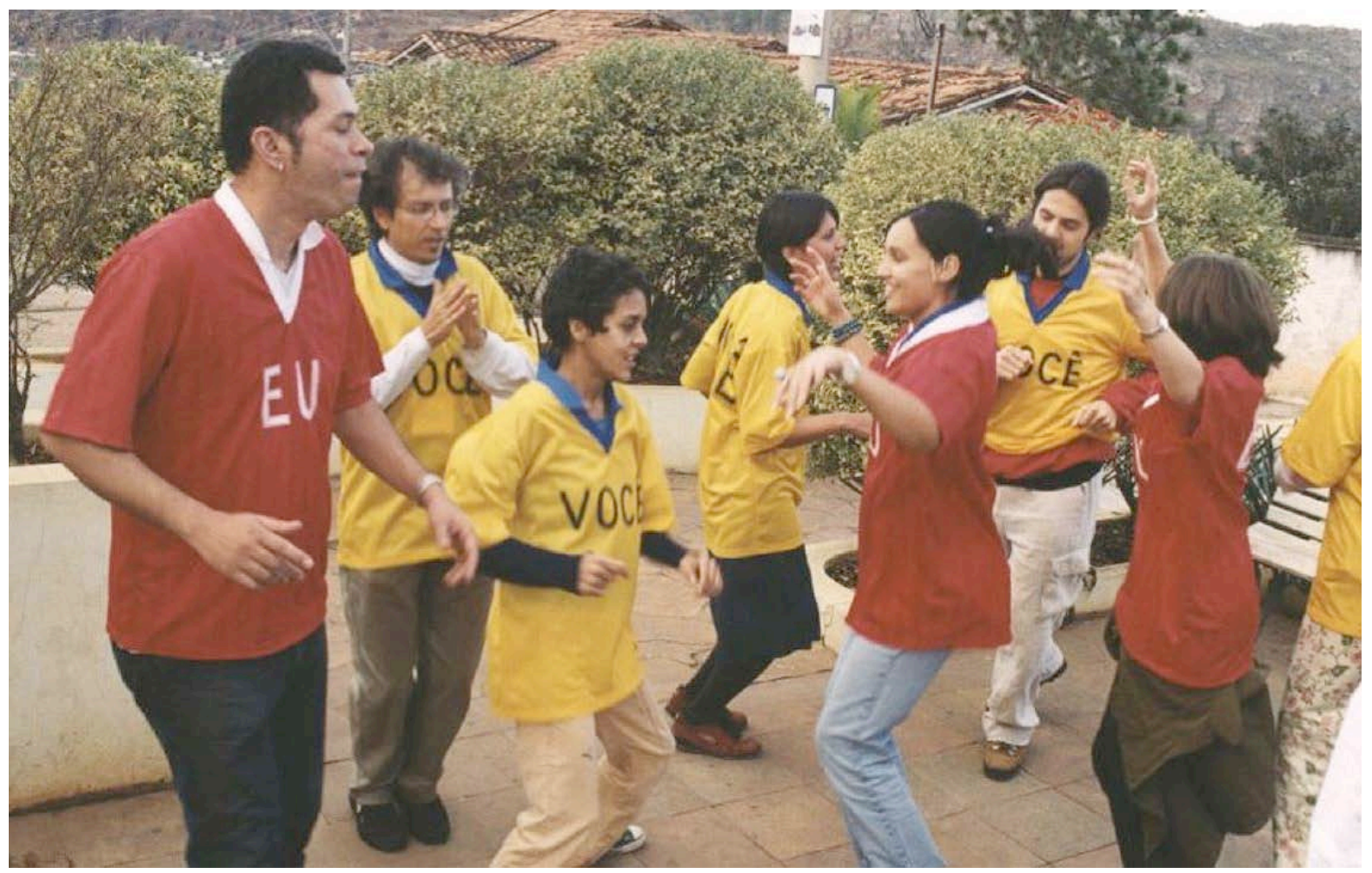

Figura 35 Ricardo Basbaum, eu-você, jogos, exercícios e coreografias, 2000 Diamantina, MG 


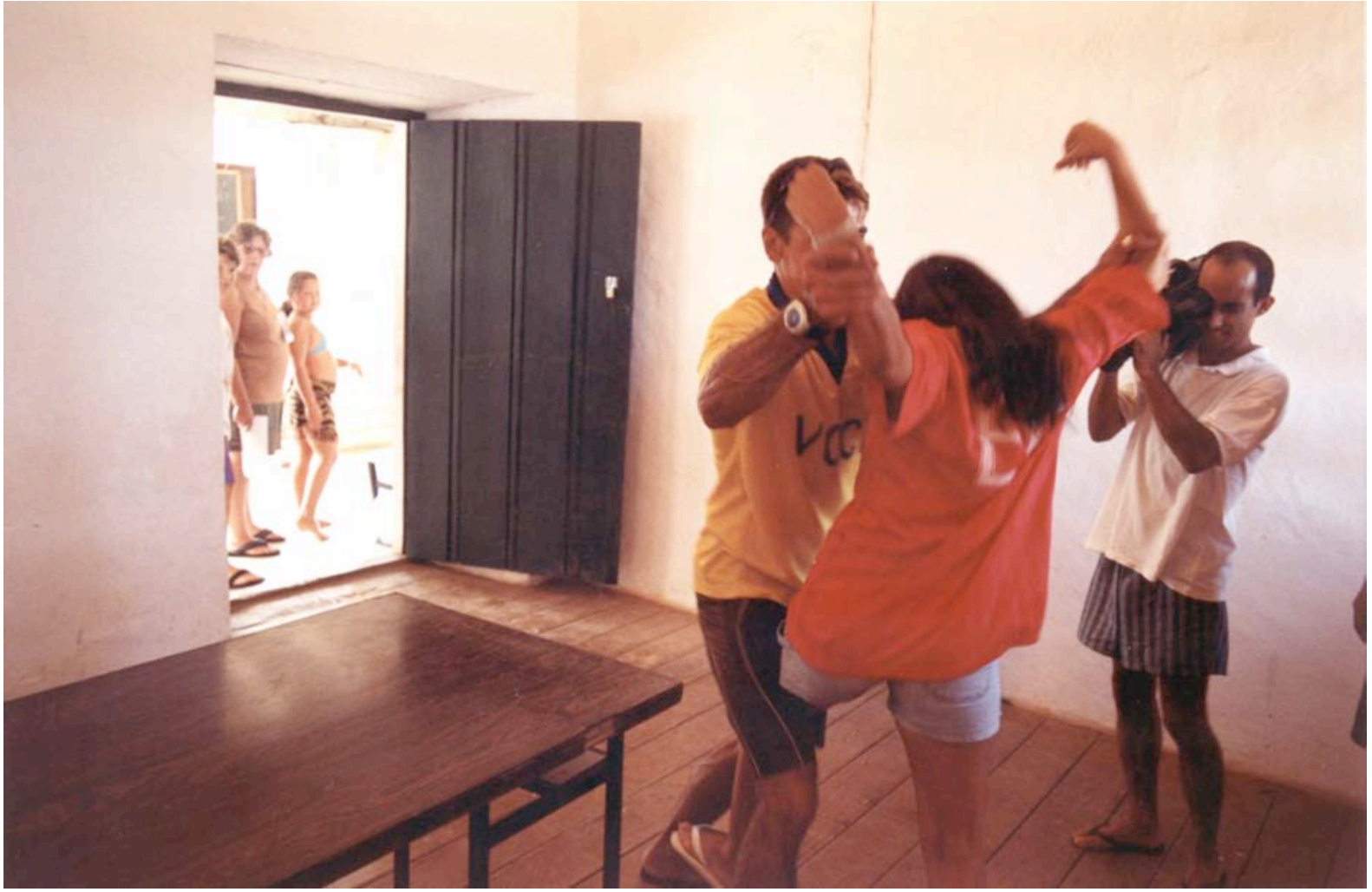

Figura 36 Ricardo Basbaum, eu-você, jogos, exercícios e coreografias, 1999 Nova Almeida, ES 


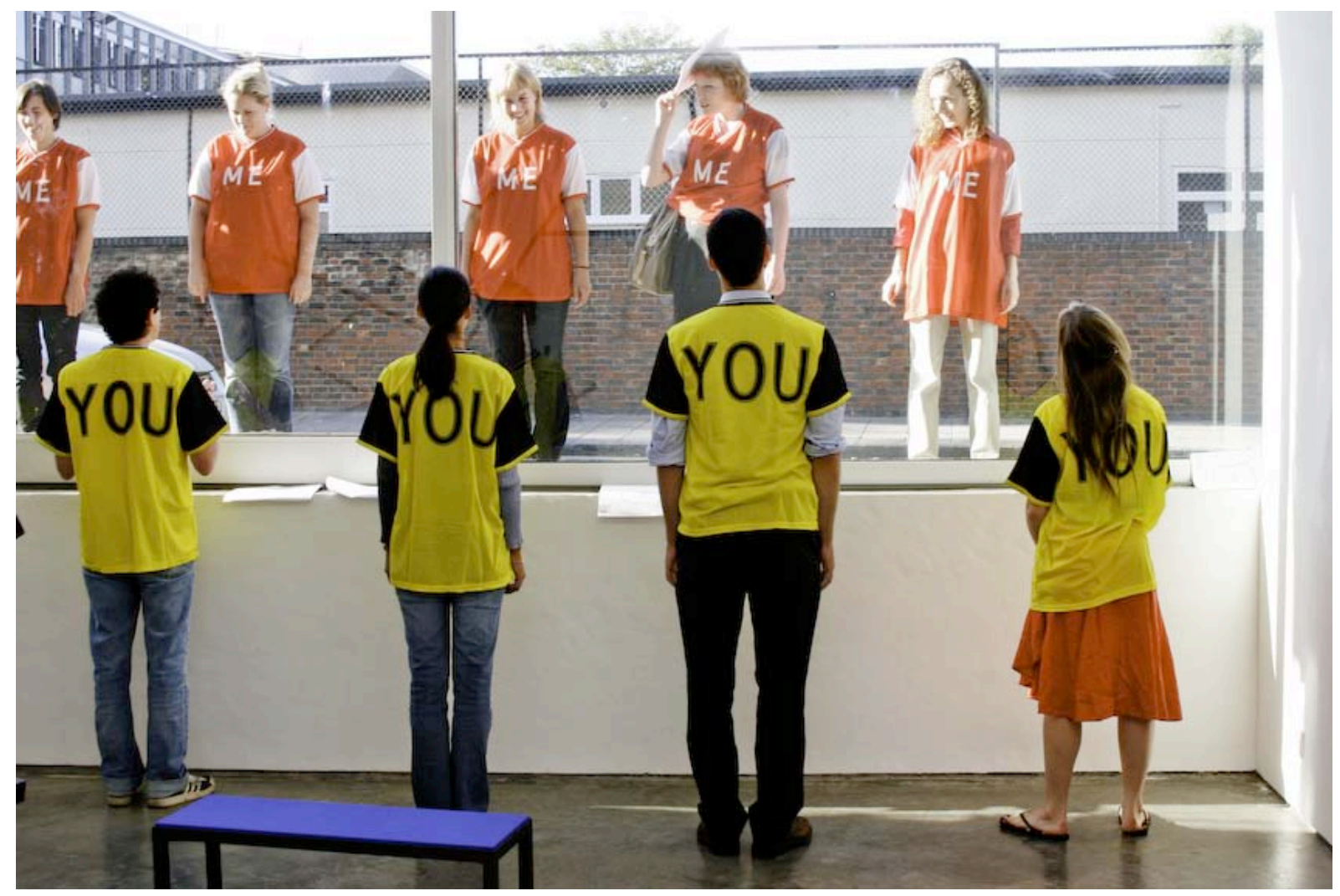

Figura 37 Ricardo Basbaum, eu-você, jogos, exercícios e coreografias, 2007 Lisson Gallery, Londres 


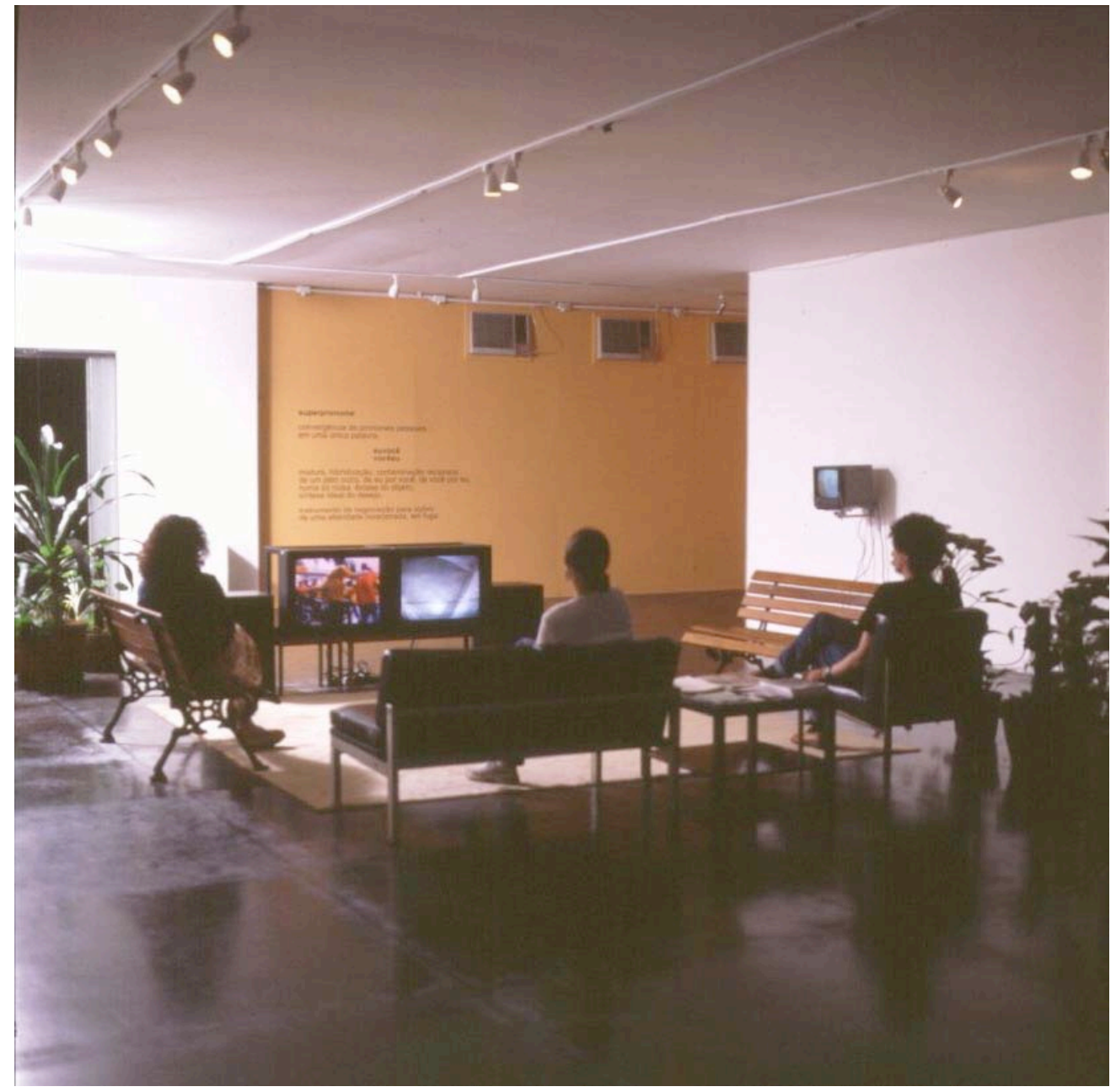

Figura 38 Ricardo Basbaum, re-projetando + sistema-cinema + superpronome, 2003 Galeria Cândido Portinari, UERJ 


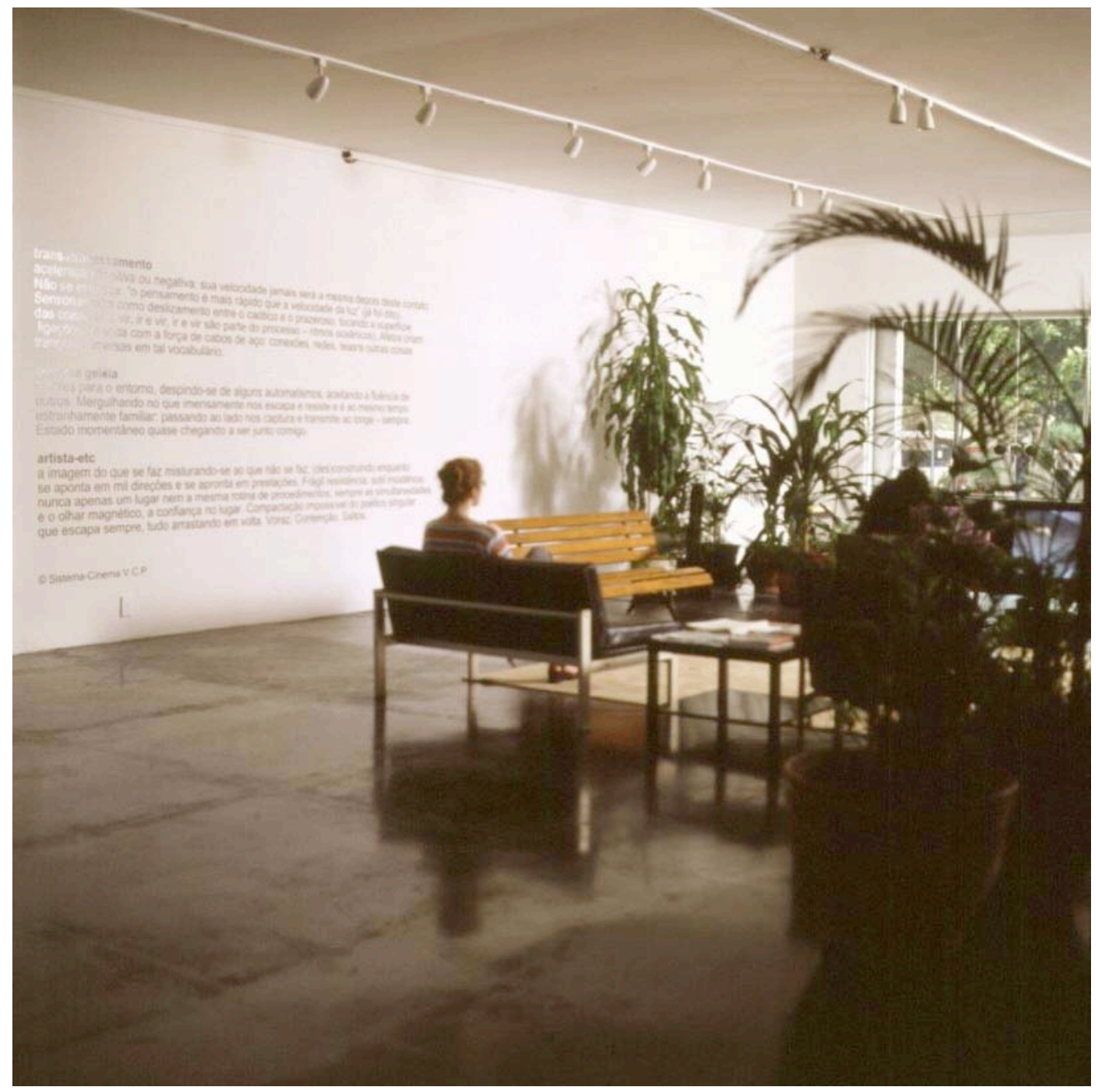

Figura 39 Ricardo Basbaum, re-projetando + sistema-cinema + superpronome, 2003 Galeria Cândido Portinari, UERJ 


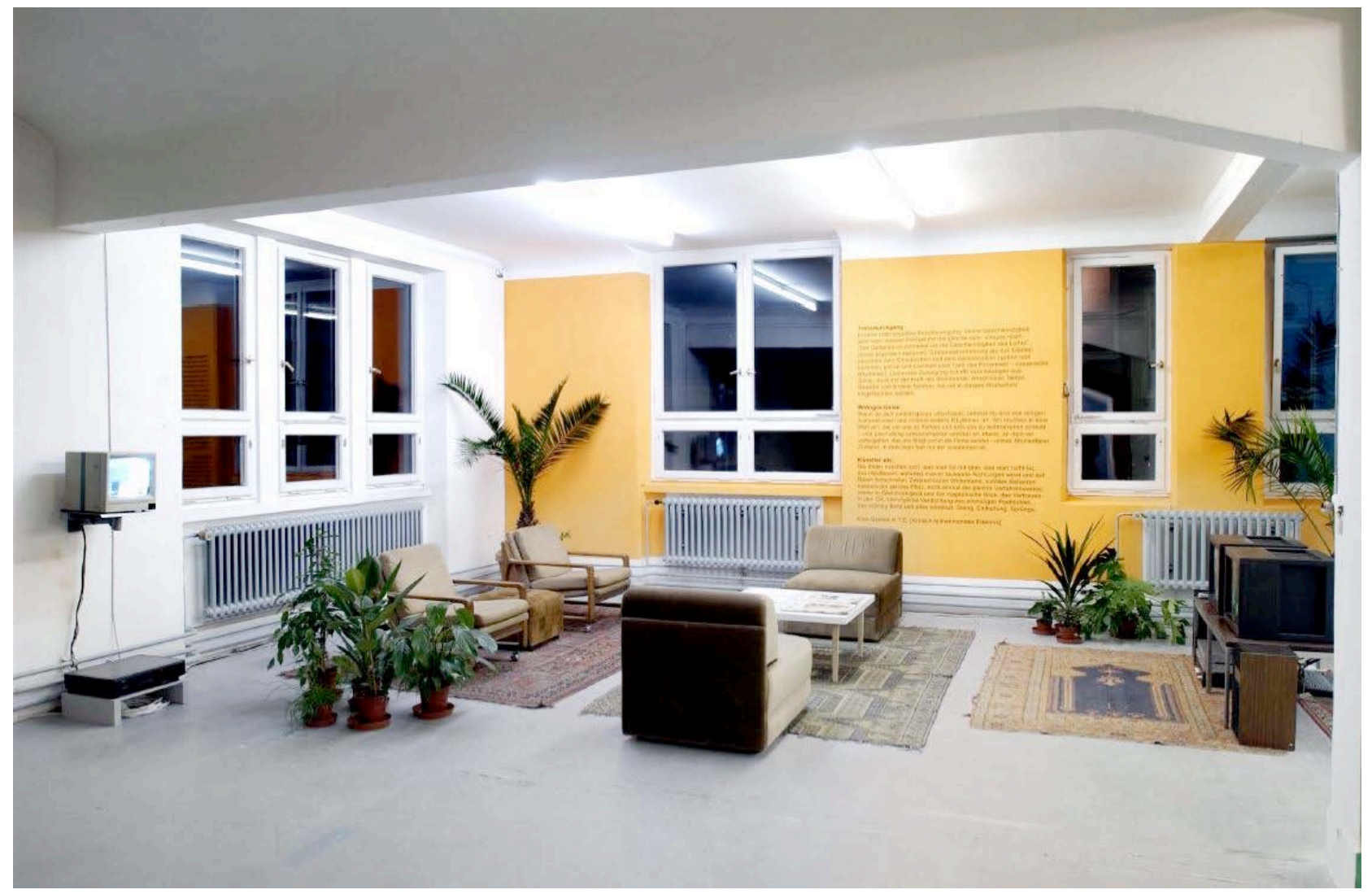

Figura 40 Ricardo Basbaum, sistema-cinema, 2005 Künstlerhaus Stuttgart 
Transdurchgang

positive oder negative Beschleunigung: Deine Geschwindigkeit wird nach diesem Kontakt nie die gleiche sein. Vergiss nicht: Der Gedanke ist schneller als die Geschwindigkeit des Lichts" (es ist allgemein bekannt). Sinneswahrnehmung als das Gleiten zwischen dem Chaotischen und dem Genussvollen (gehen und kommen, gehen und kommen sind Teile des Prozesses - ozeanische Rhythmen). Liebevolle Zuneigung schafft Verbindungen aus Seide, doch mit der Kraft der Stahldrähte: Anschlüsse, Netze, Gewebe und andere Sachen, die tief in diesem Wortschatz eingeflochten werden.

\section{Widriges Gelee}

Wenn du dich einmal genau umschaust, befreist du dich von einigen Automatismen und nimmst andere Rhythmen an. Wir tauchen in eine Welt ein, die vor uns zu fliehen und sich uns zu widerstreben scheint - und gleichzeitig seltsamerweise vertraut ist: etwas, an dem wir vorbeigehen, das uns fängt und in die Ferne sendet - immer. Momentaner Zustand, in dem man fast mit mir zusammen ist.

\section{Künstler-etc.}

Die Bilder mischen sich: was man tut mit dem, was man nicht tut; das (Ab)Bauen, während man in tausende Richtungen weist und auf Raten fortschreitet. Zerbrechlicher Widerstand, subtiles Beharren: niemals der gleiche Platz, nicht einmal die gleiche Verfahrensweise; immer in Gleichzeitigkeit und der magnetische Blick, das Vertrauen in den Ort. Unmögliche Verdichtung des einmaligen Poetischen, das ständig flieht und alles mitreisst. Gierig. Einhaltung. Sprünge.

Kino-System K.T.E. [Kritisch-teilnehmendes Erlebnis]
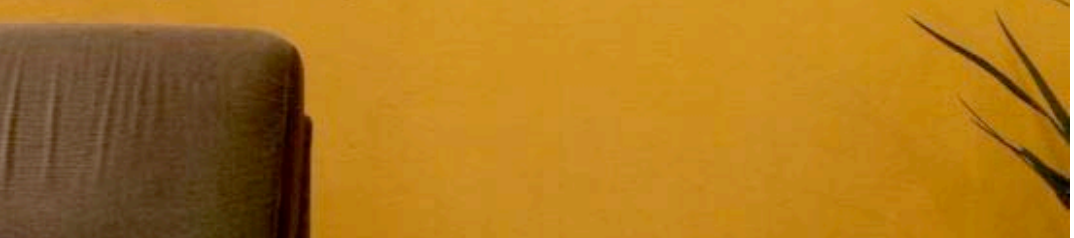

Figura 41 Ricardo Basbaum, sistema-cinema, 2005 Künstlerhaus Stuttgart 

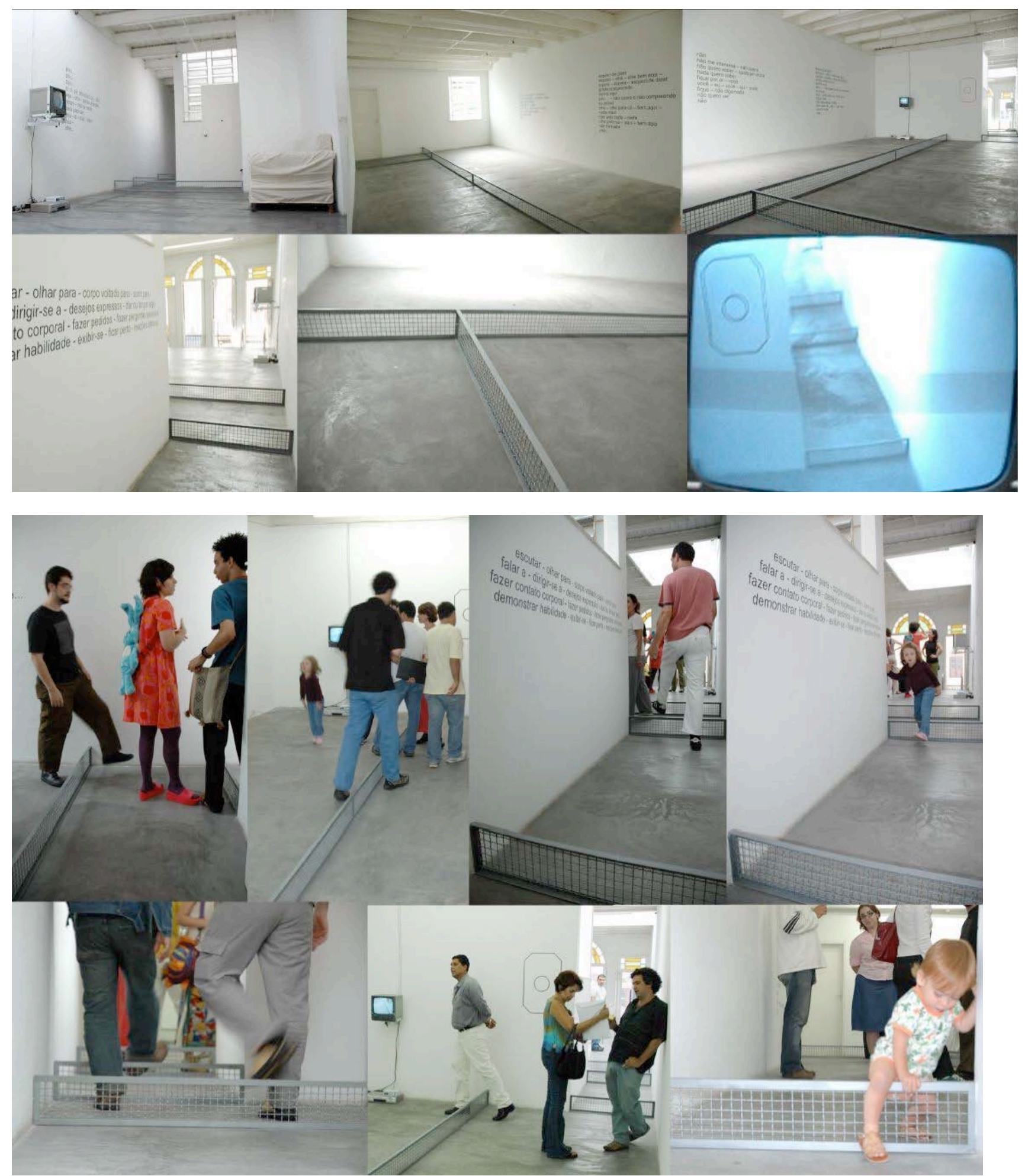

Figura 42 Ricardo Basbaum, obs., 2004

Instalação em A Gentil Carioca 


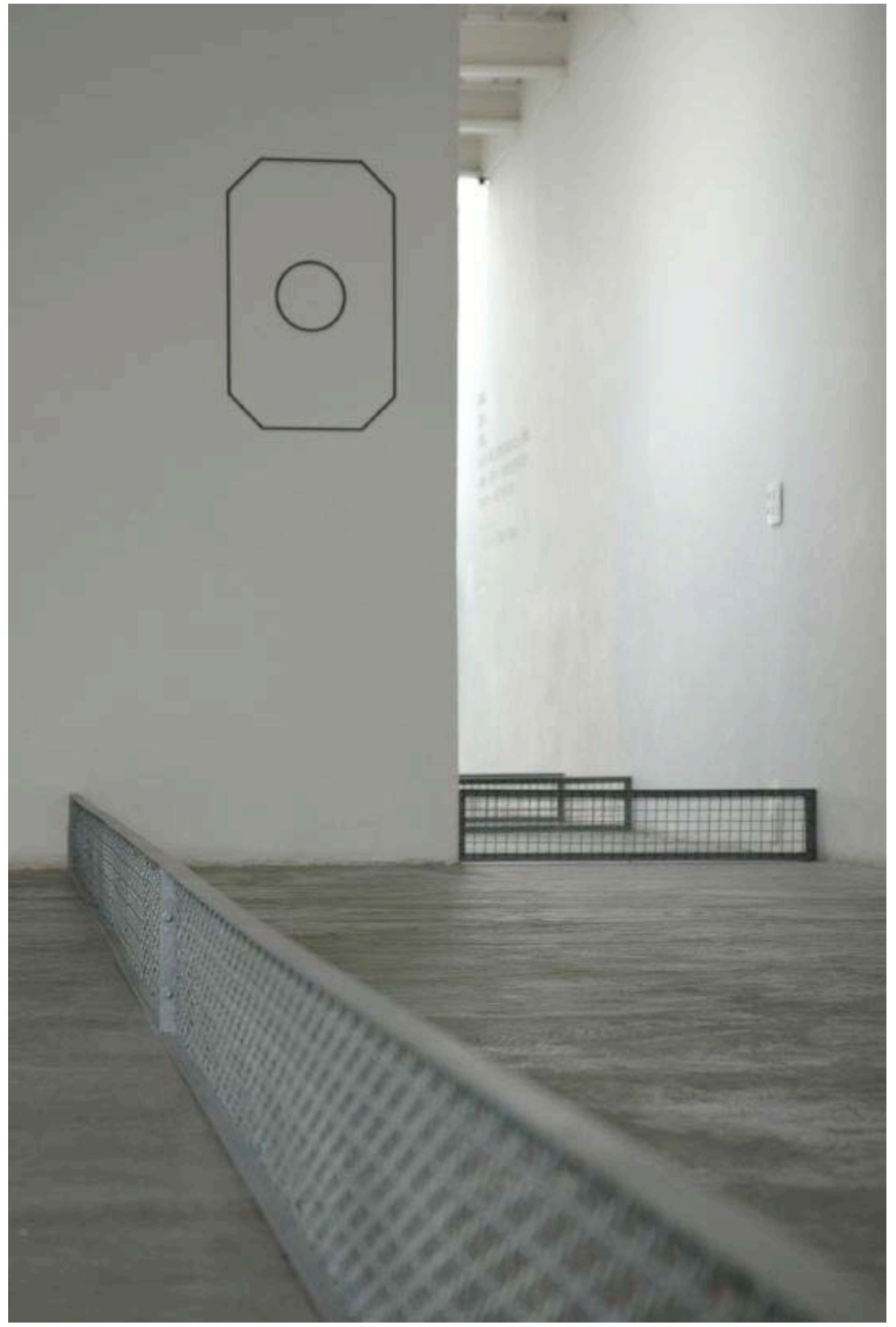

Figura 43 Ricardo Basbaum, obs., 2004 Instalação em A Gentil Carioca 


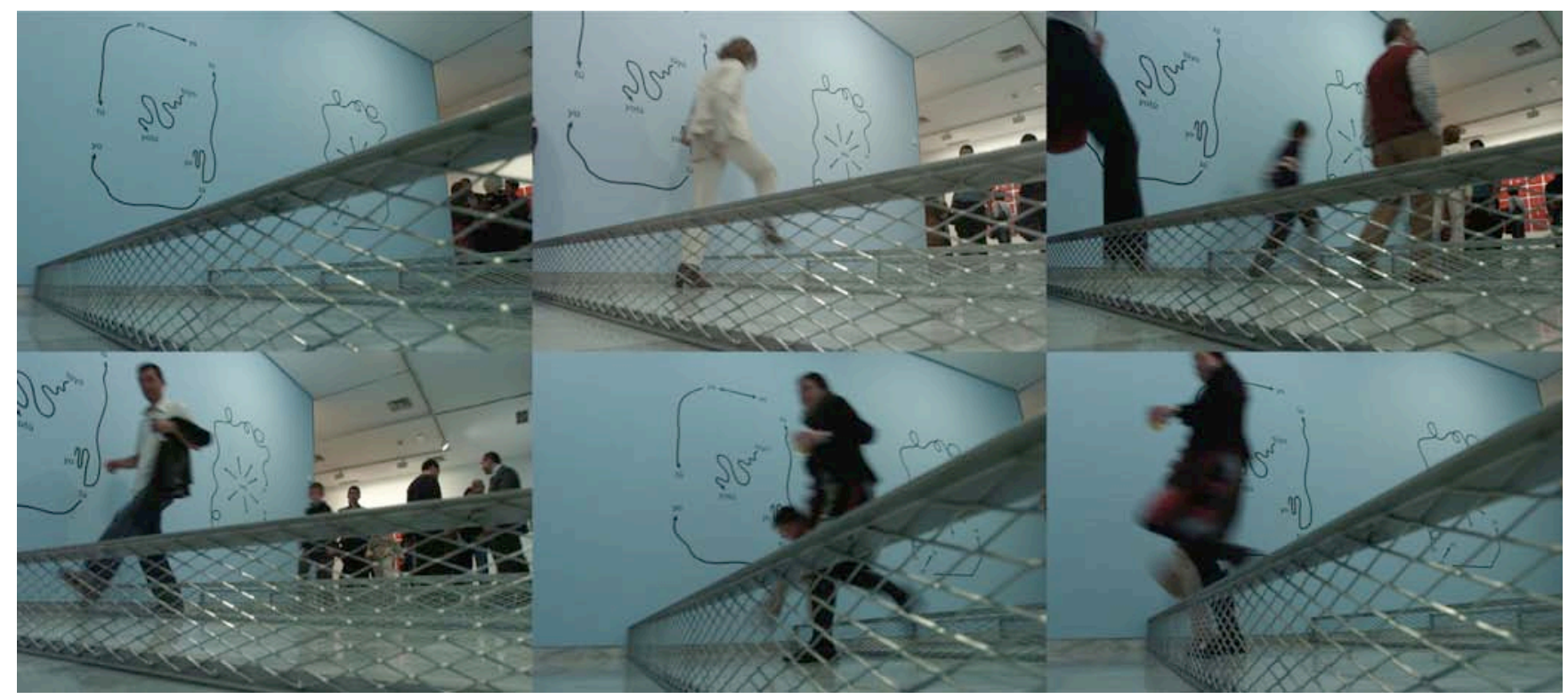

Figura 44 Ricardo Basbaum, obs., 2005

Instalação no CAAM, Las Palmas 


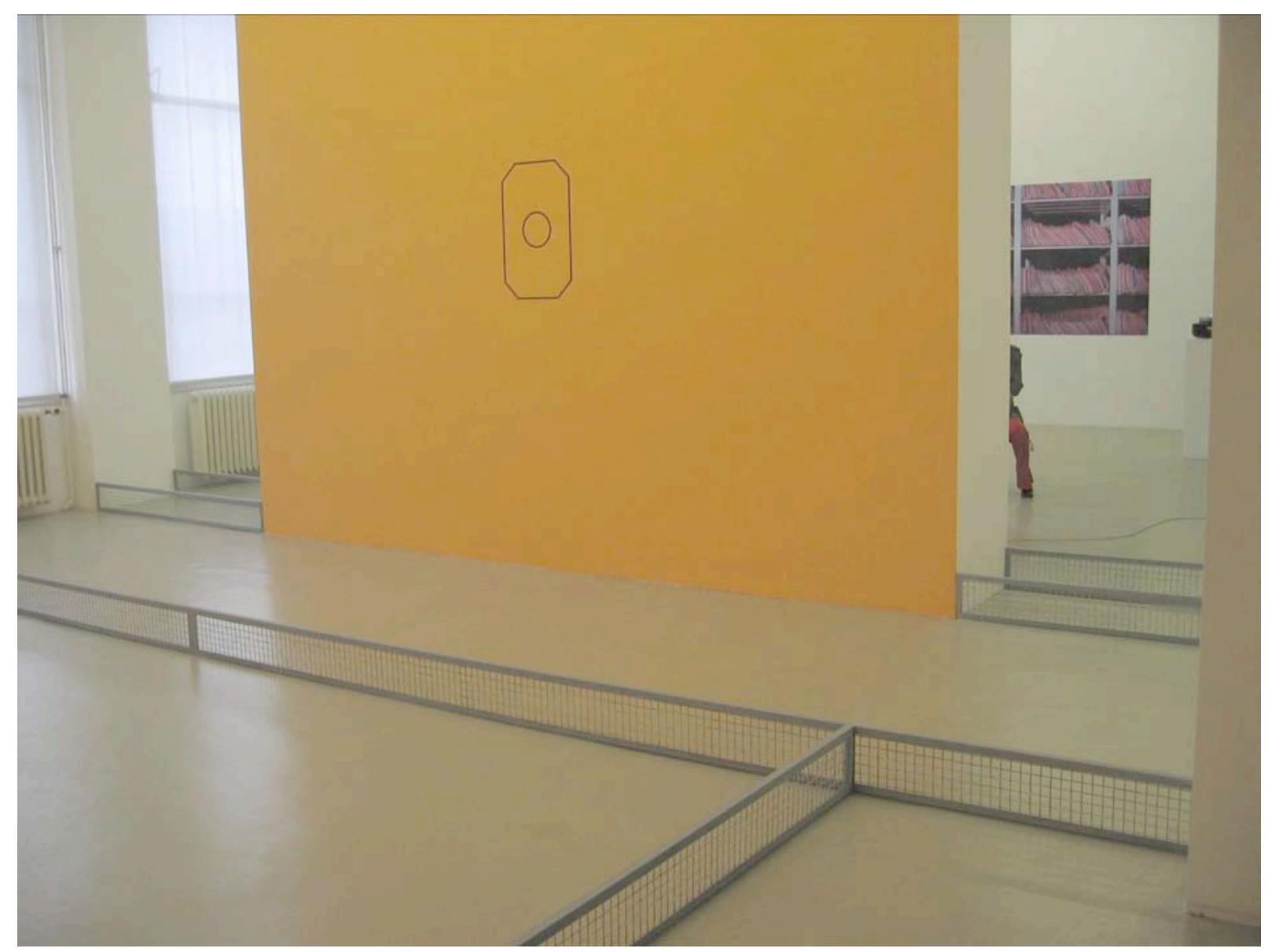

Figura 45 Ricardo Basbaum, obs, 2005, Witte de With, Roterdam 


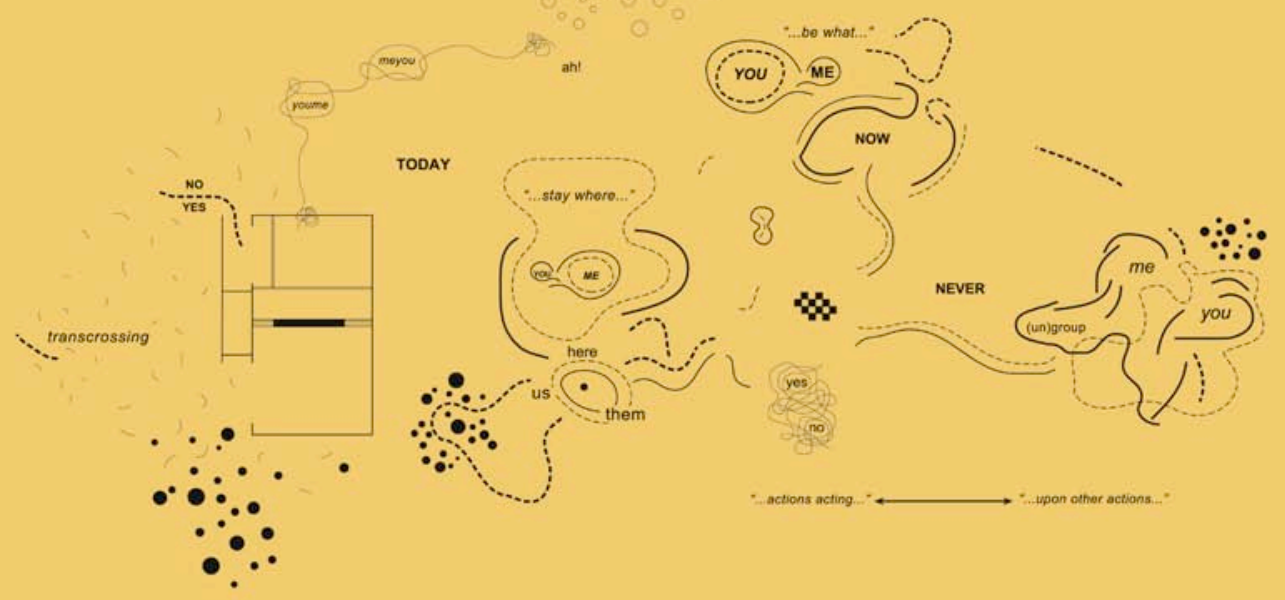

Figura 46 Ricardo Basbaum, diagram (me-you series), 2005 


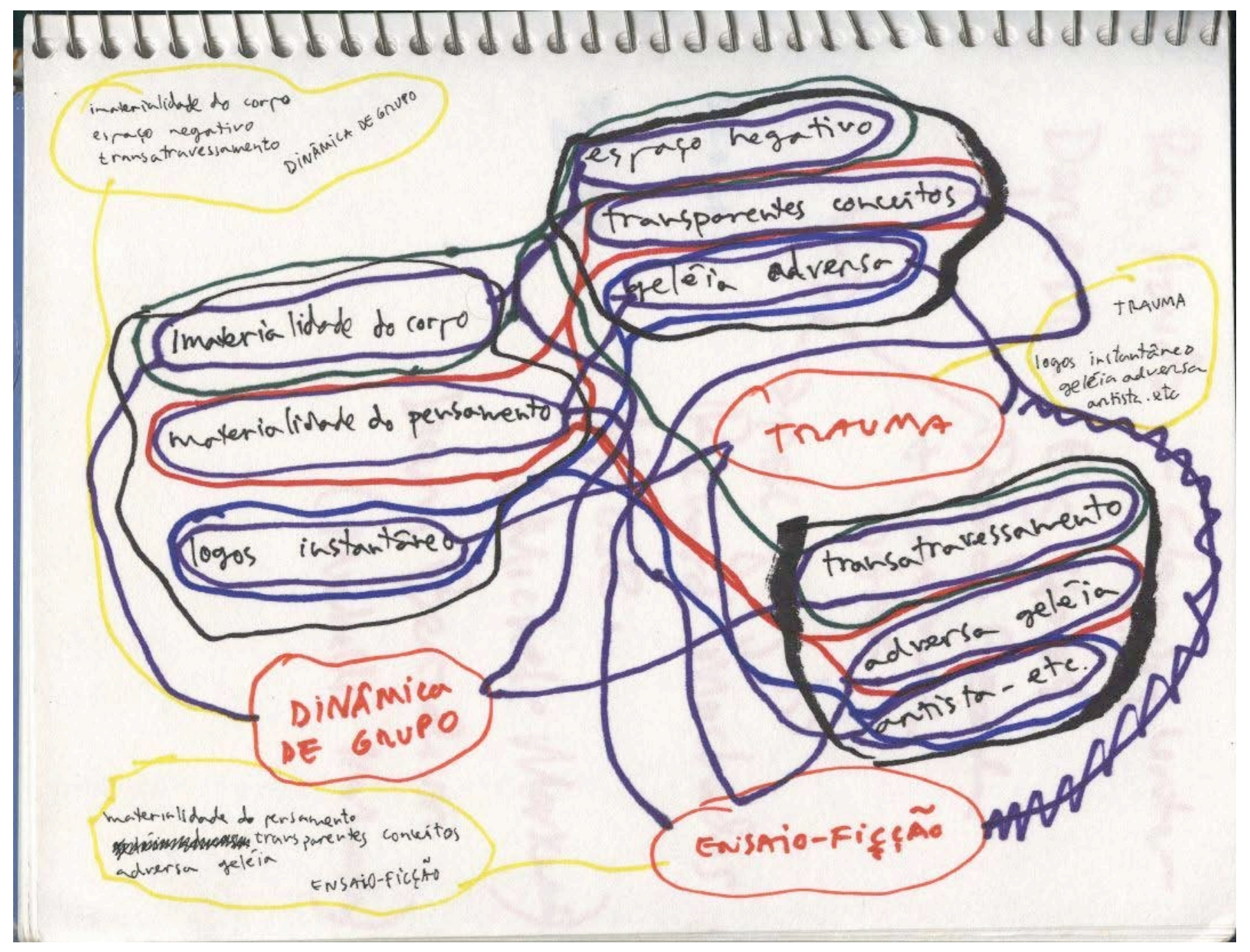

Figura 47 Ricardo Basbaum, tríades (NBP), 2002 


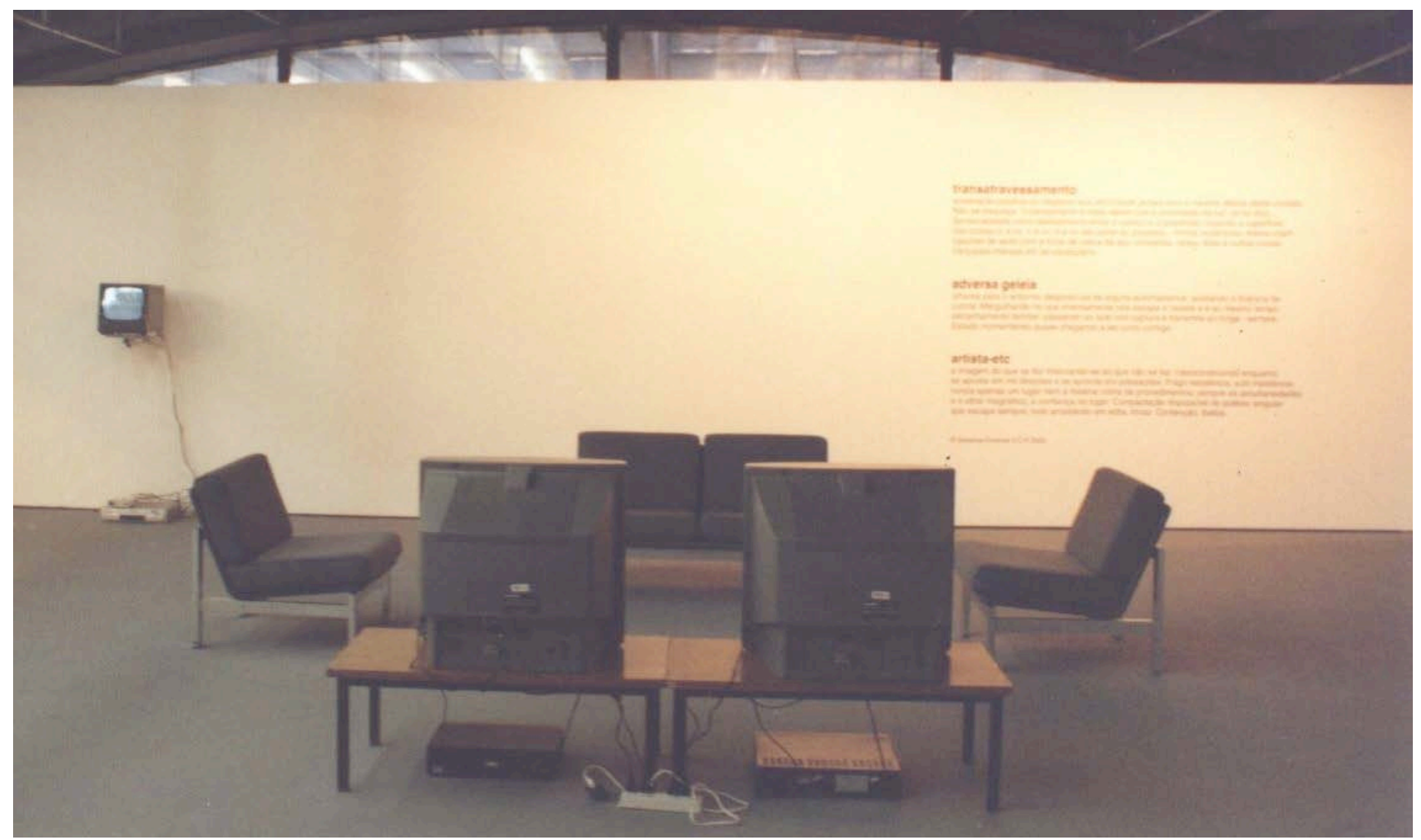

Figura 48 Ricardo Basbaum, sistema-cinema, 2002 Centro Cultural São Paulo 

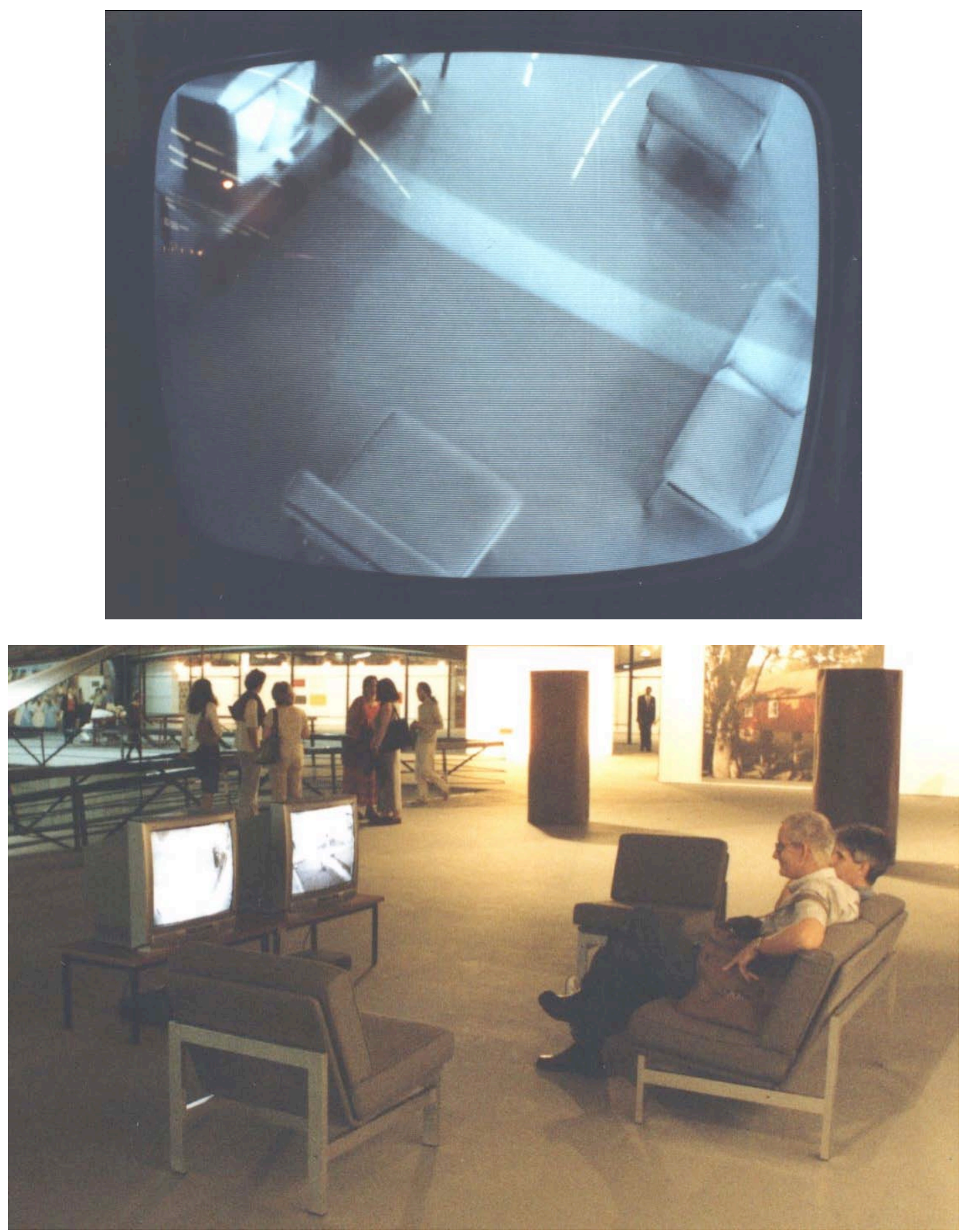

Figura 49 Ricardo Basbaum, sistema-cinema, 2002 Centro Cultural São Paulo 


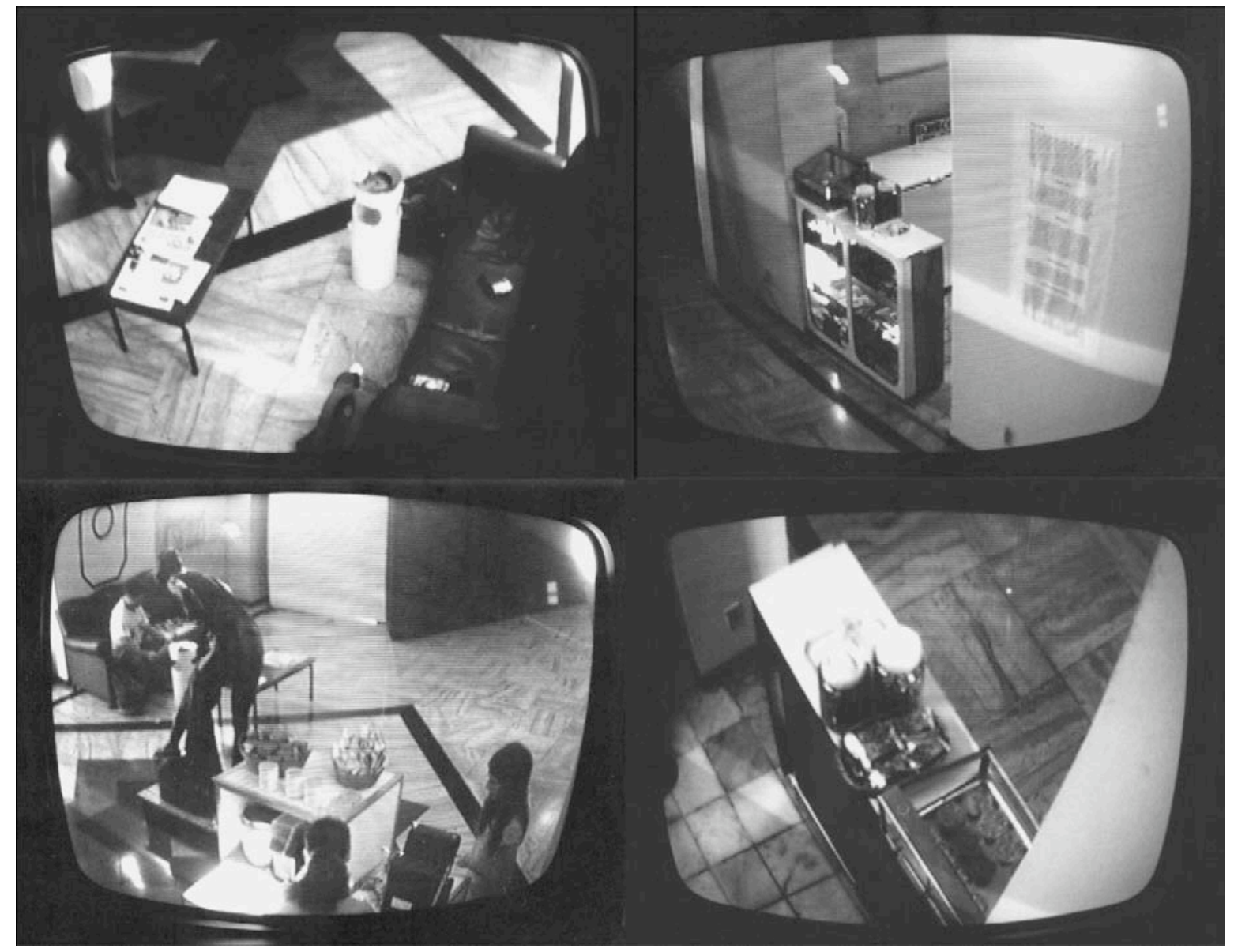

Figura 50 Ricardo Basbaum, sistema-cinema V.C.P., 2002 Interculturalidades, UFF 


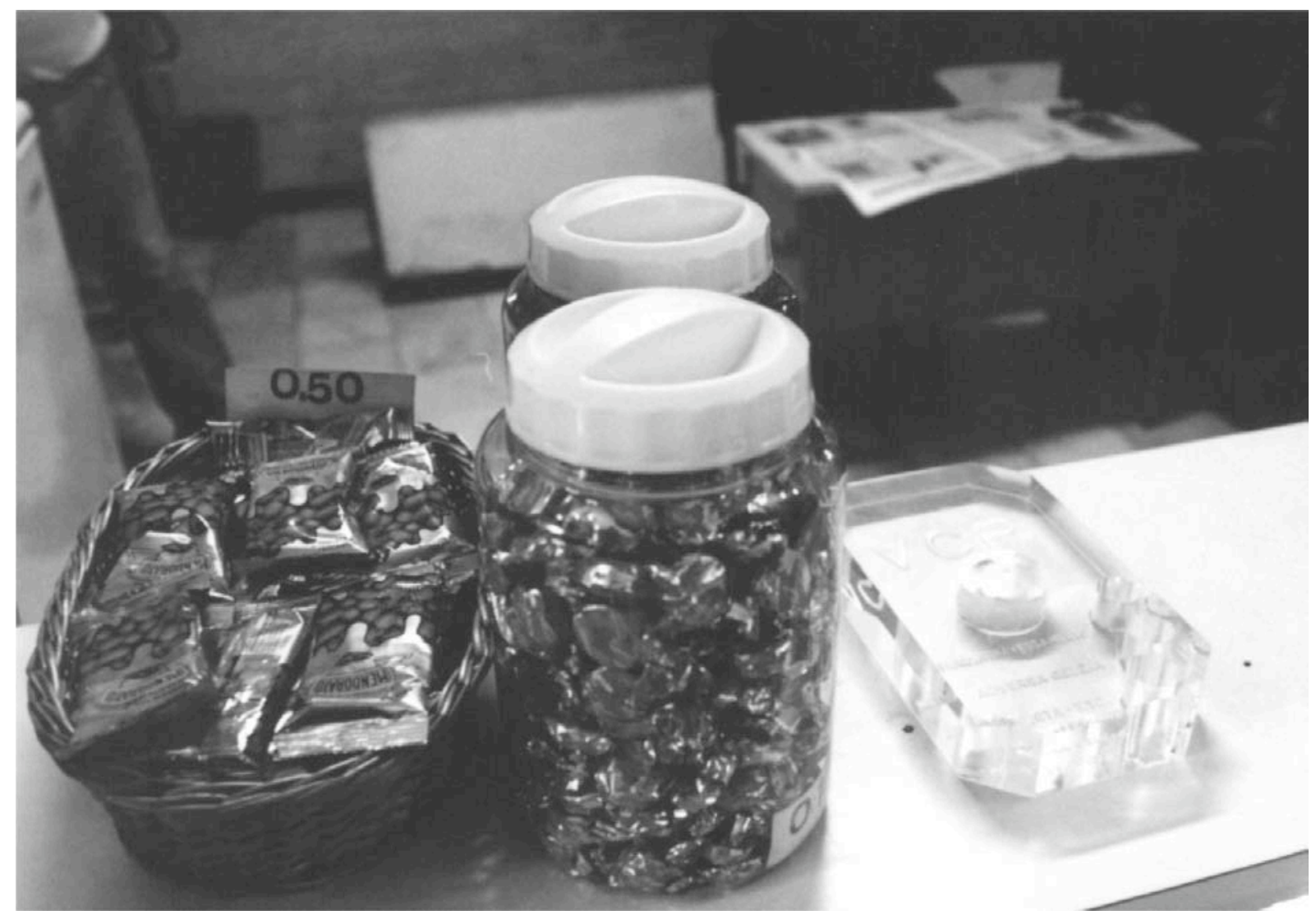

Figura 51 Ricardo Basbaum, sistema-cinema V.C.P., 2002 Interculturalidades, UFF 


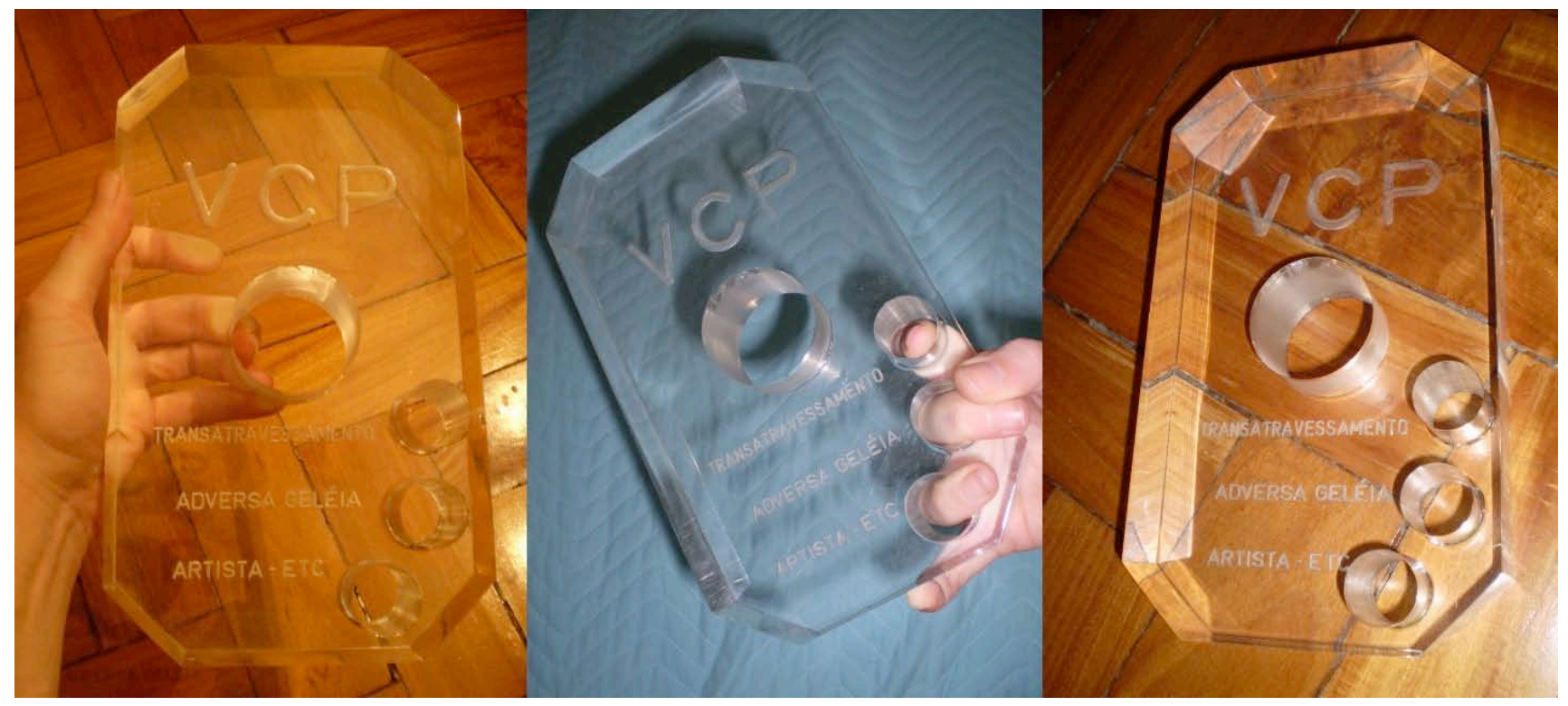

Figura 52 Ricardo Basbaum, objeto V.C.P., 2002 


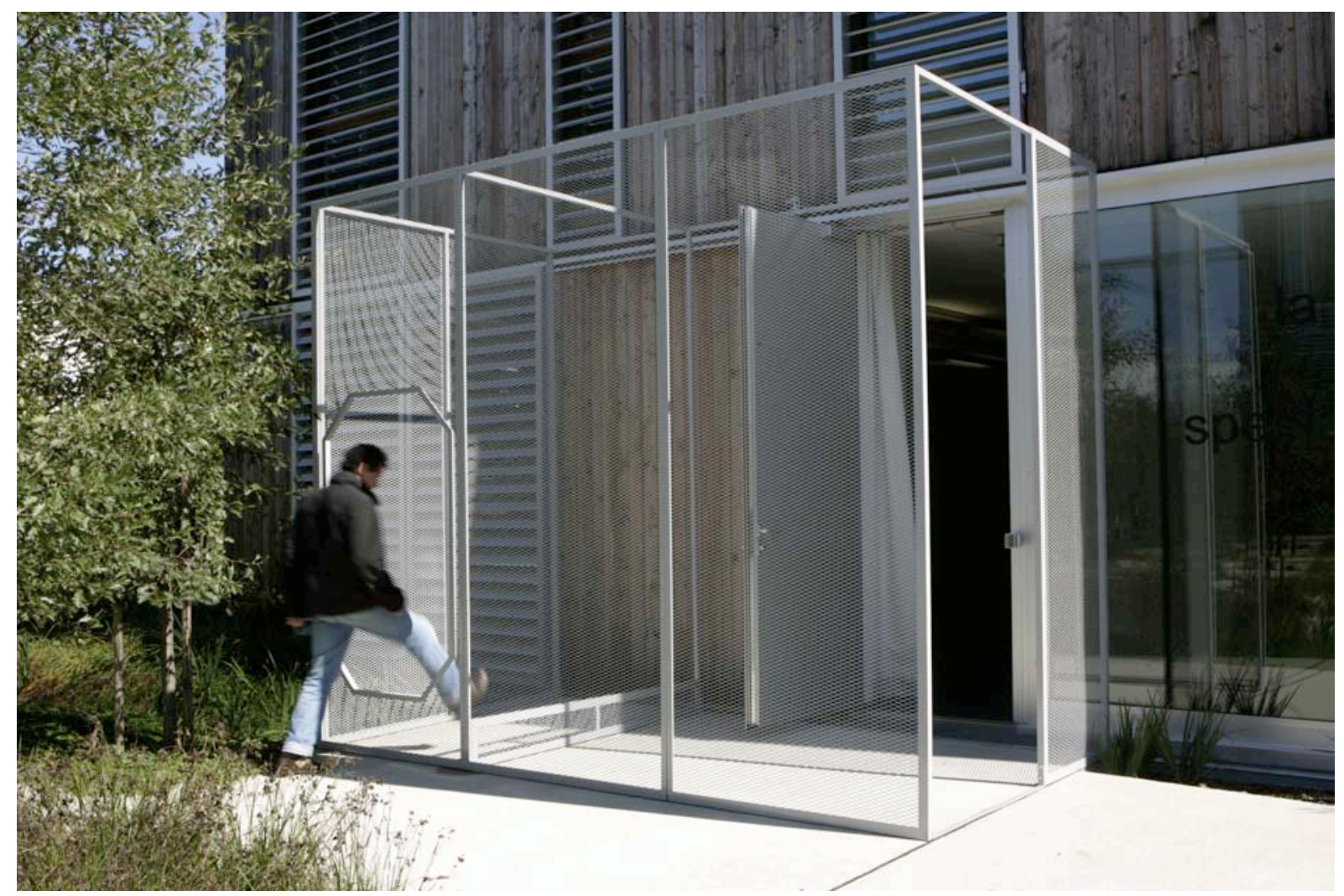

Figura 53 Ricardo Basbaum, la société du spectacle (\& NBP), 2007 Lakeside project, Kalgenfurt, Austria 


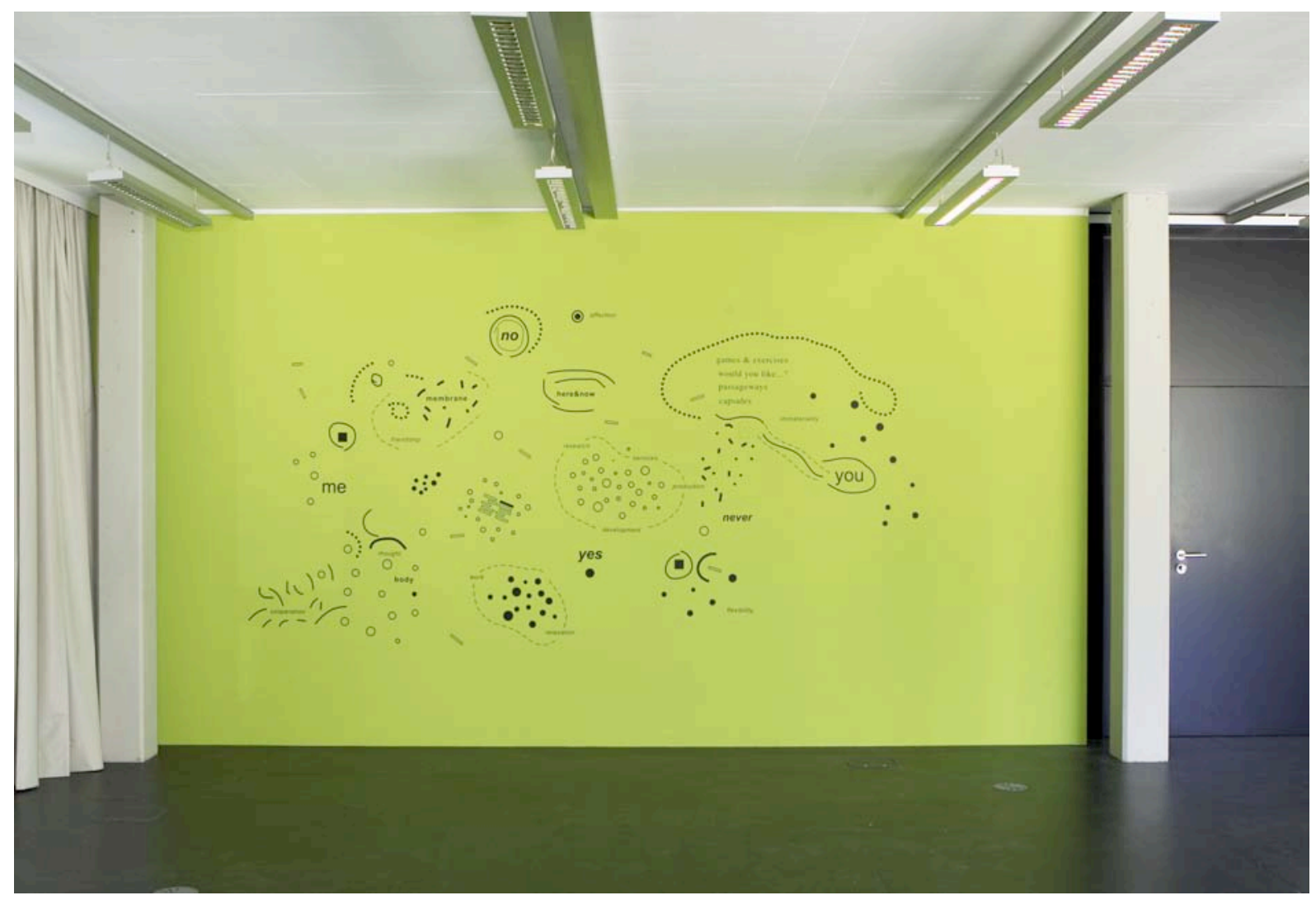

Figura 54 Ricardo Basbaum, diagram [la société du spectacle (\& NBP)], 2007 Lakeside project, Kalgenfurt, Austria 


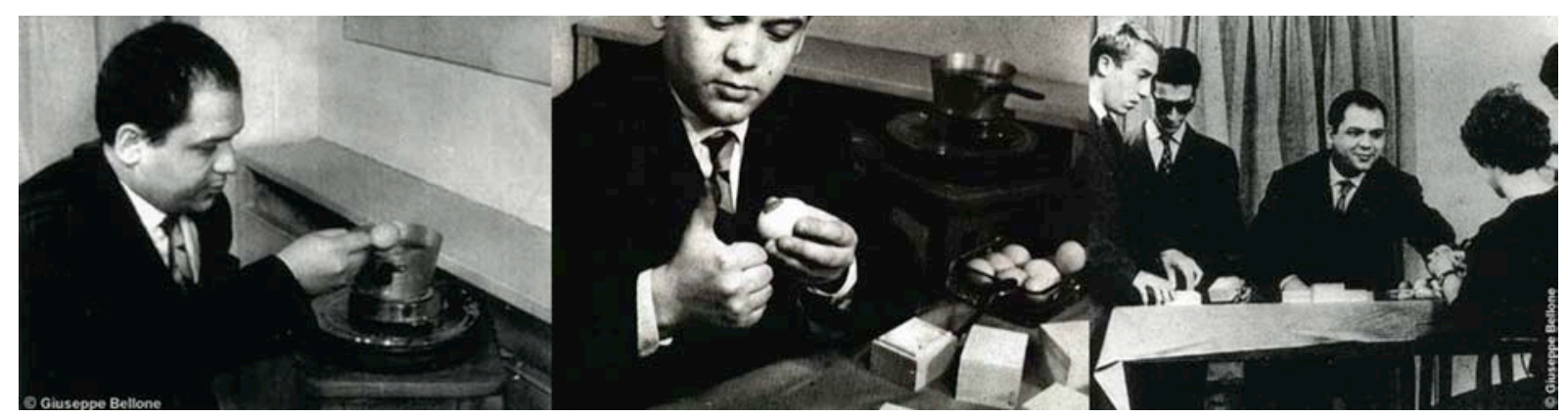

Figura 55 Piero Manzoni, Consumo de arte dinâmica pelo público devorador de arte, 1960

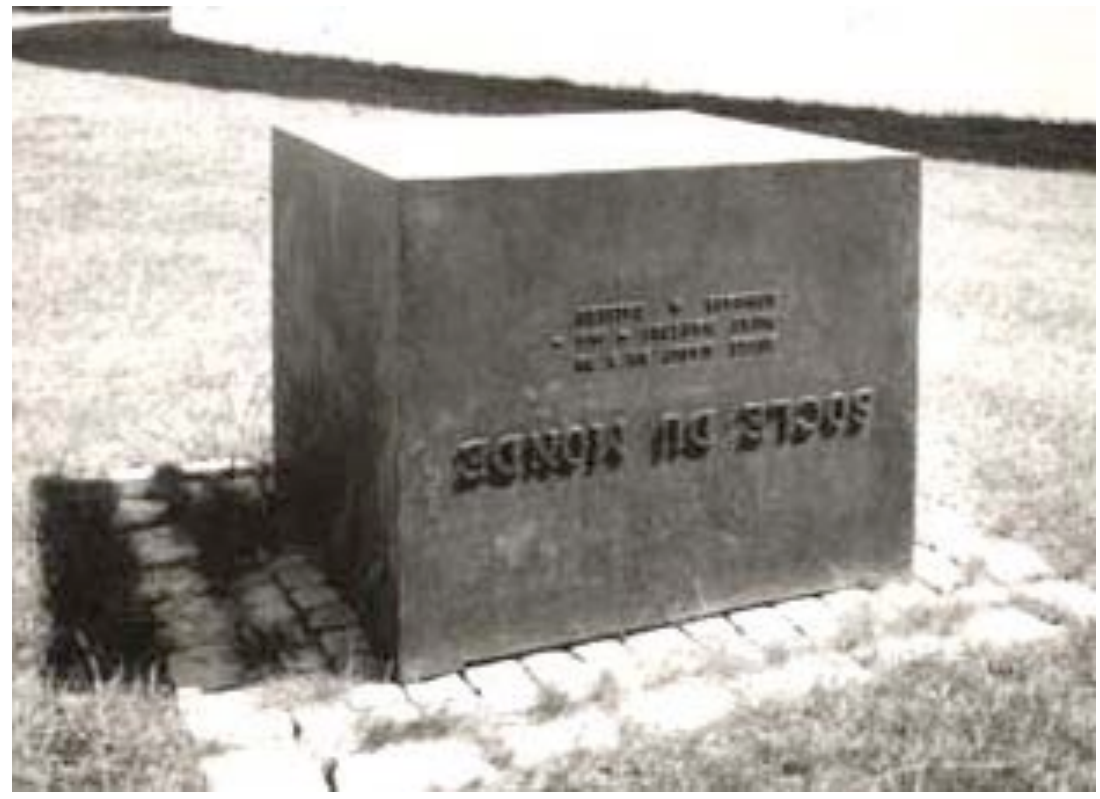

Figura 56 Piero Manzoni, Socle du monde, 1962 


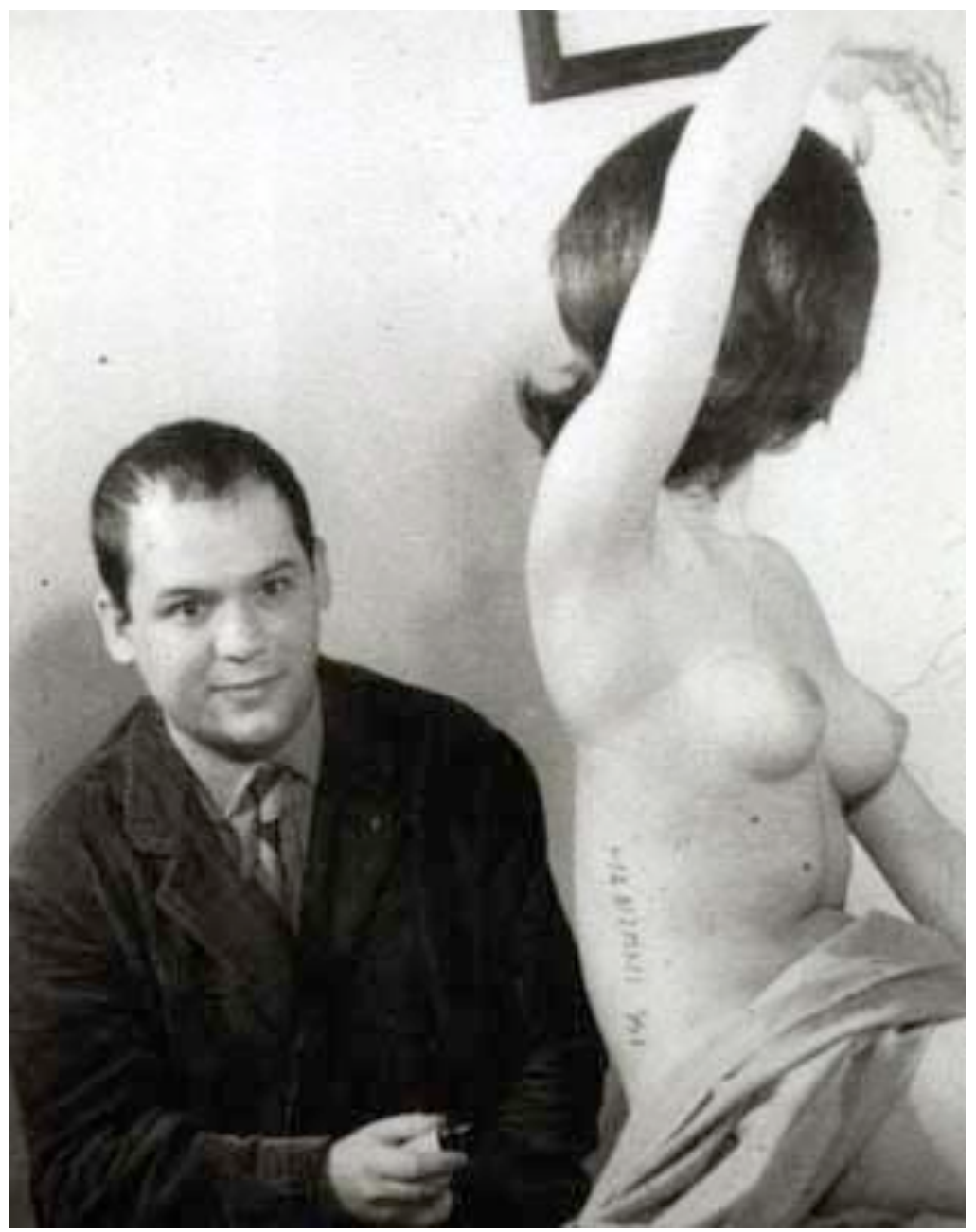

Figura 57 Piero Manzoni, Esculturas vivas, 1961 


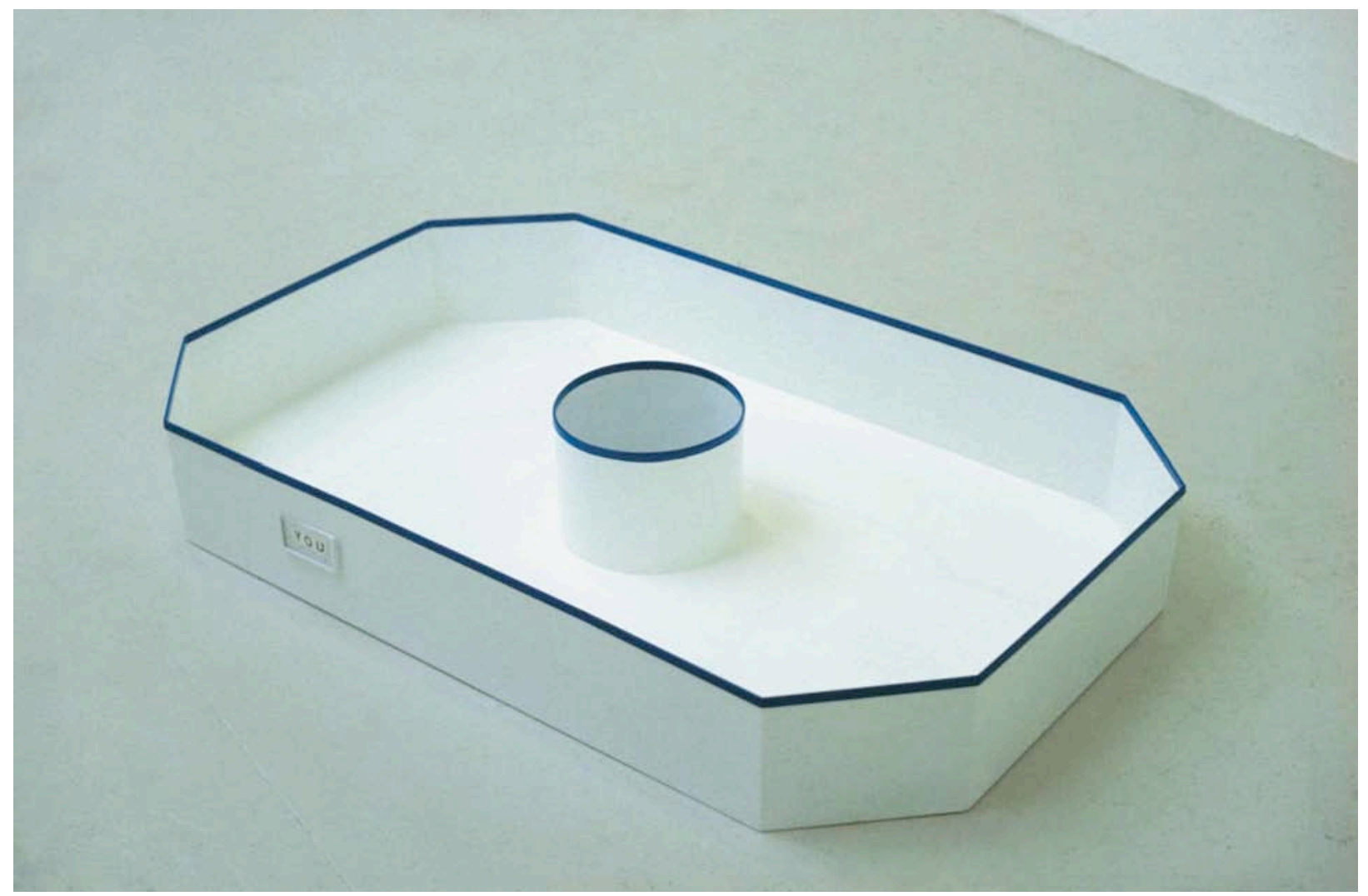

Figura 58 Ricardo Basbaum, Você gostaria de participar de uma experiência artística?, projeto em curso desde 1994 


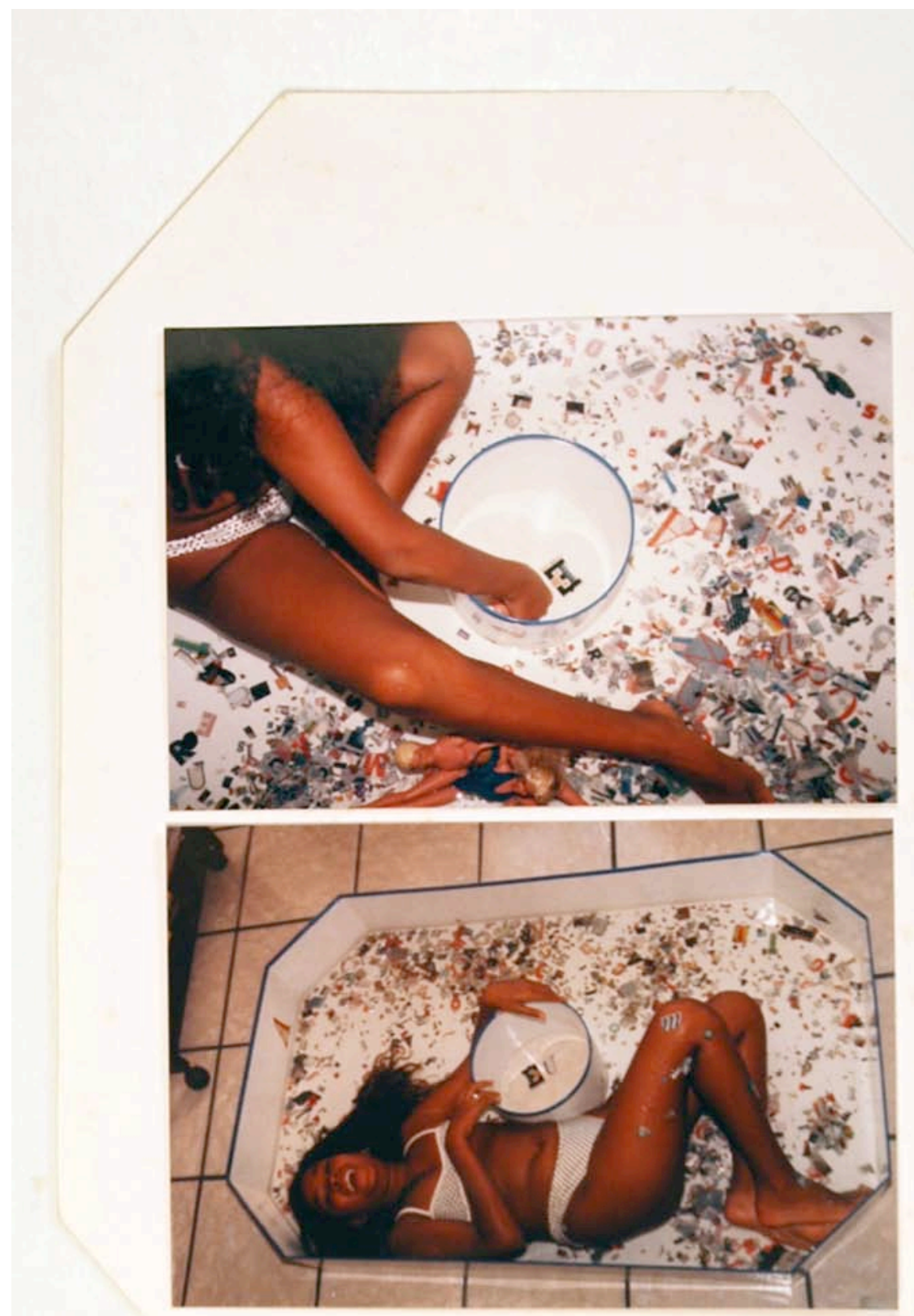

Figura 59 Ricardo Basbaum, Você gostaria de participar de uma experiência artística?, projeto em curso desde 1994

participação Mara Perpétua e Luara, Vitória, 1995 


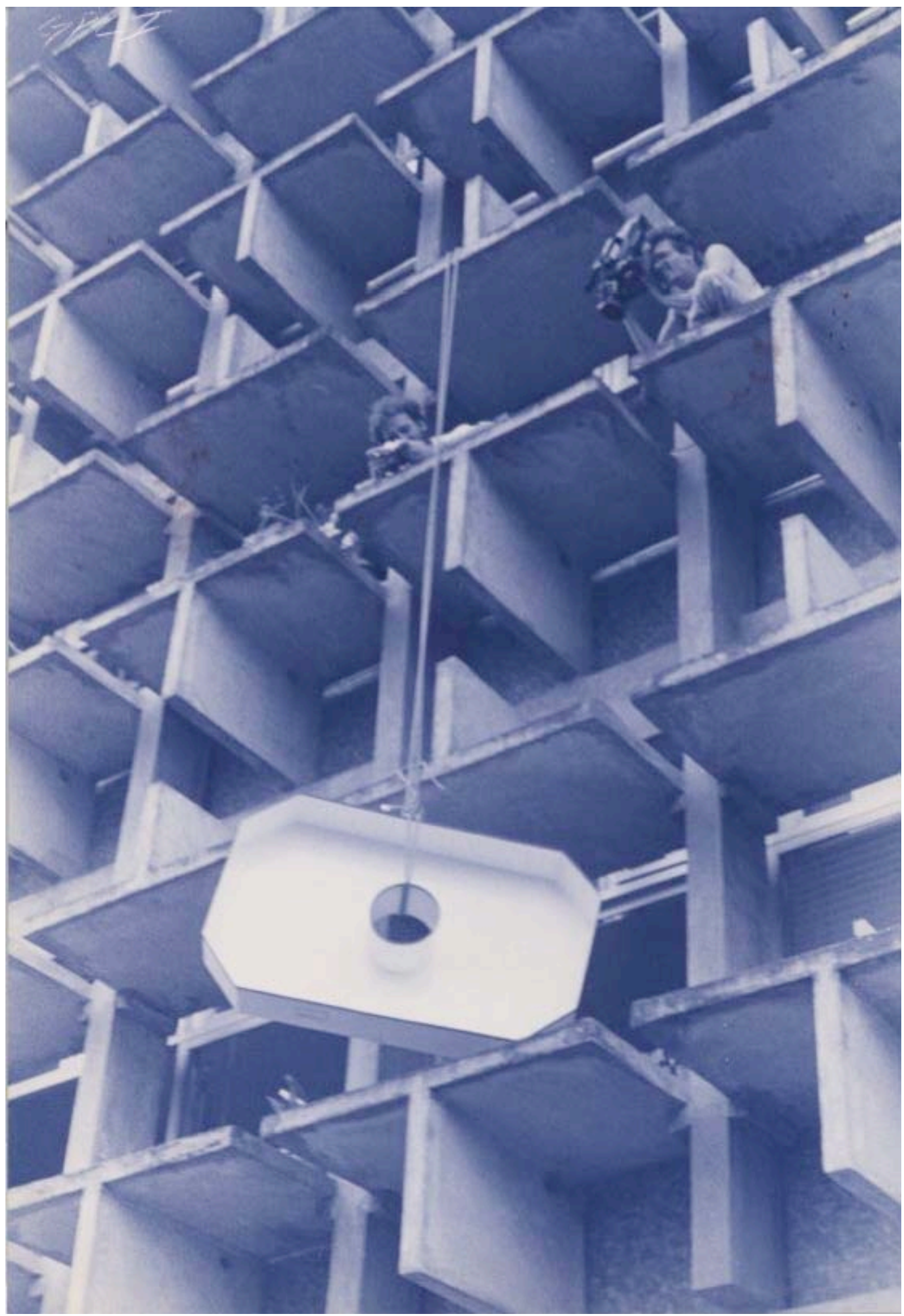

Figura 60 Ricardo Basbaum, Você gostaria de participar de uma experiência artística?, projeto em curso desde 1994

participação Grupo de Pesquisa Corpos Informáticos, Brasília, 1998 


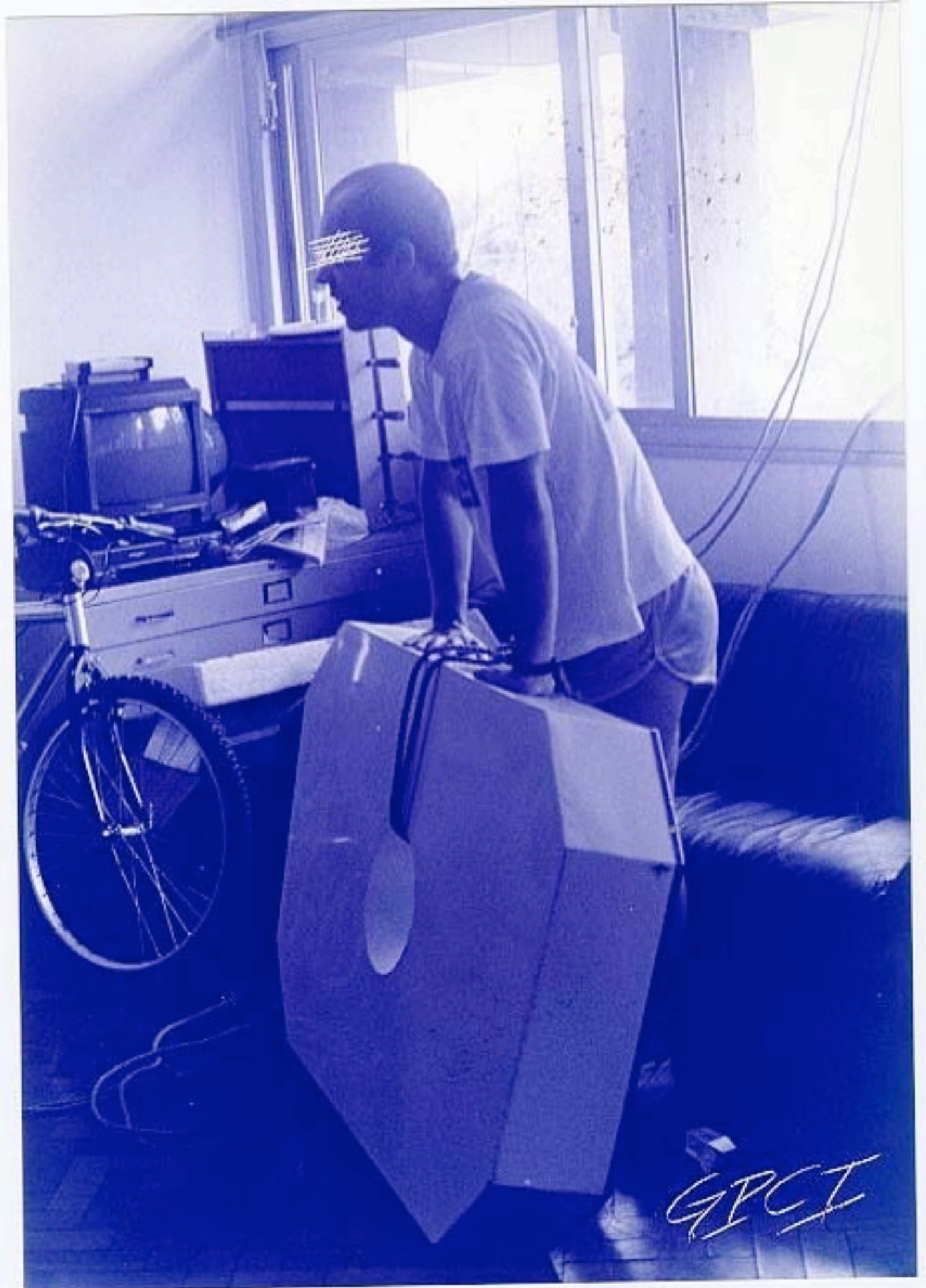

Figura 61 Ricardo Basbaum, Você gostaria de participar de uma experiência artística?, projeto em curso desde 1994

participação Grupo de Pesquisa Corpos Informáticos, Brasília, 1998 


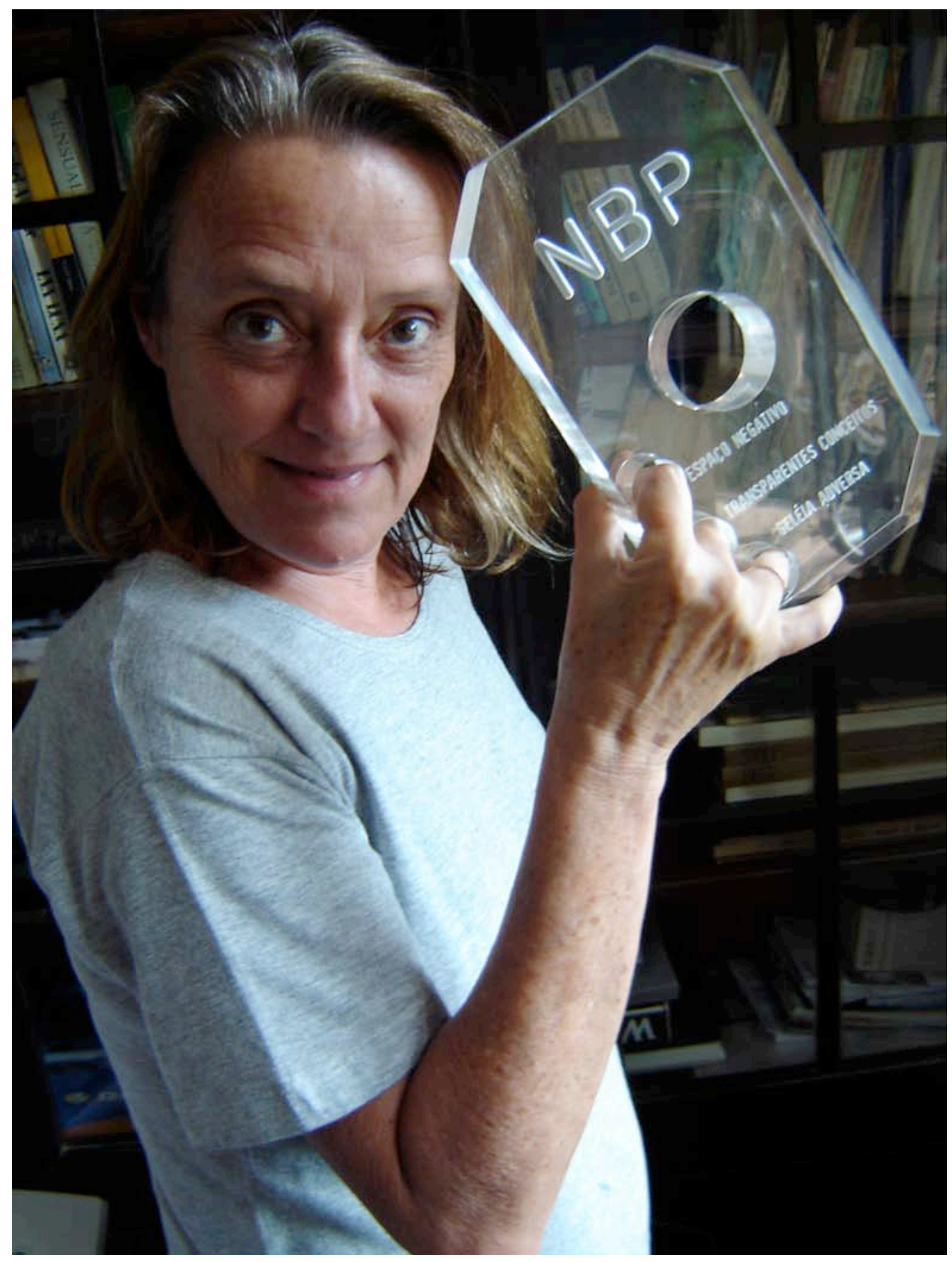

Figura 62 Ricardo Basbaum, objeto espaço negativo, 1998 


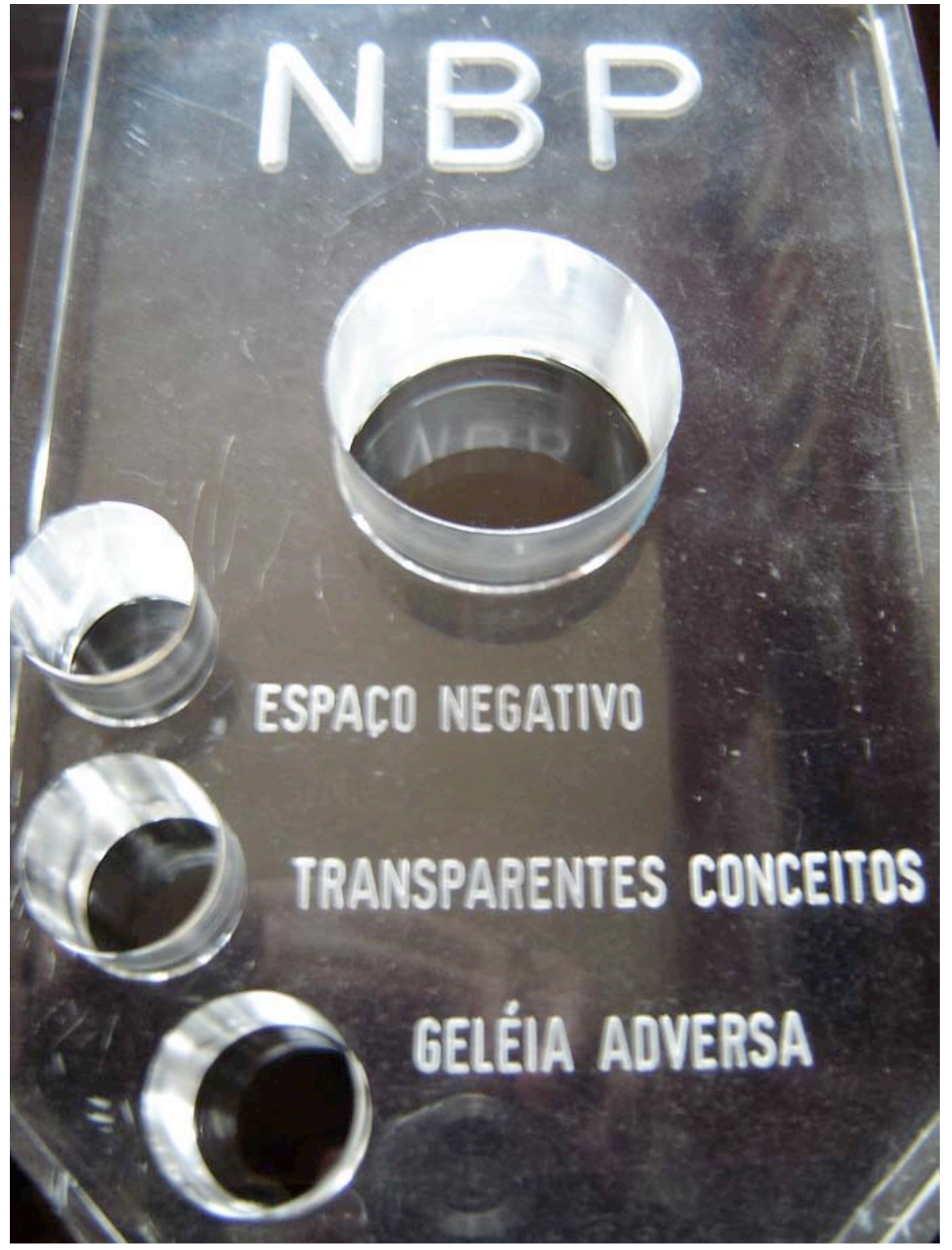

Figura 63 Ricardo Basbaum, objeto espaço negativo, 1998 


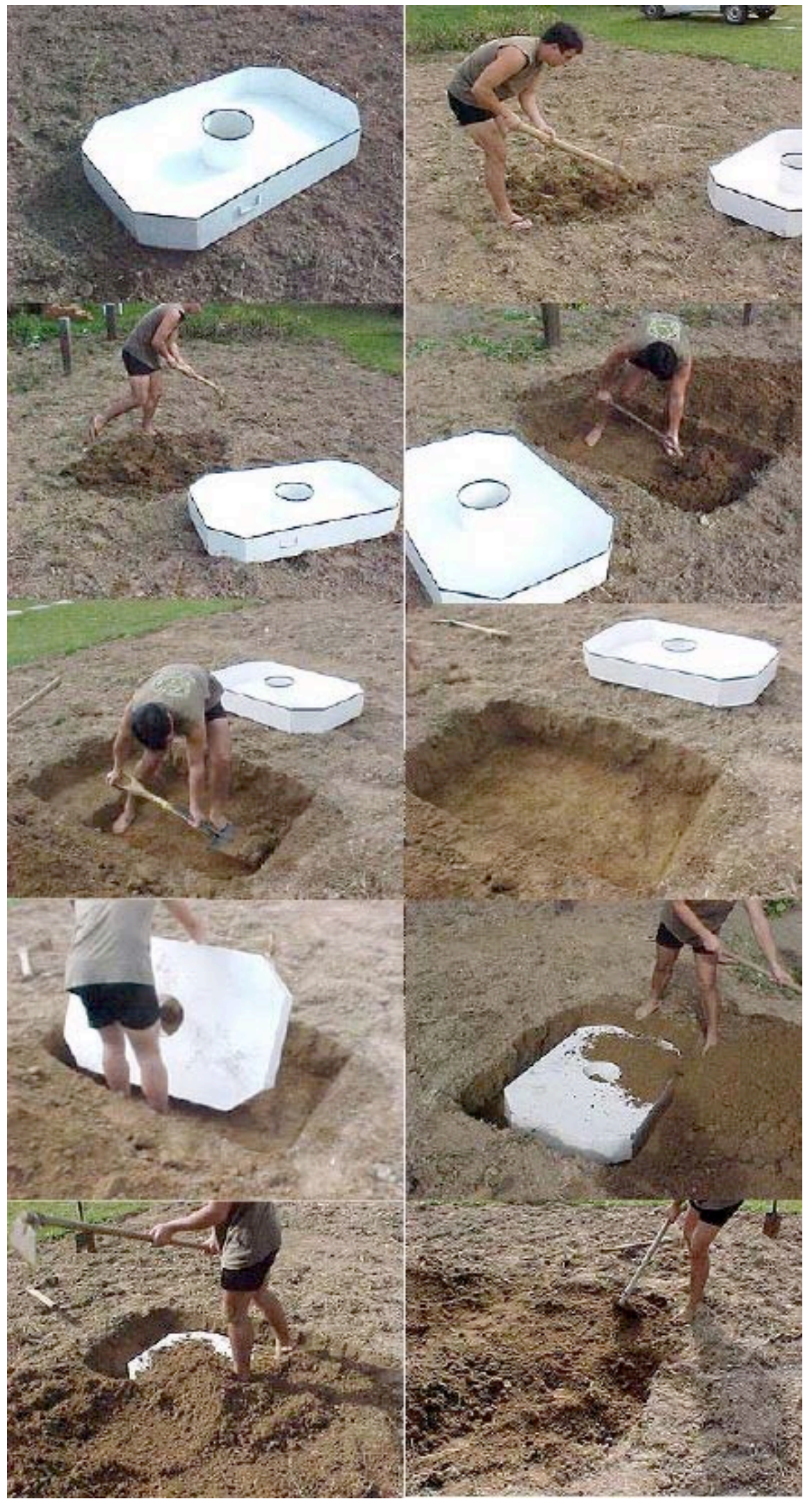

Figura 64 Ricardo Basbaum, Você gostaria de participar de uma experiência artística?, projeto em curso desde 1994

participação Jorge Menna Barreto, Porto Alegre, 2002 


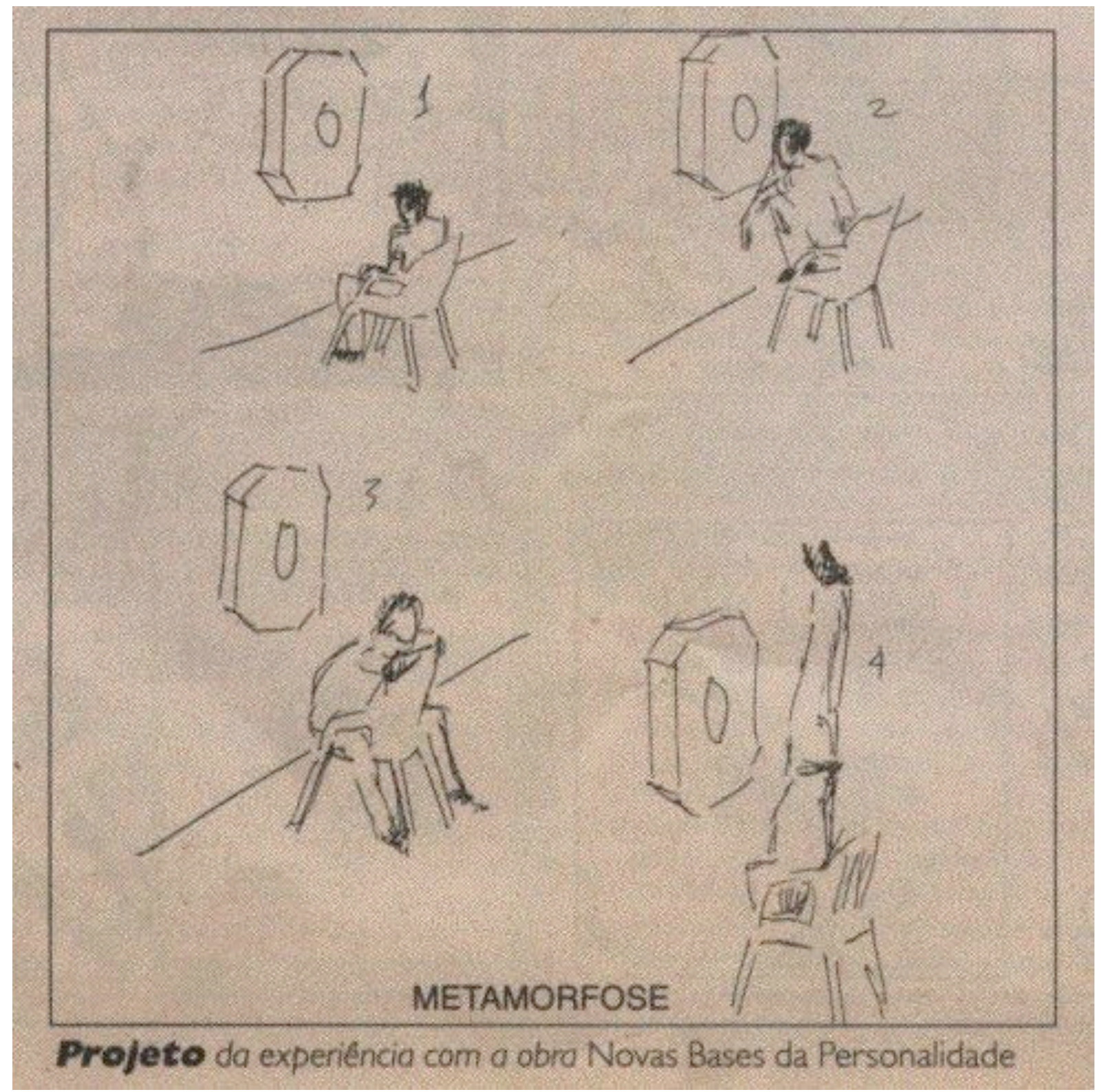

Figura 65 Ricardo Basbaum, Você gostaria de participar de uma experiência artística?, projeto em curso desde 1994

participação Enauro de Castro, Goiânia, 1999 


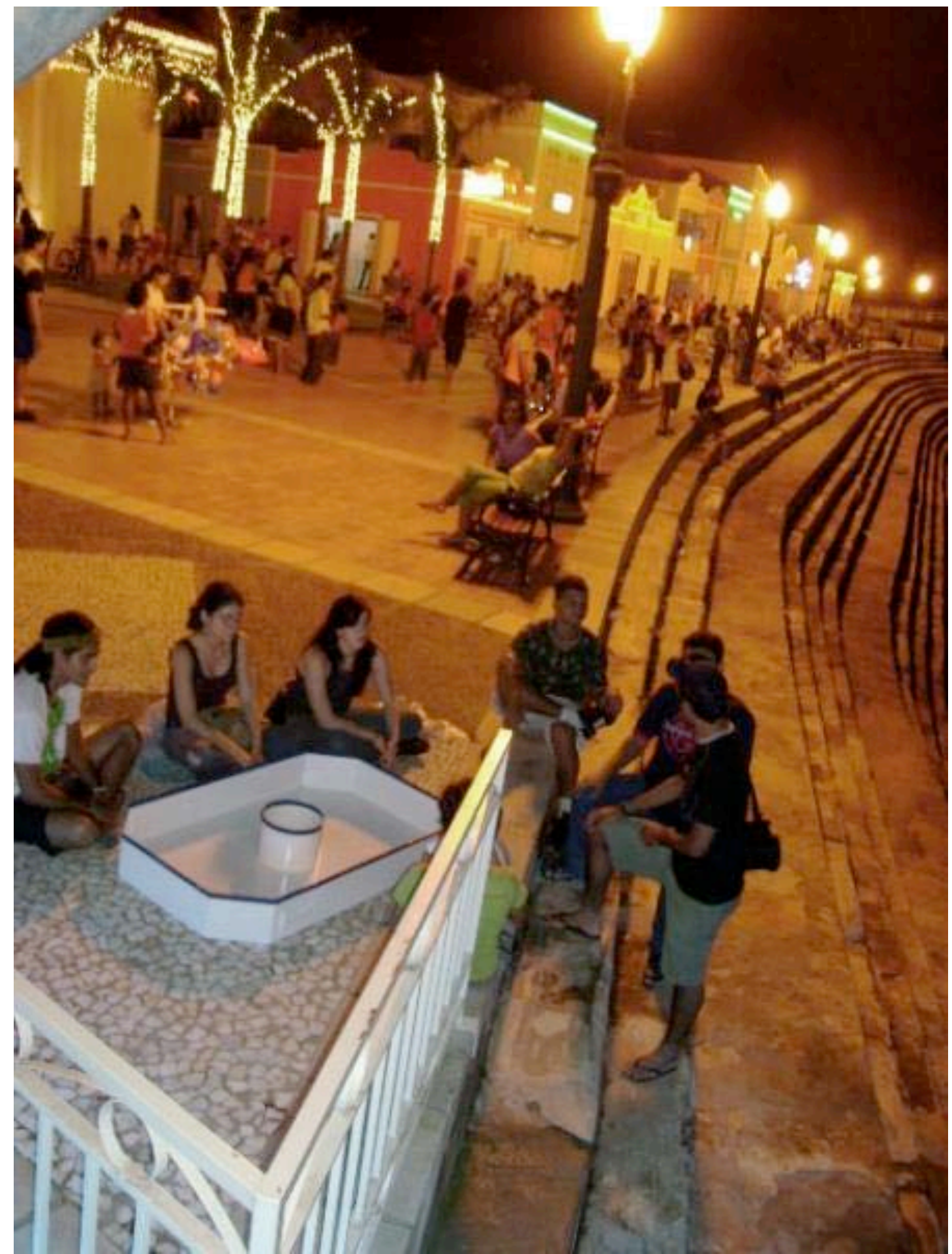

Figura 66 Ricardo Basbaum, Você gostaria de participar de uma experiência artística?, projeto em curso desde 1994

participação grupo Zukymavoy, Rio Branco, 2006 


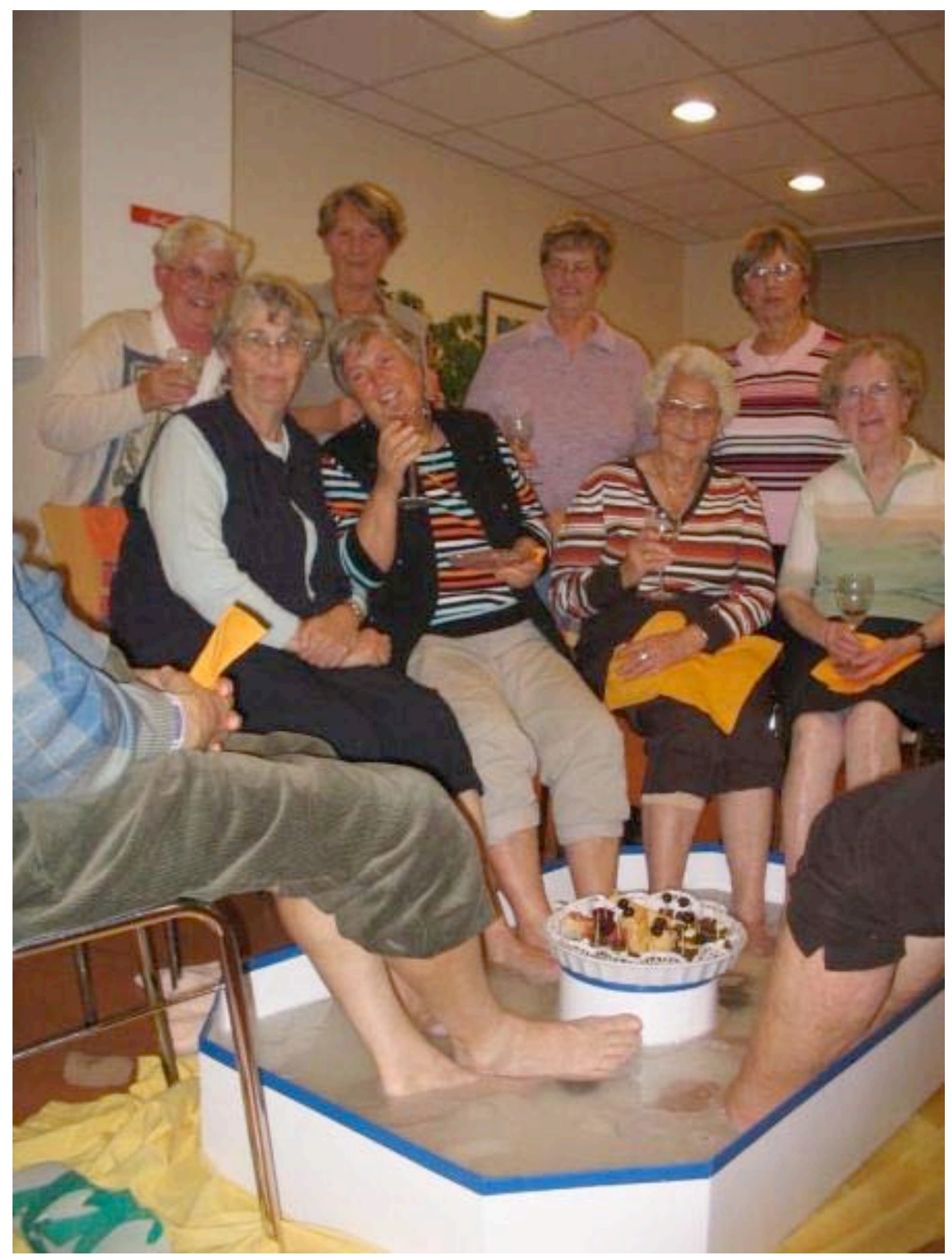

Figura 67 Ricardo Basbaum, Você gostaria de participar de uma experiência artística?, projeto em curso desde 1994

participação organização Hand in Hand, Kassel, Alemanha, 2006 


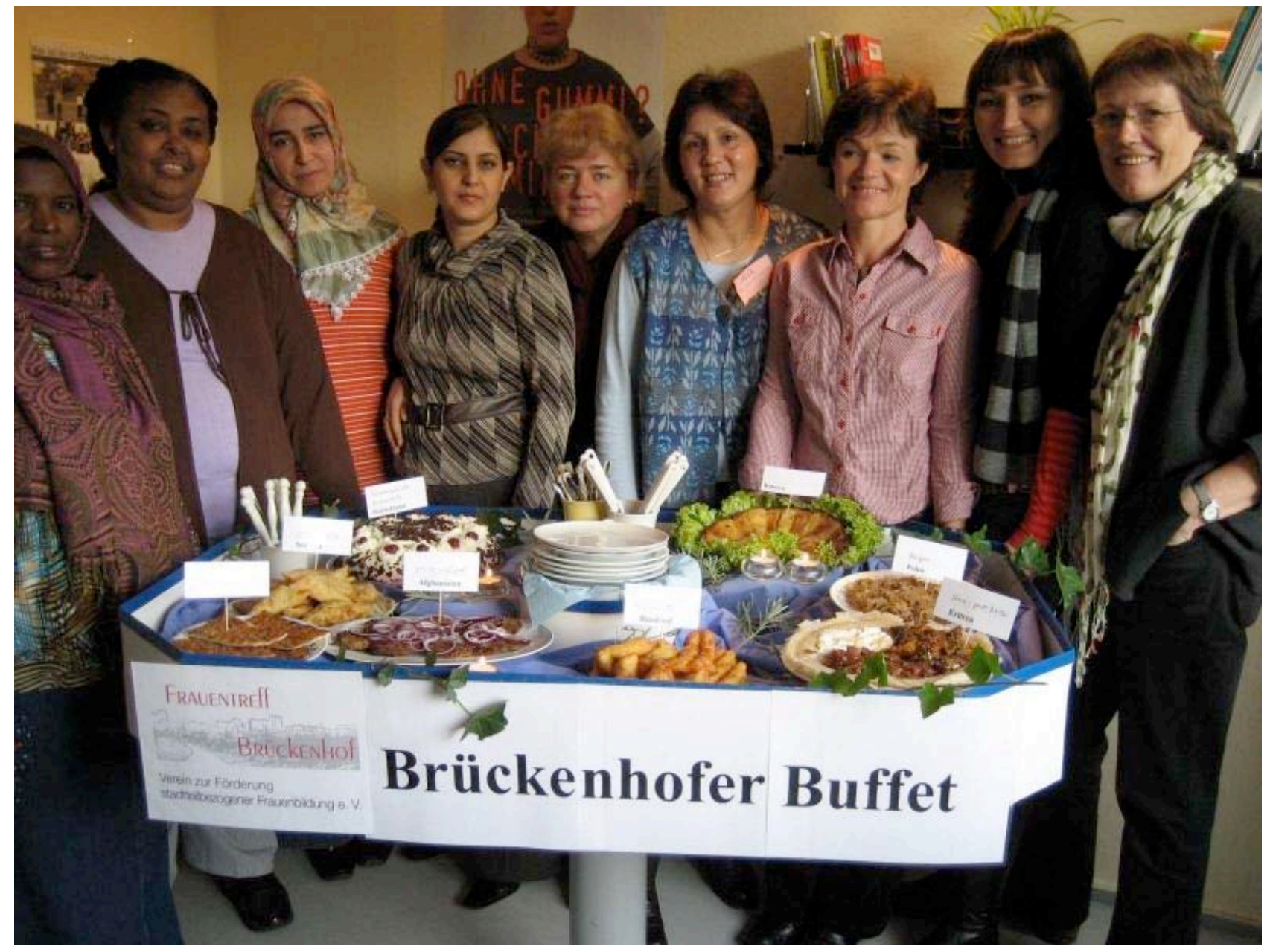

Figura 68 Ricardo Basbaum, Você gostaria de participar de uma experiência artística?, projeto em curso desde 1994

participação Karina Forst, Kassel, Alemanha, 2006 


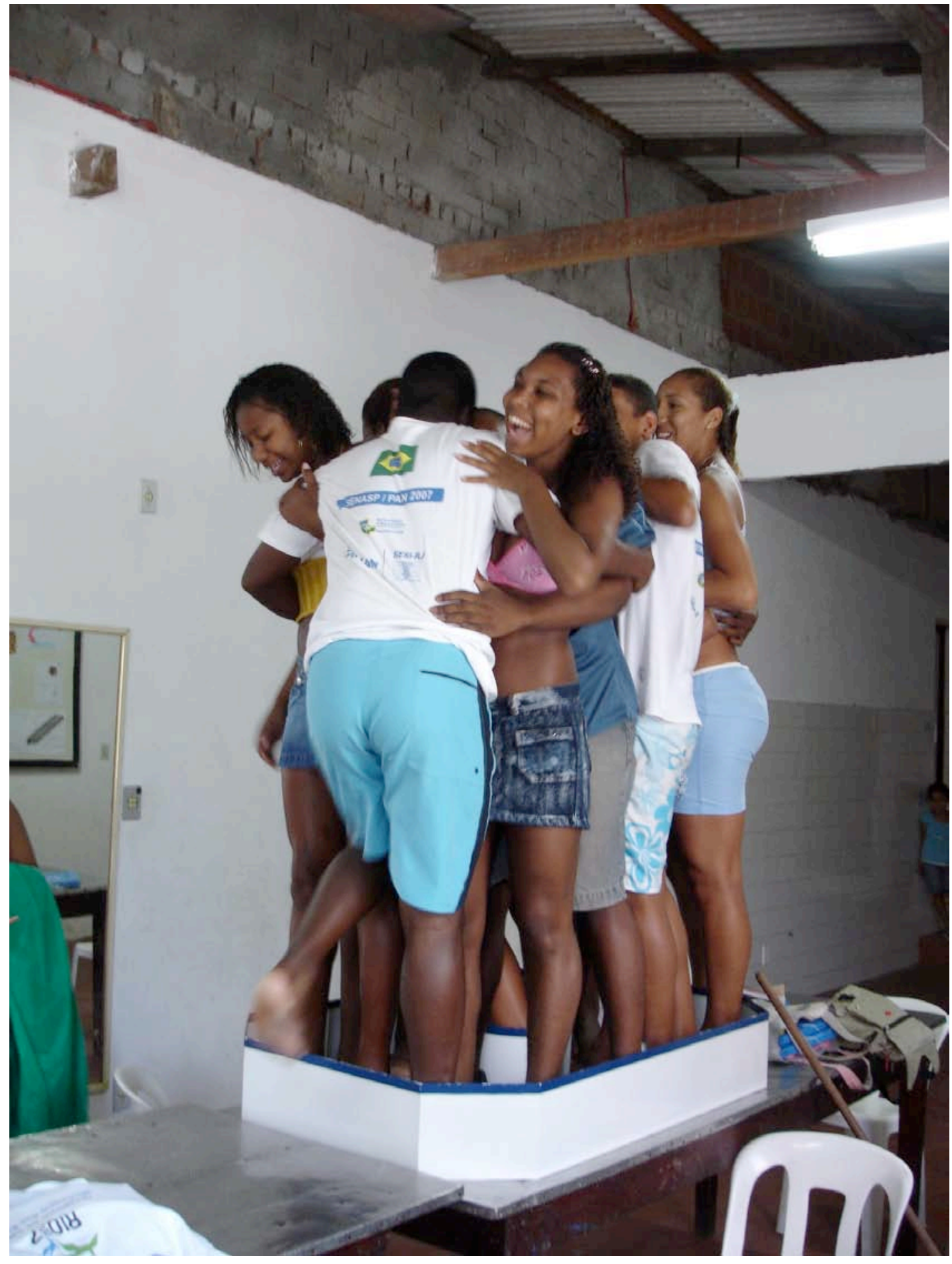

Figura 69 Ricardo Basbaum, Você gostaria de participar de uma experiência artística?, projeto em curso desde 1994

participação Casa das Artes da Mangueira, Rio de Janeiro, 2006 

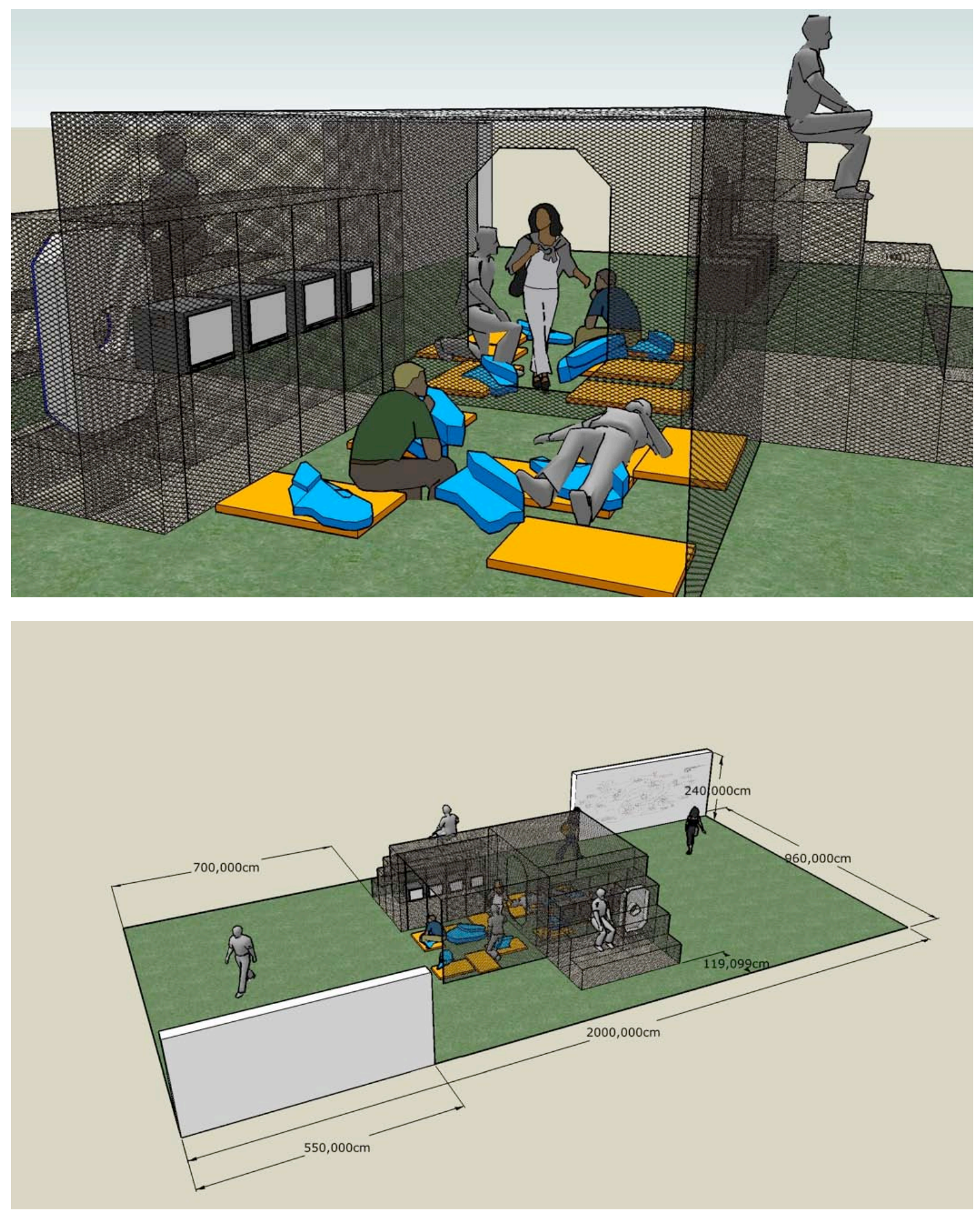

Figura 70 Ricardo Basbaum, Você gostaria de participar de uma experiência artística?, 2007 projeto de instalação para documenta 12 (estrutura arquitetônico-escultórica) 

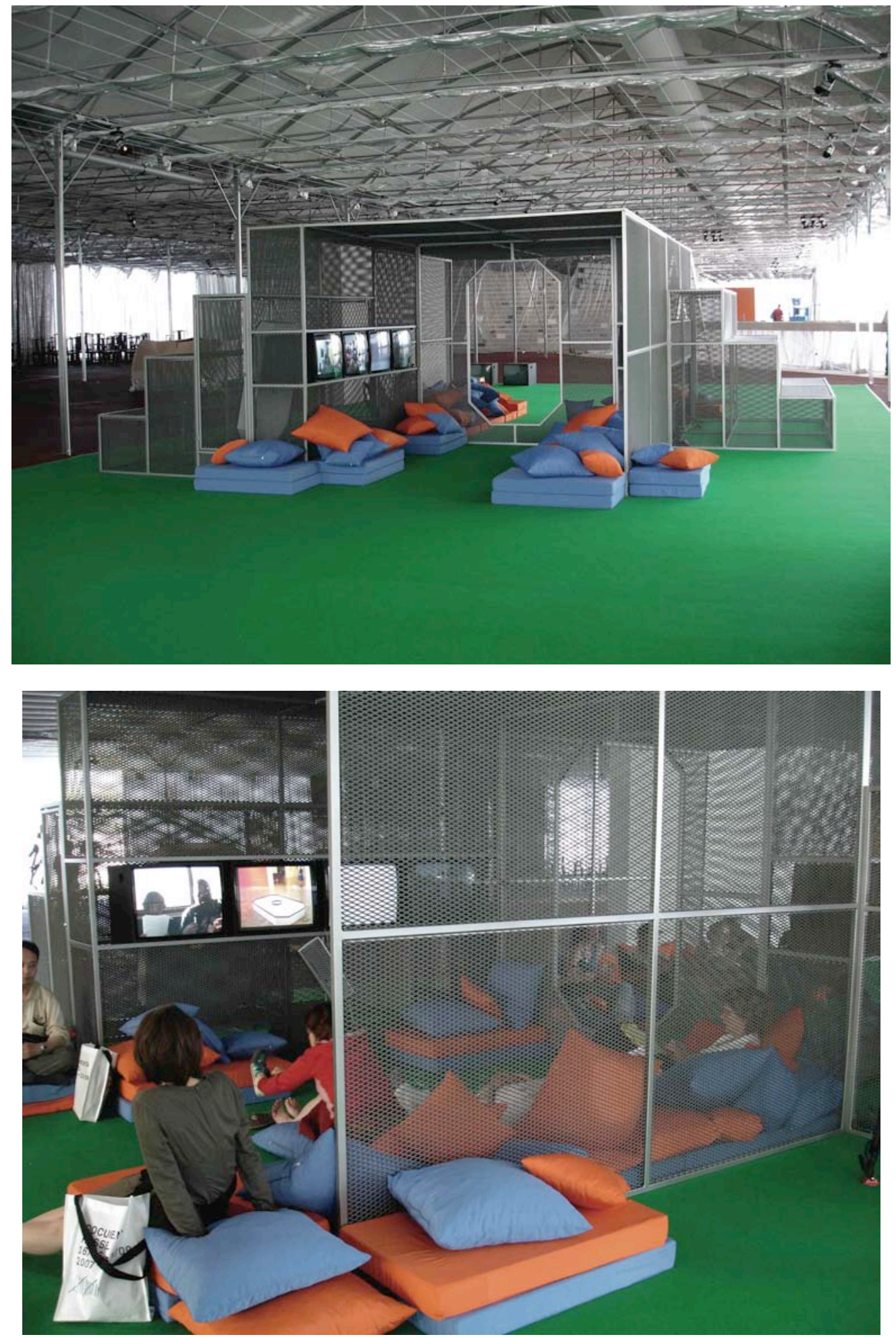

Figura 71 Ricardo Basbaum, Você gostaria de participar de uma experiência artística?, 2007 instalação para documenta 12

(estrutura arquitetônico-escultórica) 

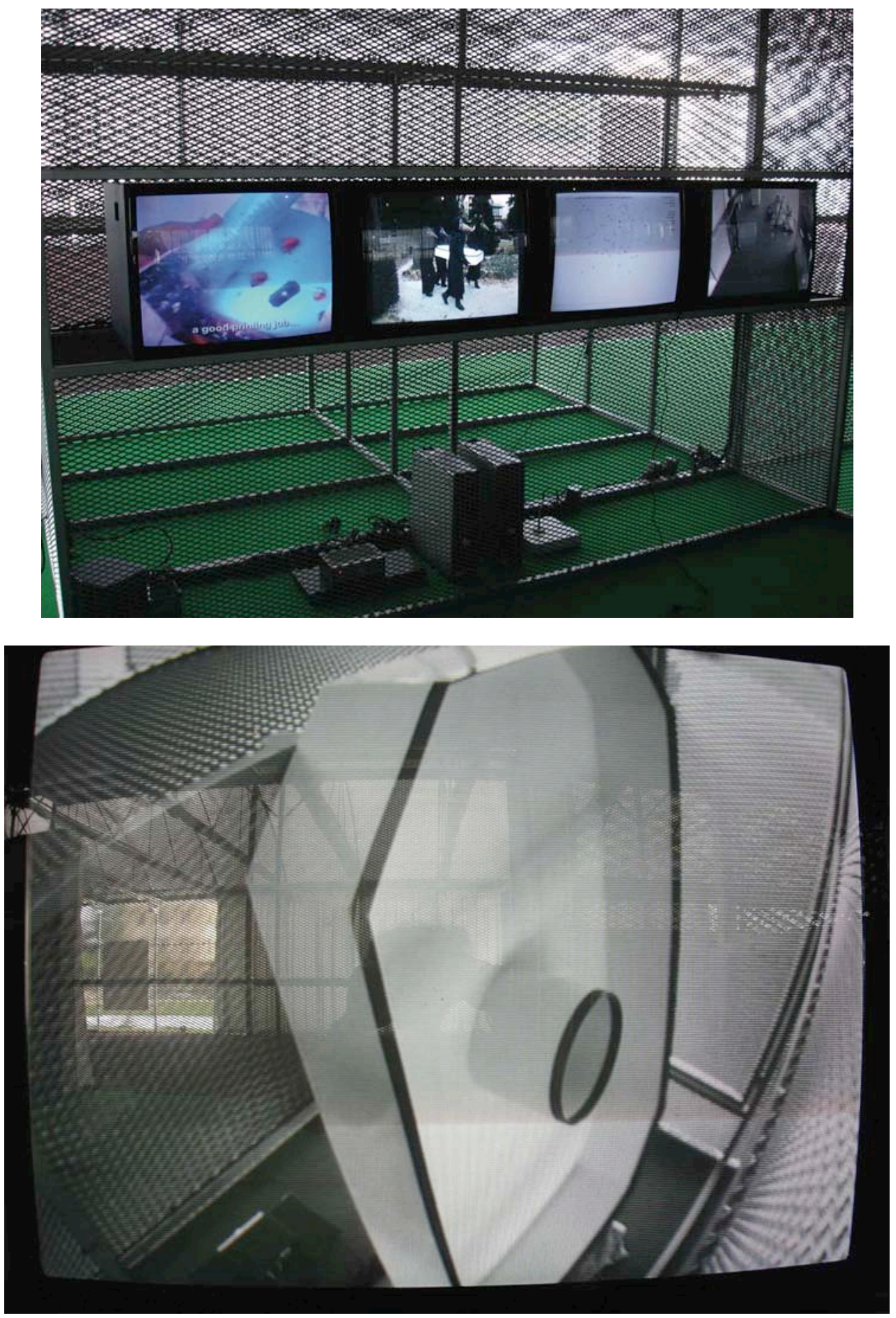

Figura 72 Ricardo Basbaum, Você gostaria de participar de uma experiência artística?, 2007 instalação para documenta 12 (estrutura arquitetônico-escultórica) 

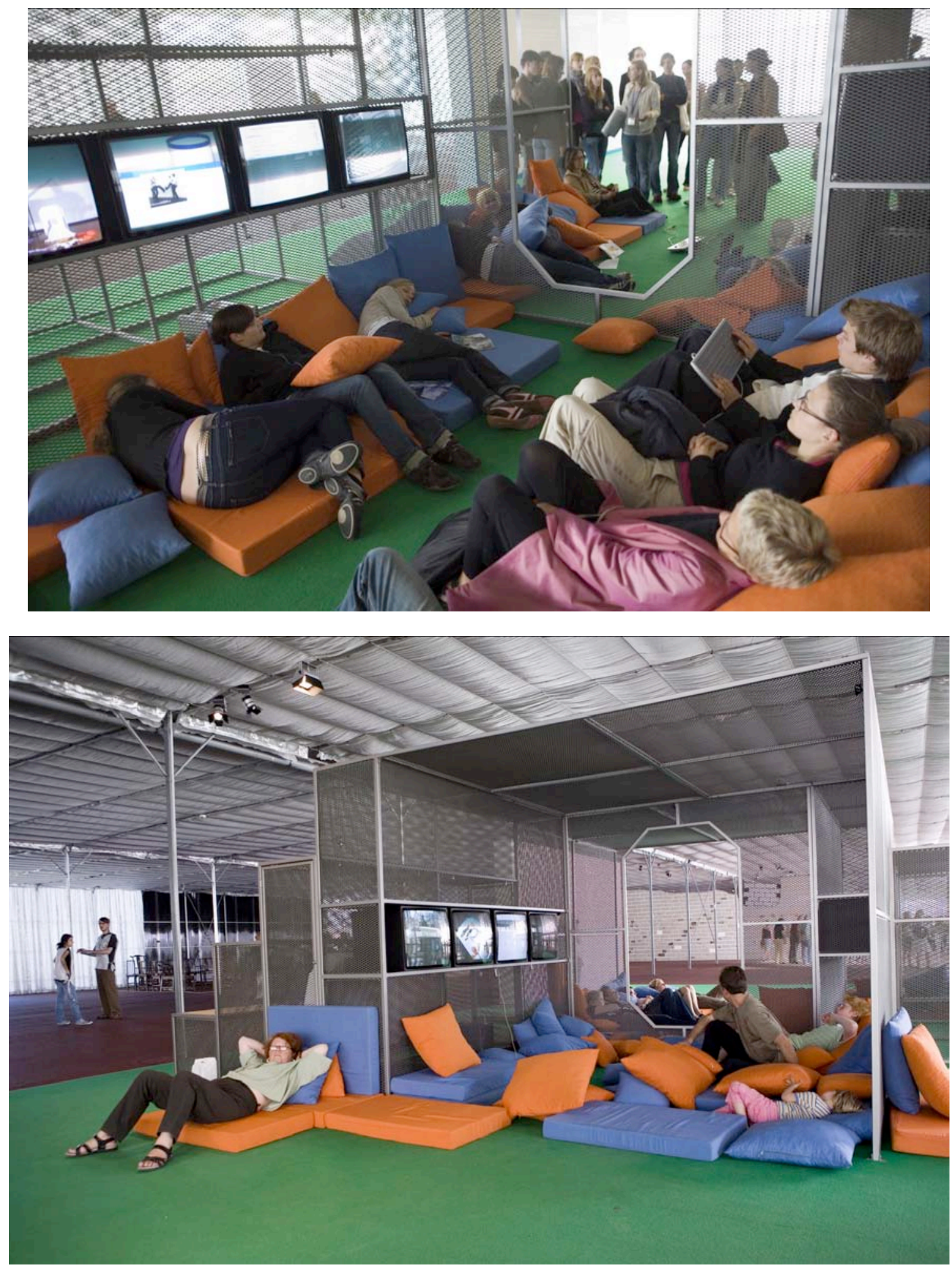

Figura 73 Ricardo Basbaum, Você gostaria de participar de uma experiência artística?, 2007 instalação para documenta 12 (estrutura arquitetônico-escultórica) 


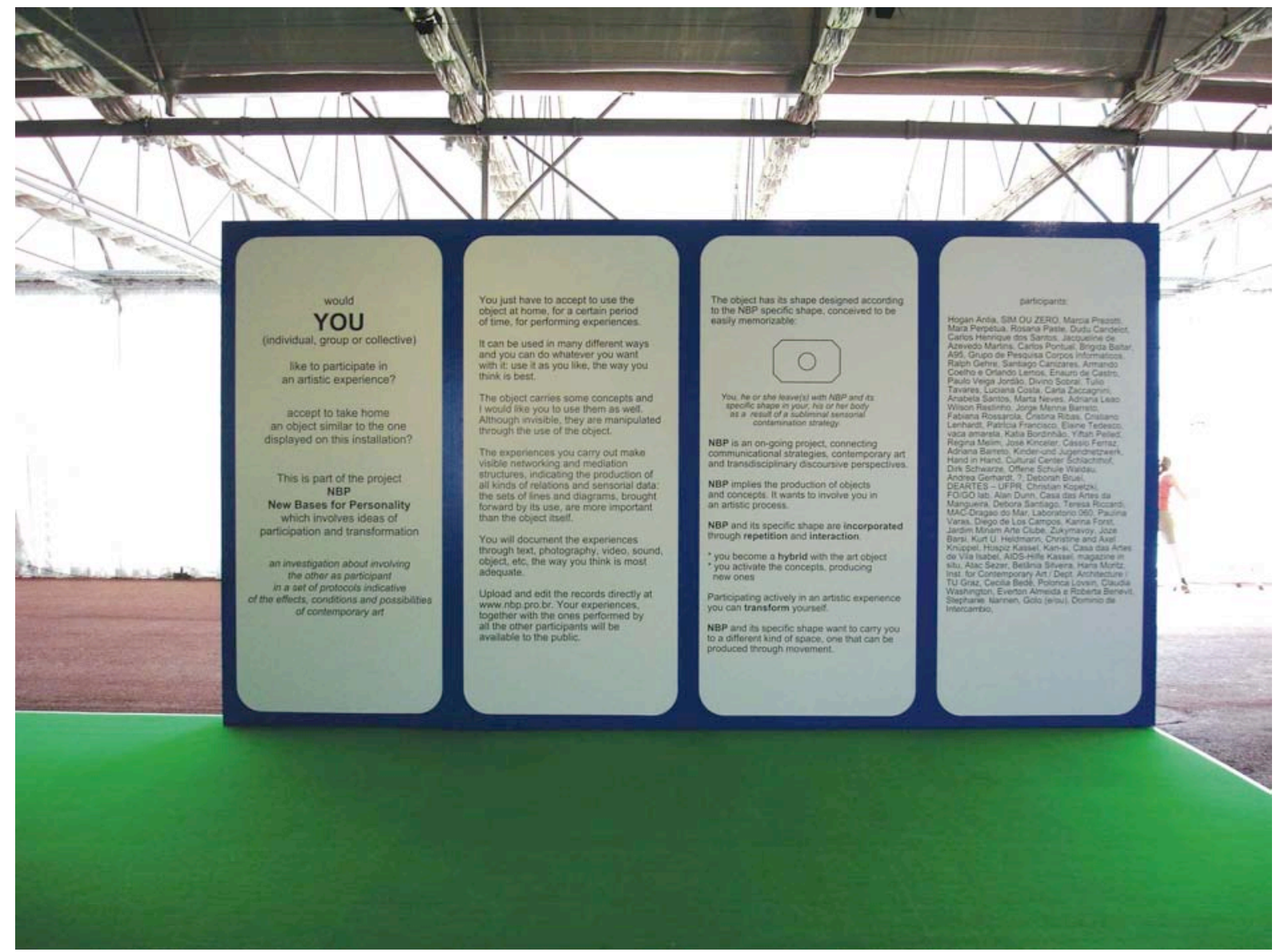

Figura 74 Ricardo Basbaum, Você gostaria de participar de uma experiência artística?, 2007 instalação para documenta 12

(estrutura arquitetônico-escultórica) 


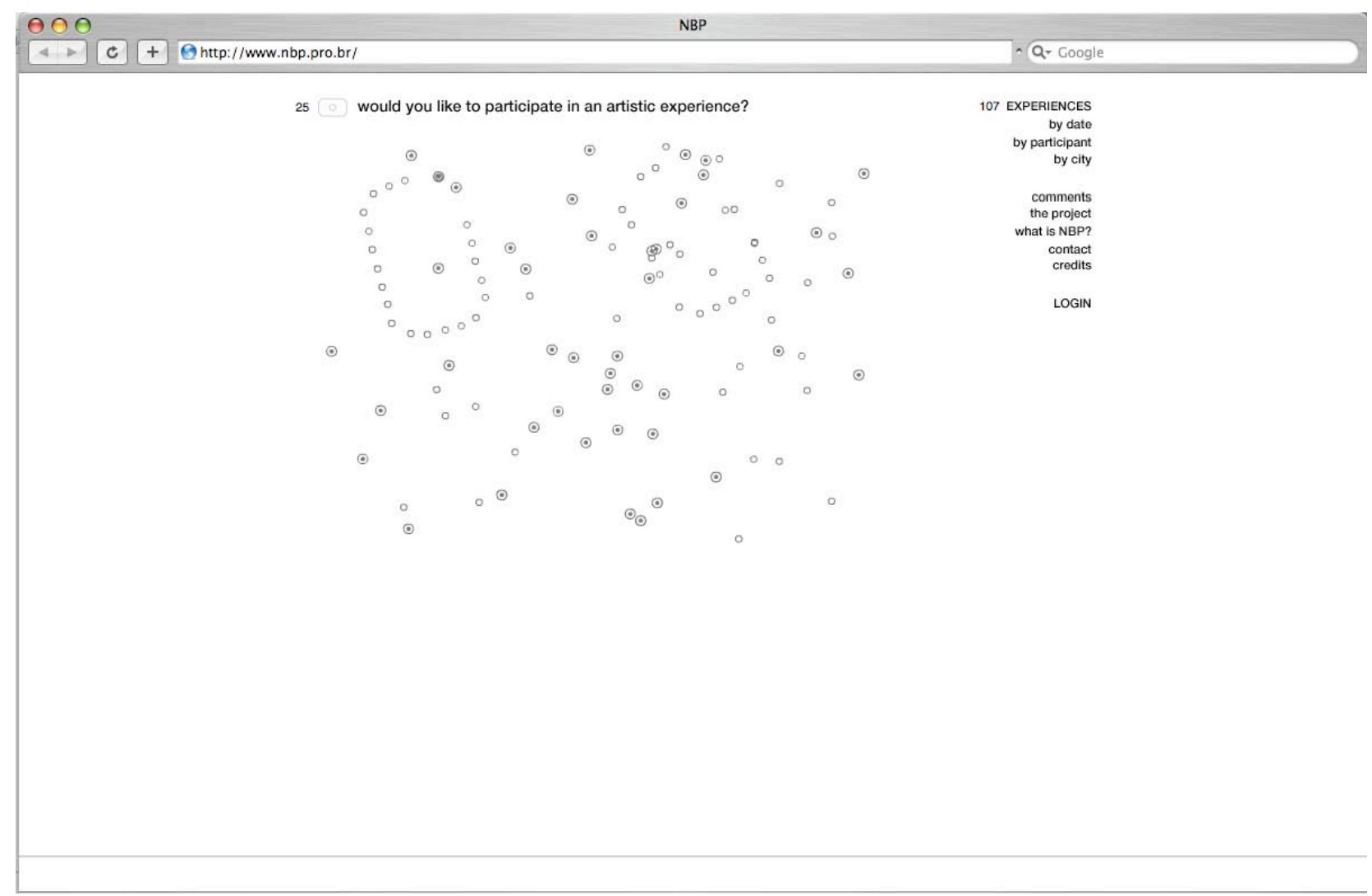

Figura 75 página de abertura do website do projeto Você gostaria de participar de uma experiência artística?

http://www.nbp.pro.br 


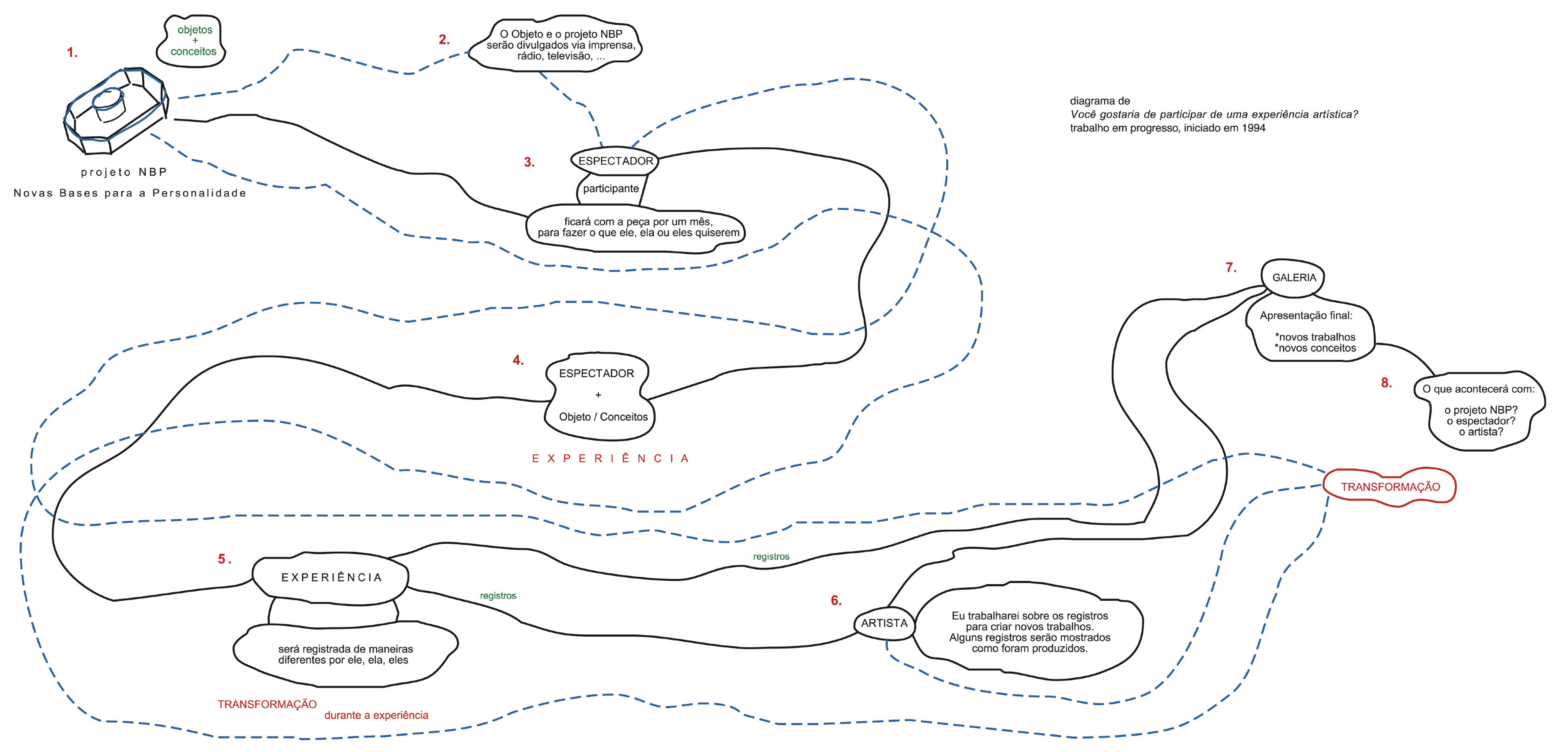

Figura 76 diagrama 01, 1994 


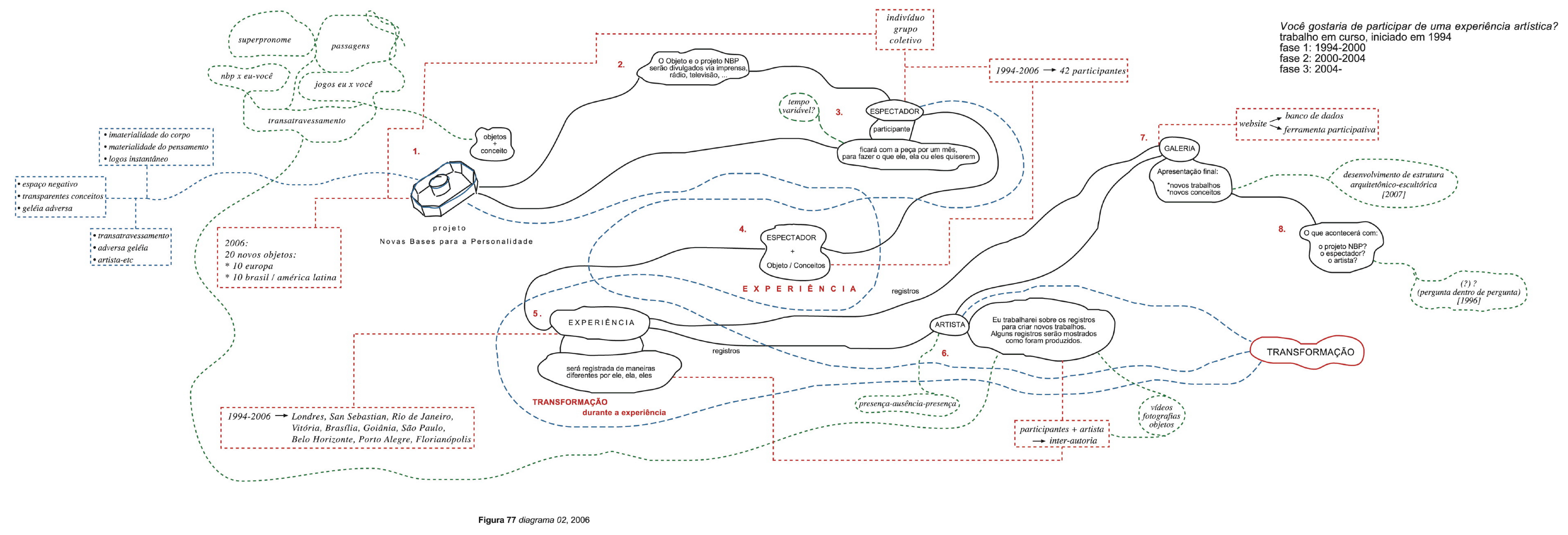




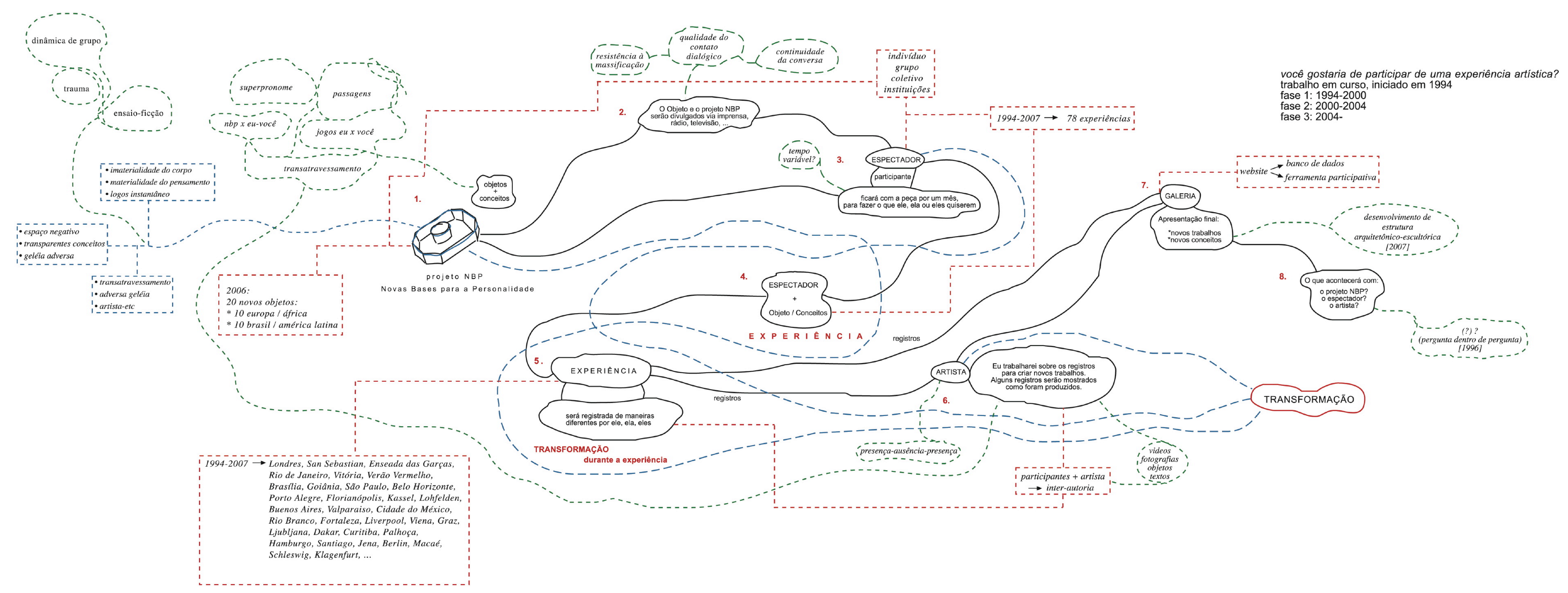

Figura 78 diagrama 03, 2007 


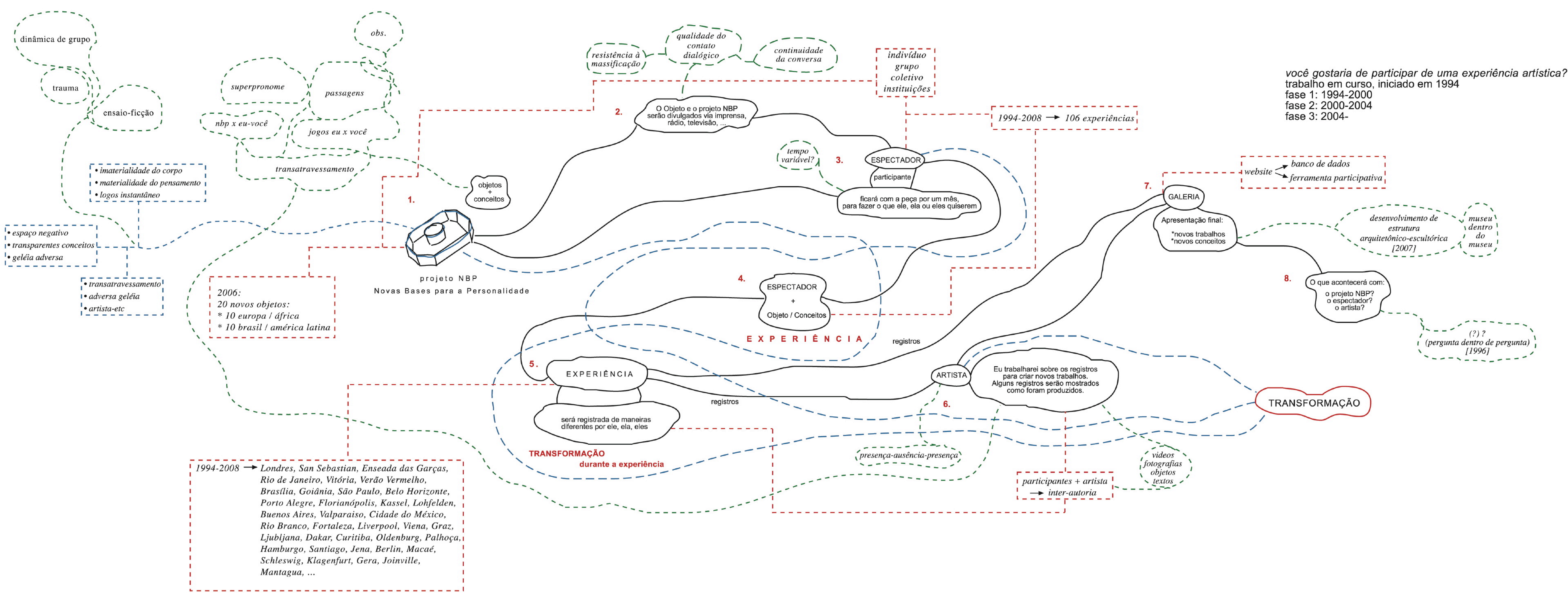

Figura 79 diagrama 04, 2008 


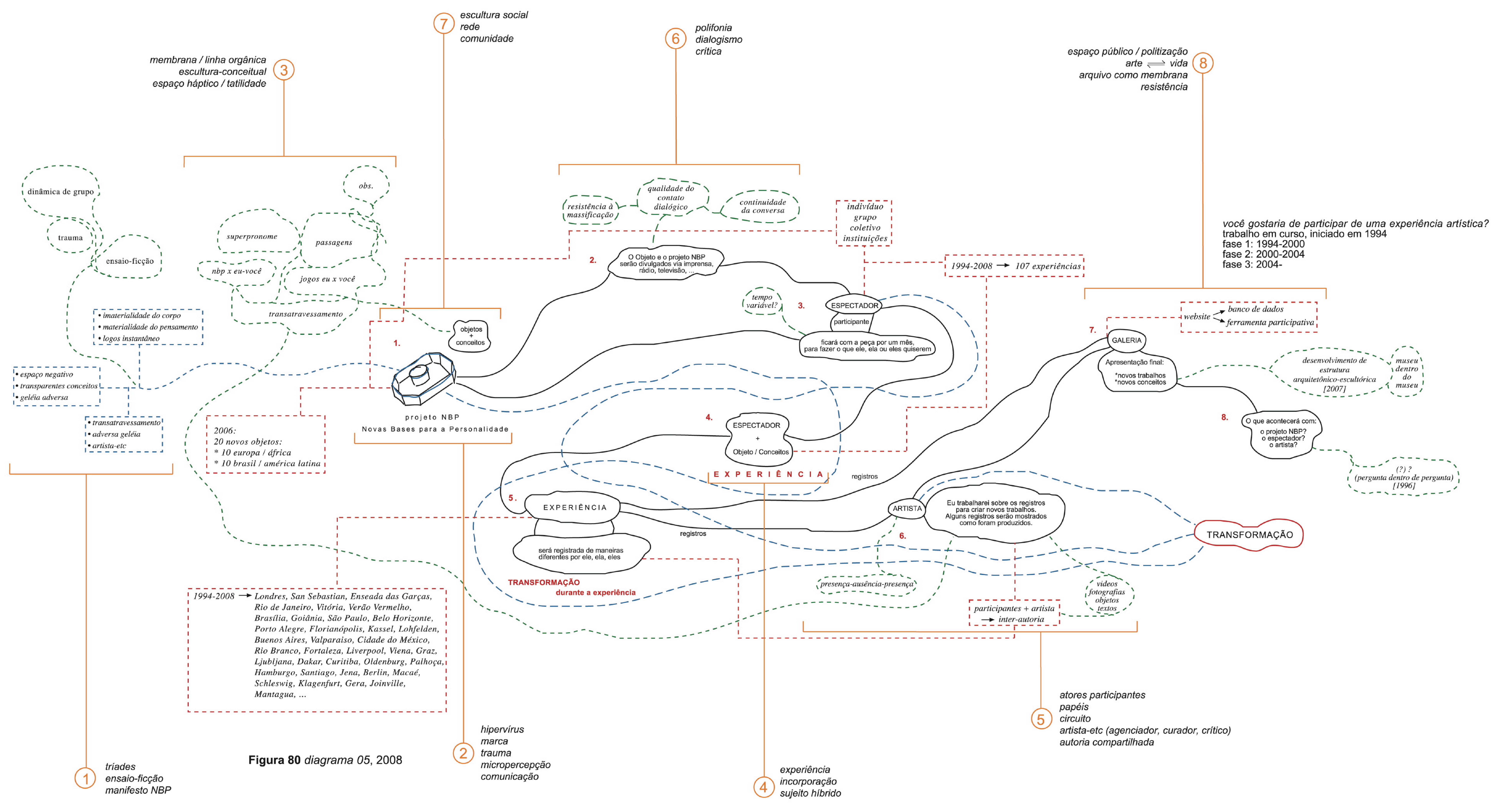

